Prepared in cooperation with the Kansas Water Office

\title{
Sediment Transport to and from Small Impoundments in Northeast Kansas, March 2009 through September 2011
}

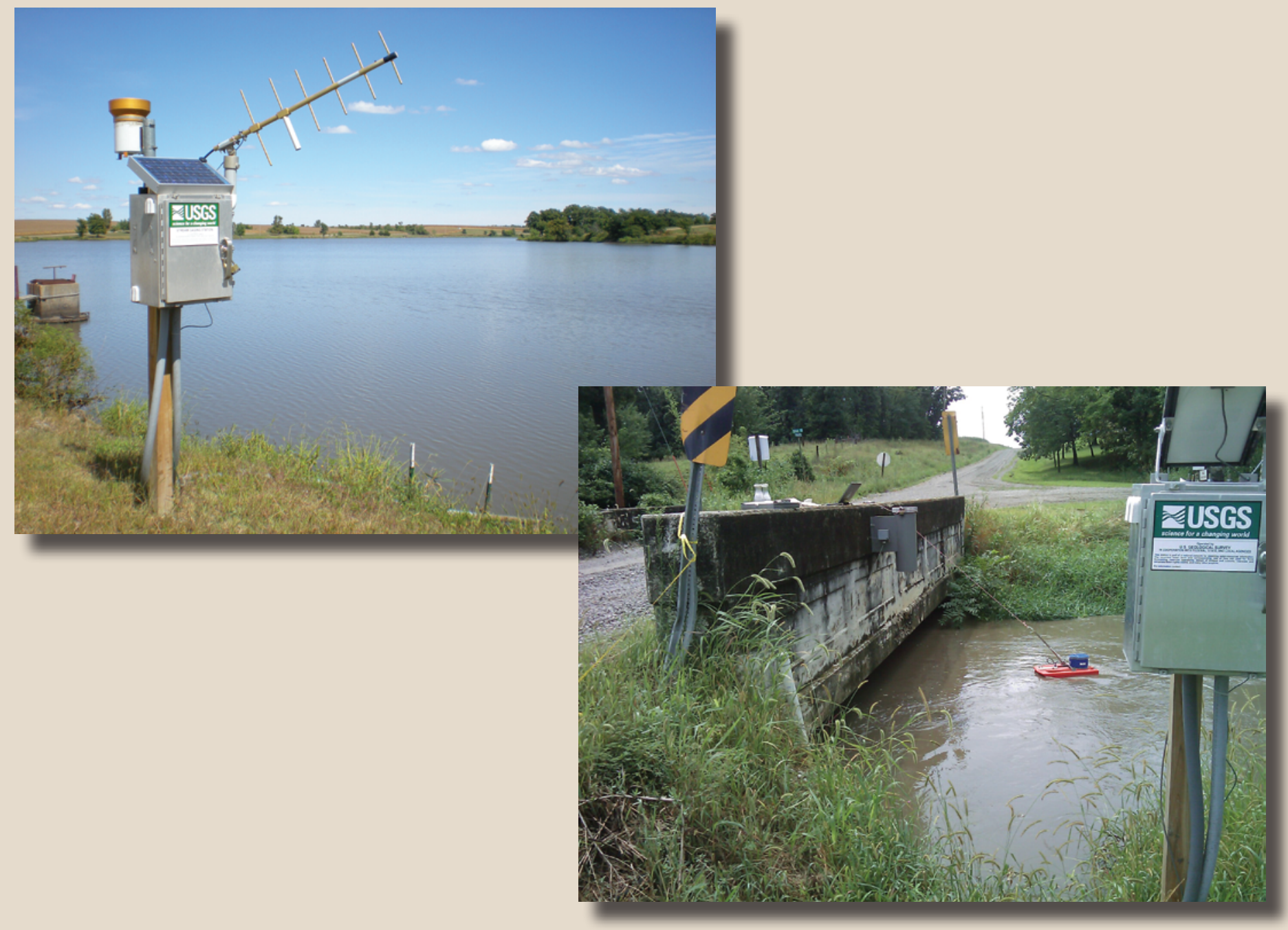

Scientific Investigations Report 2012-5269 
Cover. Upper photograph shows gagehouse and normal outflow structure at Atchison County Lake near Horton, Kansas (393806095273700). (Photograph by Eric Looper, U.S. Geological Survey, September 24, 2009). Lower photograph shows sediment sampling and discharge measurement during high flow at Clear Creek at Decatur Rd. near Horton, Kansas (393817095260100). (Photograph by Guy Foster, U.S. Geological Survey, August 17, 2009) 


\section{Sediment Transport to and from Small Impoundments in Northeast Kansas, March 2009 through September 2011}

By Guy M. Foster, Casey J. Lee, and Andrew C. Ziegler

Prepared in cooperation with the Kansas Water Office

Scientific Investigations Report 2012-5269 


\title{
U.S. Department of the Interior \\ KEN SALAZAR, Secretary \\ U.S. Geological Survey \\ Marcia K. McNutt, Director
}

\author{
U.S. Geological Survey, Reston, Virginia: 2012
}

For more information on the USGS - the Federal source for science about the Earth, its natural and living resources, natural hazards, and the environment, visit http://www.usgs.gov or call 1-888-ASK-USGS.

For an overview of USGS information products, including maps, imagery, and publications, visit http://www.usgs.gov/pubprod

To order this and other USGS information products, visit http://store.usgs.gov

Any use of trade, firm, or product names is for descriptive purposes only and does not imply endorsement by the U.S. Government.

Although this information product, for the most part, is in the public domain, it also may contain copyrighted materials as noted in the text. Permission to reproduce copyrighted items must be secured from the copyright owner.

Suggested citation:

Foster, G.M., Lee, C.J., and Ziegler, A.C., 2012, Sediment transport to and from small impoundments in northeast Kansas, March 2009 through September 2011: U.S. Geological Survey Scientific Investigations Report 2012-5269, 38 p. (Also available at http://pubs.usgs.gov/sir/2012/5269.) 


\section{Contents}

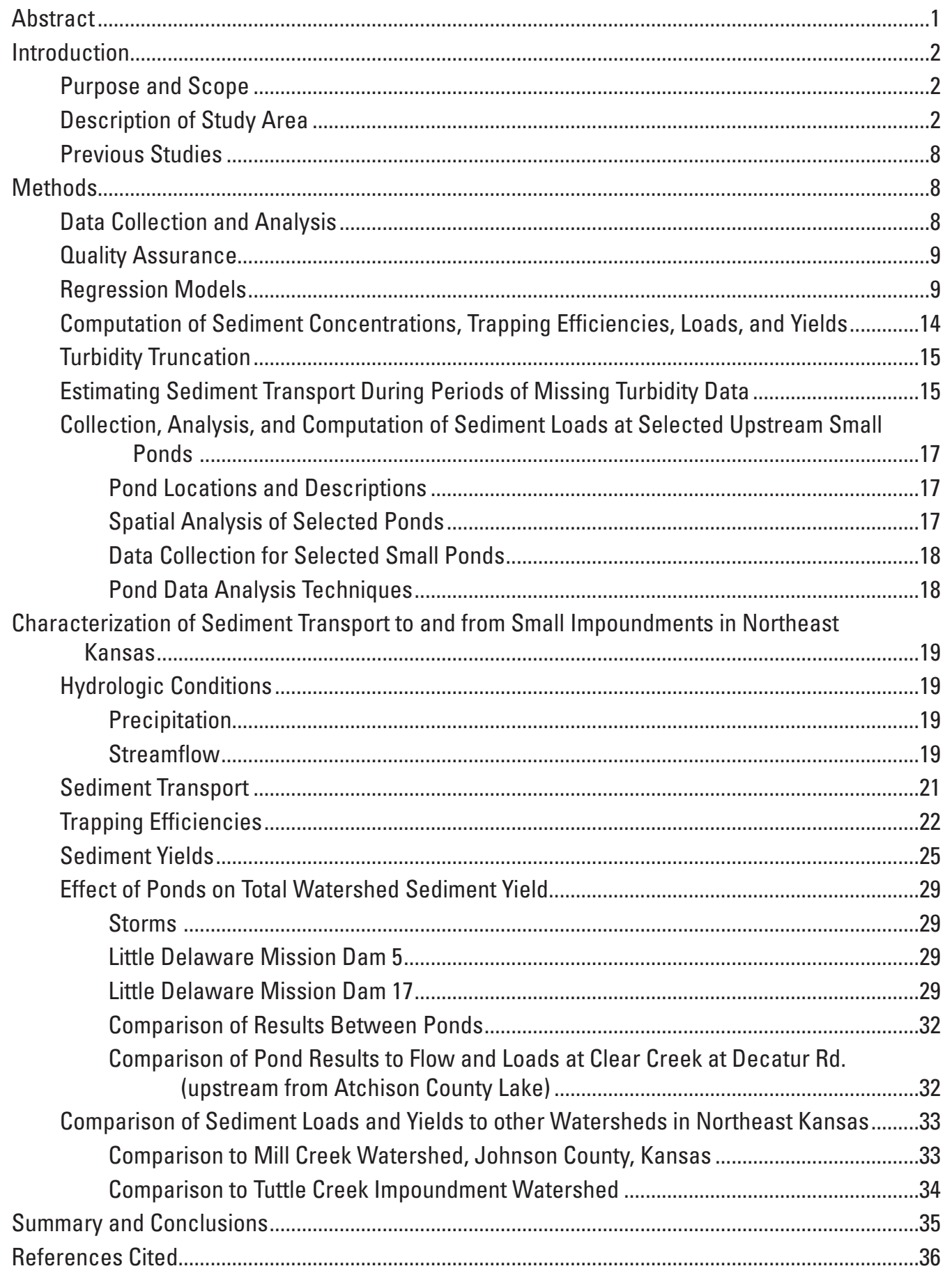




\section{Figures}

1. Map showing description of land use and location of study watersheds in northeast Kansas, 2009 through 2011.

2. Maps showing location of streamgages, sediment-sampling sites, watershed boundaries, National Inventory of Dams (NID) listed impoundments at $A$, Centralia Lake, B, Banner Creek Lake, and C, Atchison County Lake, 2009 through 2011 overlaid over 2010 aerial imagery.

3. Graph showing longitudinal profiles of streams upstream from study impoundments in northeast Kansas.

4. Graphs showing relation between cross-sectional mean (or independent reading in the case of the lakes) and in-place turbidity readings at study sites during March 2009 through September 2011.

5. Graphs showing comparison of measured and model-estimated suspendedsediment concentrations for the multiple linear regression at Clear Creek at Decatur Rd. (upstream from Atchison County Lake), and single linear regression relations between turbidity and suspended-sediment concentrations with removed outliers in red for other sediment sampling sites during March 2009 through September 2011...

6. Graphs showing relations between discharge and suspended-sediment concentration at study sites with removed outliers in red (if removed from turbidity models, also removed from streamflow models) during March 2009 through September 2011.

7. Example hydrograph from Black Vermillion River above Centralia Lake showing differences between discharge- and turbidity-computed models, shifting results (Porterfield, 1972), and difference in prediction intervals between models during May 25-26, 2011.

8. Graph showing percent of time each regression model was used and percent of total load computed by each model for each site during March 2009 through September 2011

9. Bar graph showing annual precipitation totals recorded by National Weather Service meteorological monitoring stations.

10. Bar graph showing computed and estimated streamflow into and from each lake for study period during March 2009 through September 2011

11. Graph showing streamflow duration curves for study sites upstream from lakes during March 2009 through September 2011.

12. Bar graph showing computed and estimated sediment transport into and from each lake for study period during March 2009 through September 2011

13. Graph showing suspended-sediment load duration curves for study sites upstream from lakes during March 2009 through September 2011

14. Pie charts showing total and mean annual trapping efficiencies and loads into and from each study lake during March 2009 through September 2011.

15. Graph showing total and mean annual sediment yield and streamflow and corresponding depth of runoff for study period during March 2009 through September 2011 ...

16. Graphs showing stormflow and suspended-sediment concentration hydrographs for Little Delaware Mission Dam (LDMD) 5 (A-E) and LDMD 17 (F-J) for each storm (rainfall totals recorded by National Weather Service (NWS) Weather Station at Horton, Kansas), April through August 2011 
17. Bar graph showing difference in sediment loads with and without the two small study ponds on total watershed sediment transport (during the five observed storms), and extrapolated during entire watershed and all four National Inventory of Dams listed

ponds during April through August 2011.

18. Bar graphs showing comparison of mean annual sediment yield and streamflow yield with study watersheds and sub-watersheds in the Mill Creek Watershed, Johnson County, Kansas, and the Tuttle Creek lake watershed.

\section{Tables}

1. Location and contributing drainage area of streamgages and sediment-sampling stations in Atchison, Jackson, and Nemaha counties in northeast Kansas during March 2009 through September 2011.

2. Land use and sediment management practices upstream from sediment-sampling stations in northeast Kansas, obtained from on-site surveys, 2009.....

3. Recent historical land use upstream from streamgages and sediment-sampling stations in northeast Kansas during March 2009 through September 2011

4. Regression models and summary statistics for suspended-sediment concentration computations at study sites during March 2009 through September 2011 .....................13

5. Turbidity truncation at study sites during March 2009 through September 2011 ............15

6. Location and contributing drainage area of small pond gaging sites in the Atchison watershed, northeast Kansas during March 2009 through September 2011

7. Suspended-sediment concentration and percent silt/clay (<63 micrometers diameter) from discrete samples collected from study sites during March 2009 through September 2011

8. Stormflows, sediment transport, trapping efficiencies, and sediment yields for study ponds Little Delaware Mission Dam (LDMD) 5 and LDMD 17 (rainfall totals recorded by National Weather Service Weather Station at Horton, Kansas) from April through August 2011

9. Comparison of sediment loads between small study ponds Little Delaware Mission Dam (LDMD) 5 and LDMD 17, and Clear Creek at Decator Rd. (upstream from Atchison County Lake) during April through August 2011 


\section{Conversion Factors and Datum}

Inch/Pound to SI

\begin{tabular}{|c|c|c|}
\hline Multiply & By & To obtain \\
\hline \multicolumn{3}{|c|}{ Length } \\
\hline centimeter $(\mathrm{cm})$ & 0.3937 & inch (in.) \\
\hline inch (in.) & 2.54 & centimeter $(\mathrm{cm})$ \\
\hline foot $(\mathrm{ft})$ & 0.3048 & $\operatorname{meter}(\mathrm{m})$ \\
\hline micrometer $(\mu \mathrm{m})$ & 0.00003937 & inch (in.) \\
\hline mile (mi) & 1.609 & kilometer $(\mathrm{km})$ \\
\hline \multicolumn{3}{|c|}{ Area } \\
\hline acre & 4,047 & square meter $\left(\mathrm{m}^{2}\right)$ \\
\hline square mile $\left(\mathrm{mi}^{2}\right)$ & 2.590 & square kilometer $\left(\mathrm{km}^{2}\right)$ \\
\hline \multicolumn{3}{|c|}{ Volume } \\
\hline acre-foot (acre-ft) & 1,233 & cubic meter $\left(\mathrm{m}^{3}\right)$ \\
\hline gallon (gal) & 3.785 & liter $(\mathrm{L})$ \\
\hline gallon (gal) & 0.003785 & cubic meter $\left(\mathrm{m}^{3}\right)$ \\
\hline \multicolumn{3}{|c|}{ Flow } \\
\hline cubic foot per second $\left(\mathrm{ft}^{3} / \mathrm{s}\right)$ & 0.02832 & cubic meter per second $\left(\mathrm{m}^{3} / \mathrm{s}\right)$ \\
\hline cubic foot per second $\left(\mathrm{ft}^{3} / \mathrm{s}\right)$ & 1.9835 & acre-feet per day (acre-ft/d) \\
\hline foot per mile ( $\mathrm{ft} / \mathrm{mi})$ & 0.1894 & meter per kilometer $(\mathrm{m} / \mathrm{km})$ \\
\hline million gallons per day (Mgal/d) & 0.04381 & cubic meter per second $\left(\mathrm{m}^{3} / \mathrm{s}\right)$ \\
\hline \multicolumn{3}{|c|}{ Rate } \\
\hline acre-foot per square mile (acre-ft/mi²) & 476.1 & cubic meter per square kilometer $\left(\mathrm{m}^{3} / \mathrm{km}^{2}\right)$ \\
\hline inch per hour (in/hr) & 25.40 & millimeter per hour $(\mathrm{mm} / \mathrm{hr})$ \\
\hline \multicolumn{3}{|c|}{ Weight } \\
\hline $\operatorname{gram}(\mathrm{g})$ & 453.6 & pound (lb) \\
\hline pound per second $(\mathrm{lb} / \mathrm{s})$ & 43.2 & ton per day (ton/d) \\
\hline ton & 2,000 & pound (lb) \\
\hline \multicolumn{3}{|c|}{ Yield } \\
\hline ton per square mile (ton $/ \mathrm{mi}^{2}$ ) & 0.3503 & tonne per square kilometer (tonne $/ \mathrm{km}^{2}$ ) \\
\hline
\end{tabular}

Temperature can be converted to degrees Celsius $\left({ }^{\circ} \mathrm{C}\right)$ or degrees Fahrenheit $\left({ }^{\circ} \mathrm{F}\right)$ by the equations:

$$
\begin{aligned}
& { }^{\circ} \mathrm{C}=5 / 9\left({ }^{\circ} \mathrm{F}-32\right) \\
& { }^{\circ} \mathrm{F}=9 / 5\left({ }^{\circ} \mathrm{C}\right)+32
\end{aligned}
$$

Vertical coordinate information is referenced to North American Vertical Datum of 1988 (NAVD 88).

Horizontal coordinate information is referenced to North American Datum of 1983 (NAD 83).

Altitude, as used in this report, refers to distance above the vertical datum.

Suspended-sediment concentrations are report in milligrams per liter $(\mathrm{mg} / \mathrm{L})$.

Sediment loads are reported in tons. 


\title{
Sediment Transport to and from Small Impoundments in Northeast Kansas, March 2009 through September 2011
}

\author{
By Guy M. Foster, Casey J. Lee, and Andrew C. Ziegler
}

\section{Abstract}

The U.S. Geological Survey, in cooperation with the Kansas Water Office, investigated sediment transport to and from three small impoundments (average surface area of 0.1 to 0.8 square miles) in northeast Kansas during March 2009 through September 2011. Streamgages and continuous turbidity sensors were operated upstream and downstream from Atchison County, Banner Creek, and Centralia Lakes to study the effect of varied watershed characteristics and agricultural practices on sediment transport in small watersheds in northeast Kansas. Atchison County Lake is located in a predominantly agricultural basin of row crops, with wide riparian buffers along streams, a substantial amount of tile drainage, and numerous small impoundments (less than 0.05 square miles; hereafter referred to as "ponds"). Banner Creek Lake is a predominantly grassland basin with numerous small ponds located in the watershed, and wide riparian buffers along streams. Centralia Lake is a predominantly agricultural basin of row crops with few ponds, few riparian buffers along streams, and minimal tile drainage. Upstream from Atchison County, Banner Creek, and Centralia Lakes 24, 38, and 32 percent, respectively, of the total load was transported during less than 0.1 percent (approximately 0.9 days) of the time. Despite less streamflow in 2011, larger sediment loads during that year indicate that not all storm events transport the same amount of sediment; larger, extreme storms during the spring may transport much larger sediment loads in small Kansas watersheds. Annual sediment yields were 360, 400, and 970 tons per square mile per year at Atchison County, Banner, and Centralia Lake watersheds, respectively, which were less than estimated yields for this area of Kansas (between 2,000 and 5,000 tons per square mile per year). Although Centralia and Atchison County Lakes had similar percentages of agricultural land use, mean annual sediment yields upstream from Centralia Lake were about 2.7 times those at Atchison County or Banner Creek Lakes. These data indicate larger yields of sediment from watersheds with row crops and those with fewer small ponds, and smaller yields in watersheds which are primarily grassland, or agricultural with substantial tile drainage and riparian buffers along streams. These results also indicated that a cultivated watershed can produce yields similar to those observed under the assumed reference (or natural) condition. Selected small ponds were studied in the Atchison County Lake watershed to characterize the role of small ponds in sediment trapping. Studied ponds trapped about 8 percent of the sediment upstream from the sediment-sampling site. When these results were extrapolated to the other ponds in the watershed, differences in the extent of these ponds was not the primary factor affecting differences in yields among the three watersheds. However, the selected small ponds were both 45 years old at the time of this study, and have reduced capacity because of being filled in with sediments. Additionally, trapping efficiency of these small ponds decreased over five observed storms, indicating that processes that suspended or resuspended sediments in these shallow ponds, such as wind and waves, affected their trapping efficiencies. While small ponds trapped sediments in small storms, they could be a source of sediment in larger or more closely spaced storm events. Channel slope was similar at all three watersheds, 0.40, 0.46, and 0.31 percent at Atchison County, Banner Creek, and Centralia Lake watersheds, respectively. Other factors, such as increased bank and stream erosion, differences in tile drainage, extent of grassland, or riparian buffers, could be the predominant factors affecting sediment yields from these basins. These results show that reference-like sediment yields may be observed in heavily agricultural watersheds through a combination of field-scale management activities and stream channel protection. When computing loads using published erosion rates obtained by single-point survey methodology, streambank contributions from the main stem of Banner Creek are three times more than the sediment load observed by this study at the sediment sampling site at Banner Creek, 2.6 times more than the sediment load observed by this study at the sediment sampling site at Clear Creek (upstream from Atchison County Lake), and are 22 percent of the load observed by this study at the sediment sampling site at Black Vermillion River above Centralia Lake. Comparisons of study sites to similarly sized urban and urbanizing watersheds in Johnson County, Kansas indicated that sediment yields from the Centralia Lake watershed were similar to those in construction-affected watersheds, while much smaller sediment yields in the Atchison County and Banner Creek watersheds were comparable to stable, heavily urbanized watersheds. Comparisons of study sites to larger watersheds upstream from Tuttle Creek Lake 
indicate the Black Vermillion River watershed continues to have high sediment yields despite 98 percent of sediment from the Centralia watershed (a headwater of the Black Vermillion River) being trapped in Centralia Lake. Estimated trapping efficiencies for the larger watershed lakes indicated that Banner Creek and Centralia Lakes trapped 98 percent of incoming sediment, whereas Atchison County Lake trapped 72 percent of incoming sediment during the 3 -year study period.

\section{Introduction}

In addition to natural variability in topography, soils, and geology, human activities affect the form, flow, and water quality of streams. Agricultural production has been the most widespread human-induced change to Kansas landscapes for the past 150 years (Broussard and Turner, 2009) and has been documented to accelerate surface erosion (Devlin and others, 2008), alter natural stream forms (Simon and Rinaldi, 2000), and contribute excess nutrients and pesticides to streams (Alexander and others, 2008; Gilliom and Hamilton, 2006). Among the most problematic issues created by these anthropogenic landscape changes is the increased transport of sediments, contributed from accelerated surface and stream channel erosion, to downstream impoundments used for flood control and drinking water. Large impoundments are the source of water for more than two-thirds of the population of the State of Kansas and sediment accumulation has decreased multipurpose pool capacity by more than 40 percent in several of these impoundments (deNoyelles and Jakubauskas, 2008).

Although factors controlling sediment erosion from agricultural areas have been extensively studied, deposition of eroded sediments and erosion of stream channels obscure relations between management practices and sediment transport in streams and rivers. Clear cutting of forested areas and poor agricultural practices can substantially increase erosion rates from agricultural areas, but sediment deposition in intervening fields and flood plains can cause downstream sediment yields to remain constant (Trimble, 1999). Similarly, resuspension of legacy sediments and stream channel erosion can obscure decreases in field-scale erosion associated with improved soil management (Trimble, 1999). Characterization of factors affecting sediment transport is complicated by substantial uncertainty in sediment transport estimates. Samples that represent high streamflow conditions are difficult to collect because of rapid water-level changes at sampling sites in small watersheds (Walling, 1977).

To characterize factors affecting sediment transport from small, agricultural watersheds in Kansas, the U.S. Geological Survey (USGS), in cooperation with the Kansas Water Office, collected streamflow and sediment data at sites upstream and downstream from three small impoundments (Atchison County, Banner Creek, and Centralia Lakes) in northeast Kansas from 2009 through 2011. Impoundments selected for study are within watersheds that vary with respect to current agricultural activities and management practices (fig. 1). In addition, the sites were located upstream and downstream from impoundments to compute sediment transport to, and the trapping efficiency of, each impoundment. This study is one component of a larger effort in cooperation with Academic, State, and Federal agencies to compile sediment budgets for the watersheds upstream from these impoundments. This report and study were supported in part through the Kansas State Water Plan Fund and the USGS Cooperative Water Program.

\section{Purpose and Scope}

The purpose of this report is to describe sediment transport to and from three small impoundments in northeast Kansas in relation to watershed characteristics and agricultural practices. This report describes data collected from March 2009 through September 2011 using continuously recording stage and water quality sensors at six sites, one upstream and downstream from each impoundment. Data collected from this study can be used to characterize important factors affecting sediment transport from small watersheds in northeastern Kansas. These data support Federal, State, and local efforts to improve water quality and identify processes affecting the transport of fluvial sediment.

\section{Description of Study Area}

Impoundments in this study vary in age and storage capacity. Atchison County Lake was constructed for recreation in 1935 and had an original storage capacity of 819 acre-feet (acre-ft) to the crest of the dam (elevation 1,055.5 feet (ft) National Geodetic Vertical Datum (NGVD) (Stene, 1946). Based on a 2010 survey by the Kansas Biological Survey (KBS), sediment accumulation has decreased the current storage capacity at the crest of the dam to approximately 185 acre-ft (Kansas Biological Survey, 2010a). Banner Creek Lake was completed in 1997 to serve as the water supply for the city of Holton, Kansas, and for recreational purposes. The approximate storage capacity of Banner Creek Lake is 7,400 acre-ft at a lake elevation of 1,078.1 ft NGVD as measured by a 2010 KBS bathymetric survey (Kansas Biological Survey, 2010b). Centralia Lake was completed in 1991 for water supply (the impoundment is not currently (2011) used for municipal water supply) and for recreational purposes. The approximate storage capacity of Centralia Lake is 4,000 acre$\mathrm{ft}$ at a lake elevation of $1,265.5 \mathrm{ft}$ NGVD as measured by a 2010 KBS survey (Kansas Biological Survey, 2010c).

Sediment-sampling sites (hereafter called "sampling sites") were located upstream from, and in or directly downstream from, Atchison County, Banner, and Centralia Lakes (table 1, fig. 2). Upstream sites were located at the furthest downstream location to best characterize streamflow and sediment transport to each impoundment. Because of multiple tributary inputs into streams and the necessity to install sampling 

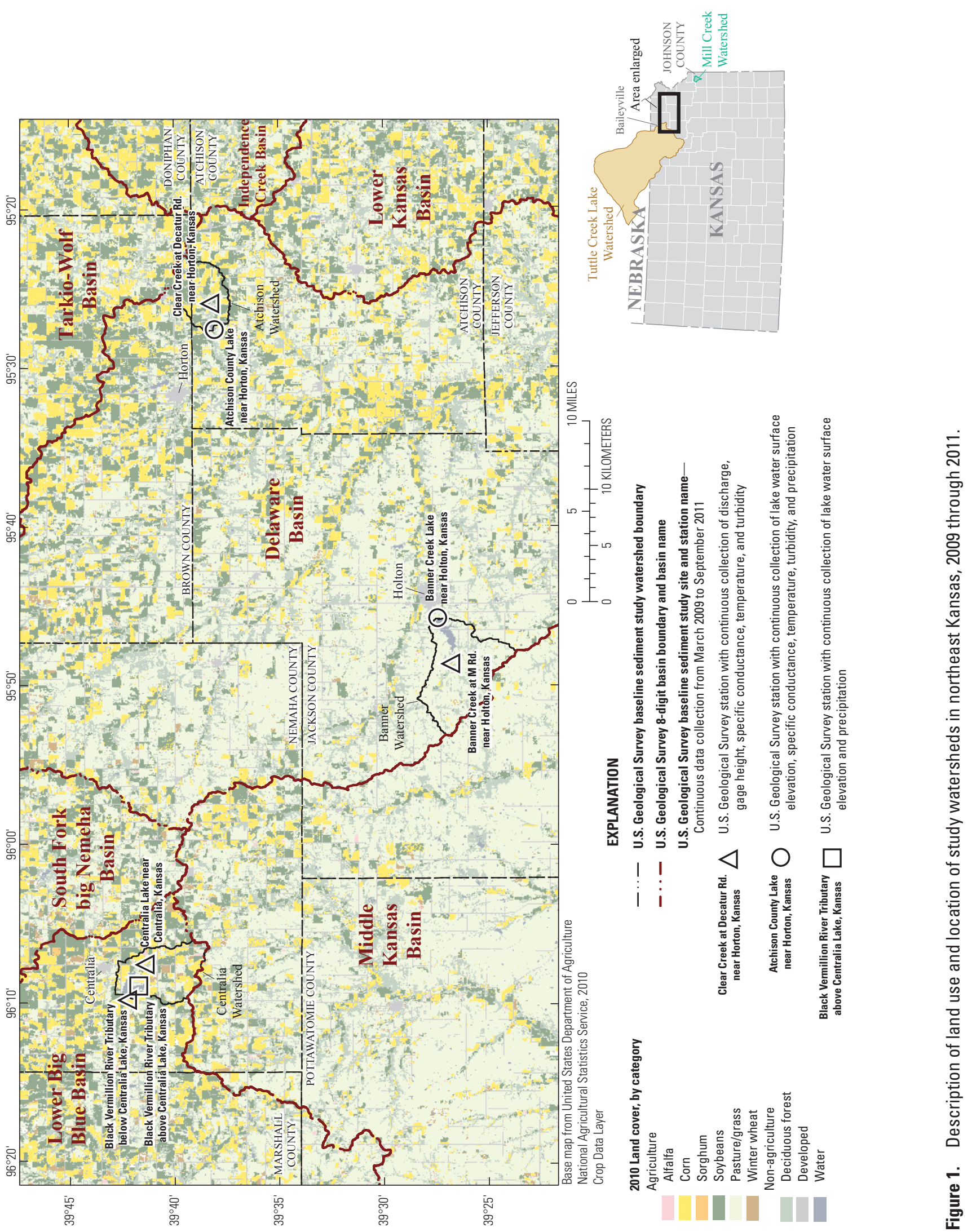
Table 1. Location and contributing drainage area of streamgages and sediment-sampling stations in Atchison, Jackson, and Nemaha counties in northeast Kansas during March 2009 through September 2011.

$\left[\mathrm{mi}^{2}\right.$, square miles]

\begin{tabular}{|c|c|c|c|c|}
\hline $\begin{array}{l}\text { U.S. Geological } \\
\text { Survey identifica- } \\
\text { tion number }\end{array}$ & Station name & $\begin{array}{c}\text { Contributing } \\
\text { drainage area } \\
\left(\mathrm{mi}^{2}\right)\end{array}$ & $\begin{array}{l}\text { Latitude } \\
\text { (degrees, min- } \\
\text { utes, seconds) }\end{array}$ & $\begin{array}{c}\text { Longitude } \\
\text { (degrees, min- } \\
\text { utes, seconds) }\end{array}$ \\
\hline 393817095260100 & Clear Creek at Decator Rd. near Horton, Kansas ${ }^{1,4}$ & 5.6 & $39^{\circ} 38^{\prime} 17^{\prime \prime}$ & $95^{\circ} 26^{\prime} 01^{\prime \prime}$ \\
\hline 393806095273700 & Atchison County Lake near Horton, Kansas ${ }^{1}$ & 9.1 & $39^{\circ} 38^{\prime} 06^{\prime \prime}$ & $95^{\circ} 27^{\prime} 37^{\prime \prime}$ \\
\hline 393806095274100 & Clear Creek below Atchison County Lake near Horton, Kansas ${ }^{2}$ & 9.1 & $39^{\circ} 38^{\prime} 06^{\prime \prime}$ & $95^{\circ} 27^{\prime} 37^{\prime \prime}$ \\
\hline 392652095484100 & Banner Creek at M Rd. near Holton, Kansas ${ }^{1,4}$ & 9.1 & $39^{\circ} 26^{\prime} 52^{\prime \prime}$ & $95^{\circ} 48^{\prime} 41^{\prime \prime}$ \\
\hline 392727095454500 & Banner Creek below Banner Creek Lake near Holton, Kansas ${ }^{2}$ & 19.1 & $39^{\circ} 27^{\prime} 27^{\prime \prime}$ & $95^{\circ} 45^{\prime} 49^{\prime \prime}$ \\
\hline 394126096073500 & Black Vermillion River tributary above Centralia Lake, Kansas ${ }^{1,4}$ & 4.4 & $39^{\circ} 41^{\prime} 26^{\prime \prime}$ & $96^{\circ} 07^{\prime} 35^{\prime \prime}$ \\
\hline 394146096085500 & Centralia Lake near Centralia, Kansas ${ }^{3}$ & 12.6 & $39^{\circ} 41^{\prime} 46^{\prime \prime}$ & $96^{\circ} 08^{\prime} 55^{\prime \prime}$ \\
\hline 394218096095000 & Black Vermillion River tributary below Centralia Lake, Kansas ${ }^{1}$ & 12.6 & $39^{\circ} 42^{\prime} 18^{\prime \prime}$ & $96^{\circ} 09^{\prime} 50^{\prime \prime}$ \\
\hline
\end{tabular}

${ }^{1}$ Sediment sampling station, water-quality monitor, and discharge gage.

${ }^{2}$ Separate site number used for lake outflow discharge, location same as elevation and water-quality monitor.

${ }^{3}$ Monitored only for continuous lake elevation.

${ }^{4}$ Upstream sampling site.

sites upstream from impoundments to avoid backwater conditions, upstream sites characterize only a part of streamflow and sediment transport to the impoundments. Upstream sampling sites characterized streamflow and sediment transport from 62 percent of the watershed upstream from Atchison County Lake (hereafter called 'Atchison watershed' or 'Atchison'), 48 percent of the watershed upstream from Banner Creek Lake (hereafter called 'Banner watershed' or 'Banner'), and 35 percent of the watershed upstream from Centralia Lake (hereafter called 'Centralia watershed' or 'Centralia') (table 1). Sampling sites located within and downstream from impoundments were selected to describe sediment trapping efficiency within studied impoundments.

Water elevation and turbidity also were collected at two small ponds $\left(<0.05 \mathrm{mi}^{2}\right)$ in the Atchison County Lake watershed to estimate sediment transport to and from small watershed ponds from April through August 2011. This information was then compared to the downstream sampling site to characterize the effect of the small ponds on total watershed sediment yield.

As part of an effort to compute sediment budgets upstream from each impoundment, Kansas State University (2009) characterized current land use and sediment management practices using surveys of selected local property owners (table 2). Assessed land use in the Atchison and Centralia watersheds consisted predominantly of cultivated crops (a minimum of 52 and 53 percent, respectively), and grassland (4.1 and 12 percent, respectively; table 2). The Banner watershed had minimal cultivated crops (2.9 percent), and primarily consisted of grassland (63 percent, table 2).
Among watersheds with substantial cropland (Atchison and Centralia), management practices were implemented on most of the cultivated land. Soybeans and corn were the primary crops grown during the survey period and most of these were farmed using reduced or no-till farming techniques (87 percent of Atchison and 70 percent of Centralia; table 2). Terraces also were implemented on most of the fields in these watersheds (86 percent of Atchison and 96 percent of Centralia; table 2). Tile drains were more extensively used for drainage at Atchison (41 percent) than Centralia (22 percent).

The USGS National Land Cover Database (2001) was used to characterize recent historical land use types among watersheds upstream from streamgages and sedimentsampling stations (table 3; fig. 1). Land uses were aggregated from 14 into a subset of 7 classes (open water, urban/barren land, forest, grassland/shrubland, pasture/hay, cultivated crops, and wetlands/streams; table 3). Land use was similar to data collected by current (2009) on-site surveys. Watersheds upstream from Atchison County and Centralia Lakes consisted predominantly of cultivated crops (53.5 and 56.2 percent, respectively), and secondarily pasture and grassland (34.4 and 32.3 percent, respectively; table 3 ). The watershed upstream from Banner Creek Lake had minimal cultivated crops (3.9 percent) and primarily consisted of pasture (69.4 percent; table 3).

The Atchison, Banner, and Centralia watersheds are located in the Dissected Till Plains section of the central lowland province of the interior plains. Soils in each watershed were formed from parent material consisting of limestone and shale, glacial till, loess, and alluvium. Upstream from each impoundment, soils generally are deep, moderately 

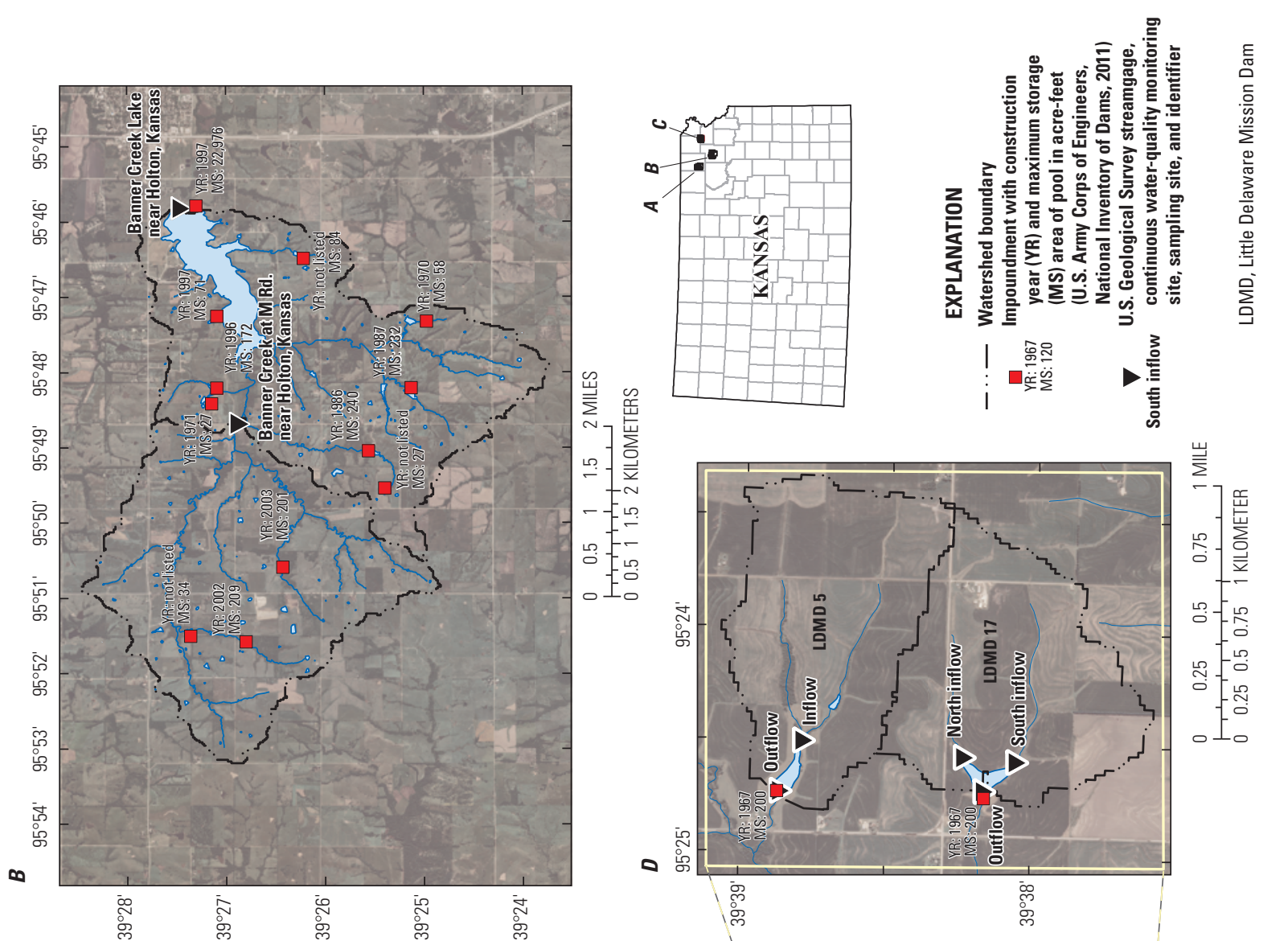

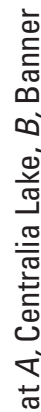
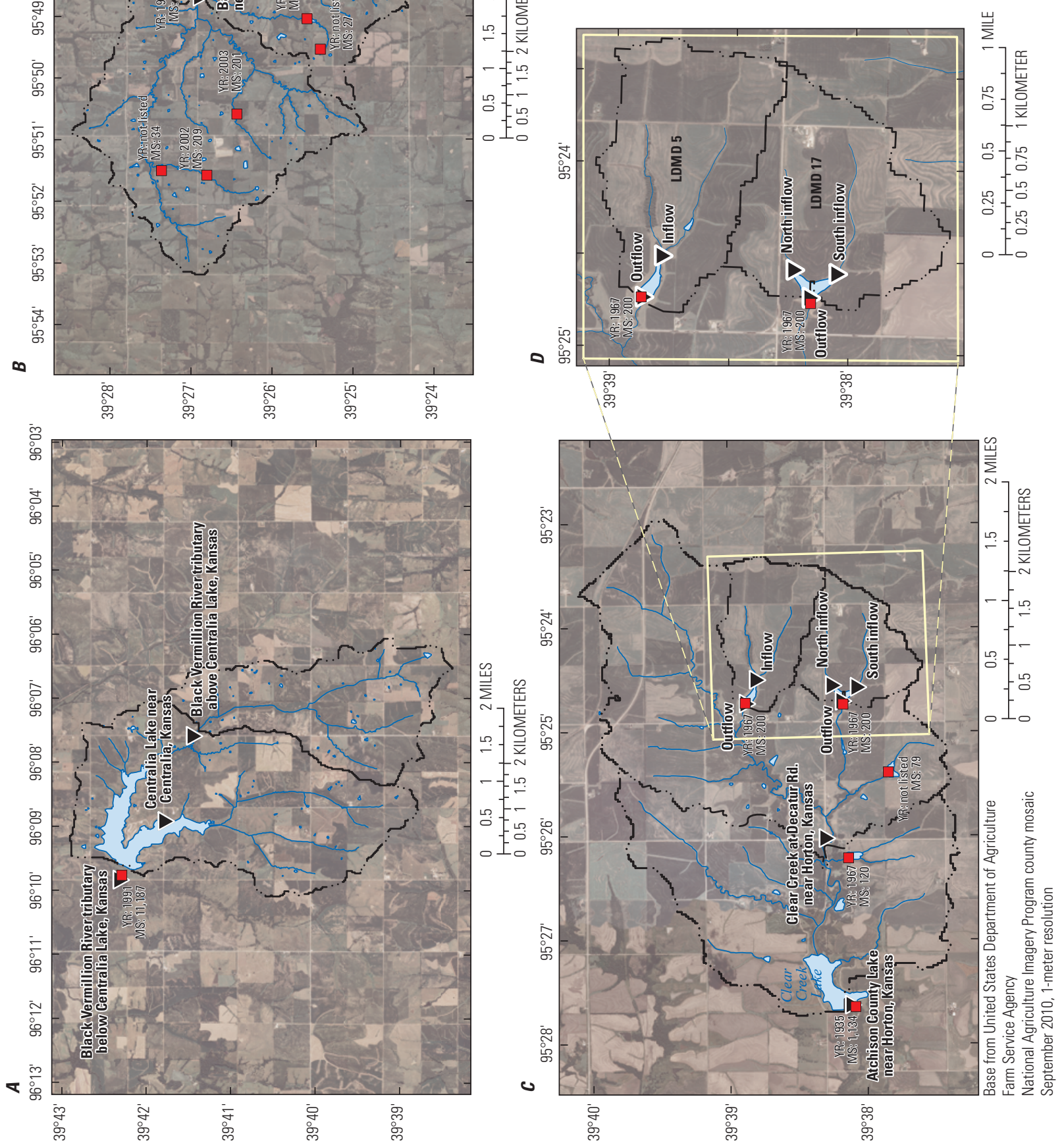
Table 2. Land use and sediment management practices upstream from sediment-sampling stations in northeast Kansas, obtained from on-site surveys, 2009.

[Data from Kansas State University, 2009; $\mathrm{mi}^{2}$, square miles]

\begin{tabular}{|c|c|c|c|c|c|c|c|c|}
\hline \multirow[b]{2}{*}{ Station name } & \multirow{2}{*}{$\begin{array}{l}\text { Contributing } \\
\text { drainage } \\
\text { area } \\
\left(\mathrm{mi}^{2}\right)\end{array}$} & \multicolumn{4}{|c|}{ Percentage land use } & \multicolumn{3}{|c|}{ Percentage of cropland } \\
\hline & & $\begin{array}{l}\text { Crop- } \\
\text { land }\end{array}$ & $\begin{array}{l}\text { Grass- } \\
\text { land }\end{array}$ & Other & $\begin{array}{l}\text { Not } \\
\text { assessed }\end{array}$ & $\begin{array}{c}\text { Under } \\
\text { reduced or } \\
\text { no tillage }\end{array}$ & Terraced & $\begin{array}{c}\text { Tile } \\
\text { drained }\end{array}$ \\
\hline Clear Creek at Decator Rd. near Holton, Kansas & 5.6 & 63 & 2.9 & 3.3 & 31 & 91 & 82 & 44 \\
\hline Atchison County Lake near Horton, Kansas & 9.1 & 52 & 4.1 & 7.3 & 37 & 87 & 86 & 41 \\
\hline Banner Creek at M Rd. near Holton, Kansas & 9.1 & 3.3 & 66 & 9.2 & 22 & 22 & 3 & 6 \\
\hline $\begin{array}{l}\text { Black Vermillion River tributary above } \\
\text { Centralia Lake, Kansas }\end{array}$ & 4.4 & 58 & 15 & 4.1 & 23 & 73 & 92 & 18 \\
\hline $\begin{array}{l}\text { Black Vermillion River tributary below } \\
\text { Centralia Lake, Kansas }\end{array}$ & 12.6 & 53 & 12 & 16 & 20 & 70 & 96 & 22 \\
\hline
\end{tabular}

well-drained, and of moderately slow permeability (Campbell and others, 1979; Sallee and Watts, 1984; Abel, 2005). Erosivity $(\mathrm{K})$ factors of the predominant soil types upstream from each impoundment are described as moderately ( $\mathrm{K}$ factor from 0.2 to 0.4 ) to highly erosive (greater than 0.4) (Campbell and others, 1979; Sallee and Watts, 1984; Abel, 2005).

Surface topography in the Atchison County and Centralia Lake watersheds are affected predominantly by glacial till (Kansas Data Access and Support Center, 2011), whereas approximately 28 percent of the topography upstream from Banner watershed is affected by limestone and shale formations (the rest is primarily affected by glacial till). Given the low permeability of surficial soils in all watersheds, most of the stormflow likely originates from overland, shallow subsurface, or tile-drained flow. Streams generally flow through glacial till; streambeds at sampling sites are primarily silt/clay, sand, cobble, and rock.

Mean annual temperature and precipitation were similar among meteorological stations near monitored impoundments despite varied lengths and missing records. Mean annual temperature at Horton, Kansas (near Atchison watershed from 1893-2008, excluding 1903, 1931, and 2006, National Weather Service (NWS) site number 00143810) was 53.6 degrees Fahrenheit $\left({ }^{\circ} \mathrm{F}\right)$ and mean annual precipitation from 1893-2008 (excluding 2006) was 35.6 inches (in.). Mean annual temperature at Holton, Kansas (near Banner watershed, NWS site number 00143759) from 1954-2008 (excluding 1955, 1968, 1979, 1984, 1987, 1998-2000, and 2004) was $53.0^{\circ} \mathrm{F}$ and mean annual precipitation from 1931-2008 (excluding 1979, 1984-87, and 1990-2000) was 35.2 in.

Table 3. Recent historical land use upstream from streamgages and sediment-sampling stations in northeast Kansas during March 2009 through September 2011.

[Data from the U.S. Geological Survey National Landcover Database, Homer and others, 2004; $\mathrm{mi}^{2}$, square miles]

\begin{tabular}{|c|c|c|c|c|c|c|c|c|}
\hline \multirow[b]{2}{*}{ Station name } & \multirow{2}{*}{$\begin{array}{l}\text { Contribut- } \\
\text { ing drain- } \\
\text { age area } \\
\left(\mathrm{mi}^{2}\right)\end{array}$} & \multicolumn{7}{|c|}{ Percentage land use } \\
\hline & & $\begin{array}{l}\text { Open } \\
\text { water }\end{array}$ & $\begin{array}{c}\text { Urban/ } \\
\text { barren land }\end{array}$ & Forest & $\begin{array}{l}\text { Grassland/ } \\
\text { shrubland }\end{array}$ & $\begin{array}{l}\text { Pasture/ } \\
\text { hay }\end{array}$ & $\begin{array}{l}\text { Cultivated } \\
\text { crops }\end{array}$ & $\begin{array}{l}\text { Wetlands/ } \\
\text { streams }\end{array}$ \\
\hline Clear Creek at Decator Rd. near Holton, Kansas & 5.6 & 0.7 & 5.5 & 4.1 & 0.9 & 29.0 & 59.7 & 0.1 \\
\hline Atchison County Lake near Horton, Kansas & 9.1 & 1.7 & 5.6 & 4.6 & 2.6 & 31.8 & 53.5 & 0.2 \\
\hline Banner Creek at M Rd. near Holton, Kansas & 9.1 & 0.2 & 5.1 & 11.6 & 11.7 & 67.0 & 4.3 & 0.1 \\
\hline Banner Creek Lake near Holton, Kansas & 19.1 & 4.8 & 4.1 & 10.0 & 7.8 & 69.4 & 3.9 & 0.0 \\
\hline $\begin{array}{l}\text { Black Vermillion River tributary above } \\
\text { Centralia Lake, Kansas }\end{array}$ & 4.4 & 0.3 & 3.7 & 1.4 & 19.7 & 6.0 & 68.9 & 0.0 \\
\hline $\begin{array}{l}\text { Black Vermillion River tributary below } \\
\text { Centralia Lake, Kansas }\end{array}$ & 12.6 & 5.5 & 4.1 & 1.9 & 27.3 & 5.0 & 56.2 & 0.0 \\
\hline
\end{tabular}


Mean annual temperature at Centralia, Kansas (near Centralia watershed, NWS site number 00141408) from 1933-2006 was $53.6^{\circ} \mathrm{F}$ and mean annual precipitation from 1931-2006 (excluding 1979, 1984-87, and 1990-2000) was 33.8 in. (National Oceanic and Atmospheric Administration, 2012).

Stream-channel elevation was estimated along the length of the longest stream-reach contributing to each impoundment to characterize potential differences in sediment transport capacity (fig. 3; Horizon Systems, 2010). Stream elevation was estimated by dividing the longest stream channel contributing to each impoundment into equidistant, 30 -meter (m) segments and obtaining the elevation for each point from the USGS 30-m digital elevation model (DEM) for the study area (Horizon Systems, 2010). Small-scale elevation changes among elevation points are dependent on the underlying accuracy of small-scale elevation changes in the DEM. DEMs were estimated before the impoundment of Banner Creek and Centralia Lakes and thus elevation continues to decrease within these impoundments (fig. 3). Banner Creek was the longest stream and had approximately twice the elevation loss compared with the other streams (fig. 3). Mean channel slope (in percent) was calculated by subtracting the stream elevation (in feet) at a location 10 percent of the stream channel length upstream from the downstream sampling site location from

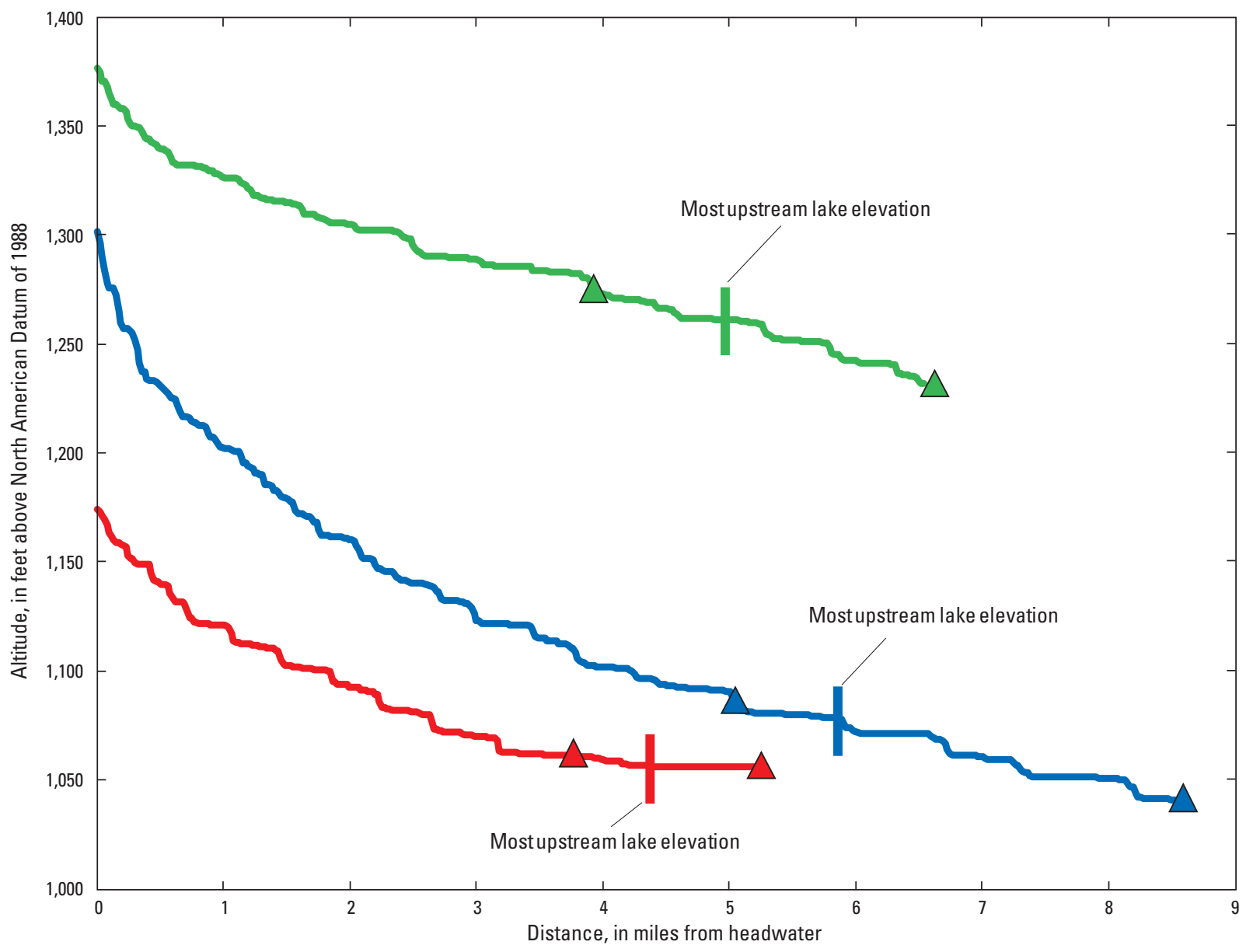

EXPLANATION

Longitudinal profile of stream-Triangle indicates elevation and location of upstream or downstream sampling site. Most upstream lake elevation from the National Agriculture Imagery Program (U.S. Department of Agriculture, 2008)

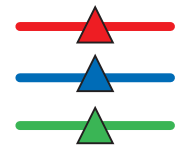

Clear Creek (Atchison County Lake)

Banner Creek (Banner Creek Lake)

Black Vermillion River (Centralia Lake)

Figure 3. Longitudinal profiles of streams upstream from study impoundments in northeast Kansas. 
the stream elevation at a point 85 percent of the stream length upstream from the downstream sampling site location, and dividing the elevation difference by the stream length (in feet) between these two points. Banner Creek had the steepest channel (0.46-percent slope), Clear Creek (upstream from Atchison County Lake) had a 0.40 -percent slope, and the Black Vermillion River tributary upstream from Centralia Lake had a 0.31-percent slope (fig. 3).

Small impoundments (hereafter referred to as 'ponds') upstream from monitored impoundments were characterized by analysis of surface-water from satellite data from the National Hydrography Database (NHDPlus; Horizon Systems, 2010) and by analysis of data from the National Inventory of Dams (NID; U.S. Army Corps of Engineers, 2011). NHDPlus data provide a more complete picture of the number, spatial extent, and total surface area of dams within these watersheds because NID data do not include all dams (especially smaller dams); however, NID data indicate when dams were completed and estimate upstream drainage area and impoundment volume (fig. 2). Smaller ponds identified in the NHDPlus do not have any information other than that there is surface water, and therefore these ponds may not be permanent on an annual basis. Because of this, the NHDPlus could underrepresent the total number of ponds because of some ponds being dry at the time of the survey. The Banner watershed had the largest number of smaller, non-NID listed ponds (166) and largest area (0.15 square miles $\left(\mathrm{mi}^{2}\right)$ of surface water (aside from Banner Creek Lake; fig. 2) (NHDPlus, Horizon Systems, 2010). The watershed upstream from Banner Creek Lake also had the largest number of NID dams (11) and six were constructed in the past 25 years (three NID dams did not have information on the date of construction; fig. 2) (NID, U.S. Army Corps of Engineers, 2011). The seven dams with information on upstream watershed area indicated that they affected $2.5 \mathrm{mi}^{2}$ of the Banner Creek Lake watershed drainage area (draining approximately 13 percent of the entire Banner Creek Lake watershed). The Atchison watershed had 18 separate surfacewater bodies (other than Atchison County Lake) with a surface-water area totaling $0.06 \mathrm{mi}^{2}$ (NHDPlus, Horizon Systems, 2010). Of the four NID dams, three were built in 1967 (the fourth dam did not have construction data). The four NID listed ponds upstream from Atchison County Lake affected $2.4 \mathrm{mi}^{2}$ of the Atchison watershed drainage area (approximately 26 percent of the entire Atchison watershed). The Centralia Lake watershed had 87 separate surface-water bodies (none by NID), with a surface-water area totaling $0.04 \mathrm{mi}^{2}$ (NHDPlus, Horizon Systems, 2010).

\section{Previous Studies}

Few studies have been completed on sediment transport from agricultural areas in northeastern Kansas. Collins (1965) calculated average sediment yields as ranging from 2,000 to 5,000 tons per square mile per year (tons $/ \mathrm{mi}^{2} / \mathrm{yr}$ ) in northeast Kansas, and characterized erosion hazards as primarily relating to sheet and gully erosion from croplands. The Kansas Department of Health and Environment (KDHE) collects water-quality data in Atchison County, Banner Creek, and Centralia Lakes to establish total maximum daily loads (TMDLs). KDHE has established TMDLs for eutrophication, nutrients, and $\mathrm{pH}$ for Centralia Lake, but currently (2011) has not established TMDLs for Atchison County or Banner Creek Lakes. Banner Creek previously had a TMDL for eutrophication that was removed after observed chlorophyll levels decreased after best management practices were implemented from 1997 through 2007 (U.S. Environmental Protection Agency, 2009).

Many studies have been completed that provide precedent for approaches used in this study. Christensen and others (2001), Putnam and Pope (2003), Rasmussen and others (2005, 2009), Lee and others (2008a, b), and Lee and Ziegler (2010a, b) have indicated that relations between continuous turbidity and discreet samples provide accurate computations of suspended-sediment concentrations, and combined with continuous streamflow data provide accurate estimations of loads and yields in Kansas streams.

\section{Methods}

\section{Data Collection and Analysis}

Sampling sites were installed upstream from and in, or directly downstream from, study impoundments during March 2009. YSI (YSI Inc.) water quality monitors equipped with specific conductance, water temperature, and model 6136 turbidity sensors were installed at each site and were housed in polyvinyl chloride (PVC) pipes with holes drilled to facilitate flow through the installation. Monitors were installed at the stream or impoundment edge, approximately $0-2 \mathrm{ft}$ above the stream or lakebed. Site locations upstream from study impoundments were selected to represent sediment transport from the largest sub-watershed contributing to each impoundment while accounting for site suitability and attempting to avoid backwater conditions. Data were collected every 15 minutes from March 2009 to September 2011; these data are available on the USGS Kansas Water Science Center Web page (http://nrtwq.usgs.gov/ks/). Monitor maintenance and data reporting generally followed procedures described in Wagner and others (2006) with the exception of increased length between calibration checks (approximately 2-3 months), monitor cleanings were performed approximately every 6 weeks, or as needed. Length between calibration checks was extended beyond the recommended monthly frequency because of the absence of $\mathrm{pH}$ and dissolved oxygen sensors, which are prone to calibration drift. Turbidity records generally were rated good (error of 5-10 percent) 
and occasionally fair (error of 10-15 percent) on the basis of guidelines developed by Wagner and others (2006).

USGS-approved stage sensors were installed to measure water level (gage height in streams and elevation above mean sea level (M.S.L.) in lakes) using methods described in Sauer and Turnipseed (2010). Streamflow was measured and calculated using methods described in Rantz (1982), Turnipseed and Sauer (2010), Kennedy (1983), and Oberg and others (2005). Rating curves comparing gage height and streamflow were developed using streamflow measurements and the slope-conveyance method (Kennedy, 1984).

Suspended-sediment samples were collected using methods described in Gray and others (2008) and Nolan and others (2005). Samples were analyzed for suspended-sediment concentration (SSC), percentage of sediments less than 63 micrometers $(\mu \mathrm{m})$ (sand-fine break), and loss of material on ignition (analogous to amount of organic matter). Selected samples also were analyzed for grain-size distribution (percent of sediment less than 2, 4, 8, 16, and $31 \mu \mathrm{m}$ in diameter). Samples were analyzed at the USGS Sediment Laboratory in Iowa City, Iowa, using methods described by Guy (1969).

\section{Quality Assurance}

Turbidity values were measured across the width of the stream or adjacent to the impoundment monitoring site during the collection of suspended-sediment samples. Mean values of cross-sectional measurements of turbidity are compared with fixed in-place turbidity sensors and analyzed by linear regression (Rasmussen and others, 2009) to confirm the ability of the in-place sensor to accurately represent the turbidity through the stream cross-section or lake discharge. Five samples were removed prior to making these comparisons because of errors identified in turbidity or suspended sediment values. At sites with more than 100 Formazin Nephelometric Units (FNU) range in values, in-place turbidity sensors accurately represented mean cross-sectional values. In-place sensors represented between 94 and 96 percent of the variability, and had slopes between .85 and 1 at Clear Creek at Decator Rd. (upstream from Atchison County Lake), Banner Creek at M Rd., Black Vermillion River above Centralia Lake, and Atchison County Lake (fig. 4). Variability at higher flows was likely caused by extreme temporal variability in turbidity during high flow conditions. The comparisons described 76 to 96 percent of the variance. At Banner Creek Lake and Black Vermillion River below Centralia Lake, relatively small ranges in turbidity values increased variability among in-stream and cross-sectional median values. Measurements that plotted outside of a 1:1 fit likely were caused by localized differences in turbidity or instrument error. Specifically, Clear Creek at Decatur Rd. (upstream from Atchison County Lake), Atchison County Lake, and Banner Creek at M Rd. compared well, with slopes between 0.91 and 1.00. Banner Creek Lake had the smallest range of turbidity values, and consequently had a larger variance in the comparison between sensors (slope of
1.17), which also was a result of the range of measured values that are at the low end of the sensor detection limit. At this low range, the difference can be explained in part because of calibration differences between instruments, and minor disturbances to the surrounding lake bed or monitor housing that could easily stir up enough material to cause a few turbidity units difference in recorded values. Turbidity values measured at Black Vermillion River above Centralia Lake indicated good agreement except for three samples in the upper range causing slope to decrease to 0.85 . In each of the three cases the in-place monitor was higher than the field sonde used to sample, and could have been caused by sediment filling in the sonde housing (which was a common occurrence after storms at that site). Because consistent bias was not observed, with the exception of noted outliers, values from continuous-water quality monitors were considered representative of stream or impoundment-outflow water quality conditions.

One set of double-blind samples (a total of 10 individual samples) were prepared and sent in to the Iowa sediment lab to assess the quality of the lab. Double-blind sample results were less than 6 percent error for 7 out of 10 of the samples. Samples prepared at 10 milligrams per liter $(\mathrm{mg} / \mathrm{L})$ were returned at $15 \mathrm{mg} / \mathrm{L}$ (all fines) and $17 \mathrm{mg} / \mathrm{L}$ (50 percent fines, 50 percent sand). One high SSC sample, $5,000 \mathrm{mg} / \mathrm{L}$ (50 percent fines, 50 percent sand) came back with a result of $2,507 \mathrm{mg} / \mathrm{L}$; however, the lab sample sheet indicates a value transcription error. No other separate quality assurance samples were taken because of the large number of samples being taken over the study period, and the lack of variability typically seen in studies of this type (Lee and others, 2008a, 2008b; Lee and Ziegler, 2010a, 2010b; Juracek, 2011). Numerous redundant samples were collected at similar turbidity values and flows (figs. 5 and 6).

\section{Regression Models}

Ordinary-least squares regression was used to compute continuous, 15-minute estimates of SSC from in-stream turbidity measurements using methods described in Rasmussen and others (2009). SSC, turbidity, and discharge relations were evaluated at each site using single (SLR) and multiple (MLR) linear regressions for normal and logtransformed data (table 4; fig. 5). Samples collected during low (less than 0.5 cubic feet per second $\left(\mathrm{ft}^{3} / \mathrm{s}\right)$ ) streamflow, or when turbidity was less than 2 NTU, were not used because of inherent error associated with those low readings (resolution is $0.1 \mathrm{NTU}$ ), and accuracy is \pm 2 percent of reading or $0.3 \mathrm{NTU}$, whichever is greater; (YSI Incorporated, 2010), including 5 samples from Clear Creek (upstream from Atchison Lake), 4 from Banner Creek, 2 from Banner Lake, and 3 each from Black Vermillion above and below Centralia Lake. Statistics were evaluated for each of the resulting models from each site using guidelines described by Rasmussen and others (2009) and final models were selected based on the most statistically accurate model. A single outlying sample was removed at 


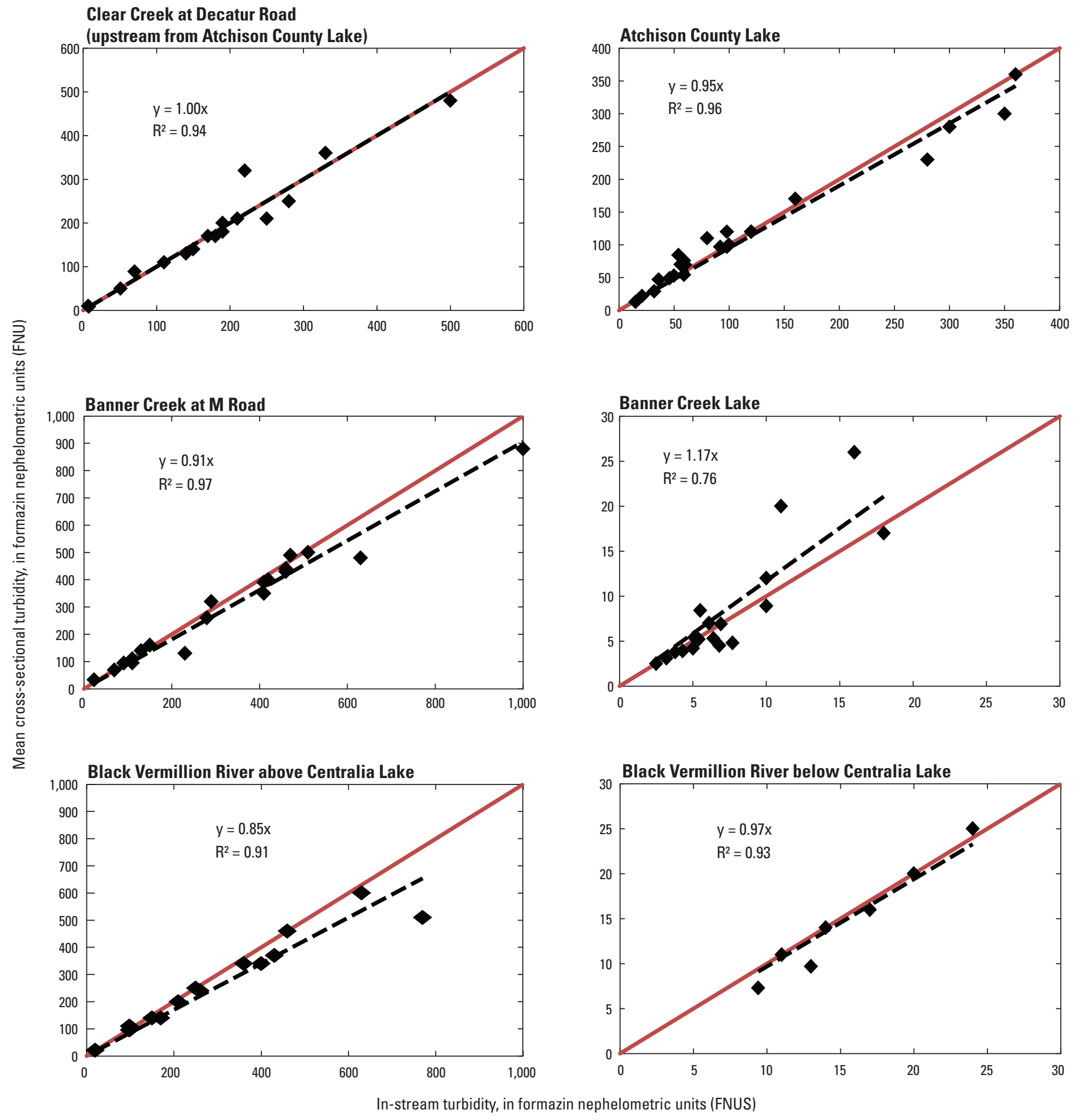

EXPLANATION

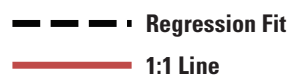

Figure 4. Relation between cross-sectional mean (or independent reading in the case of the lakes) and in-place turbidity readings at study sites during March 2009 through September 2011. 

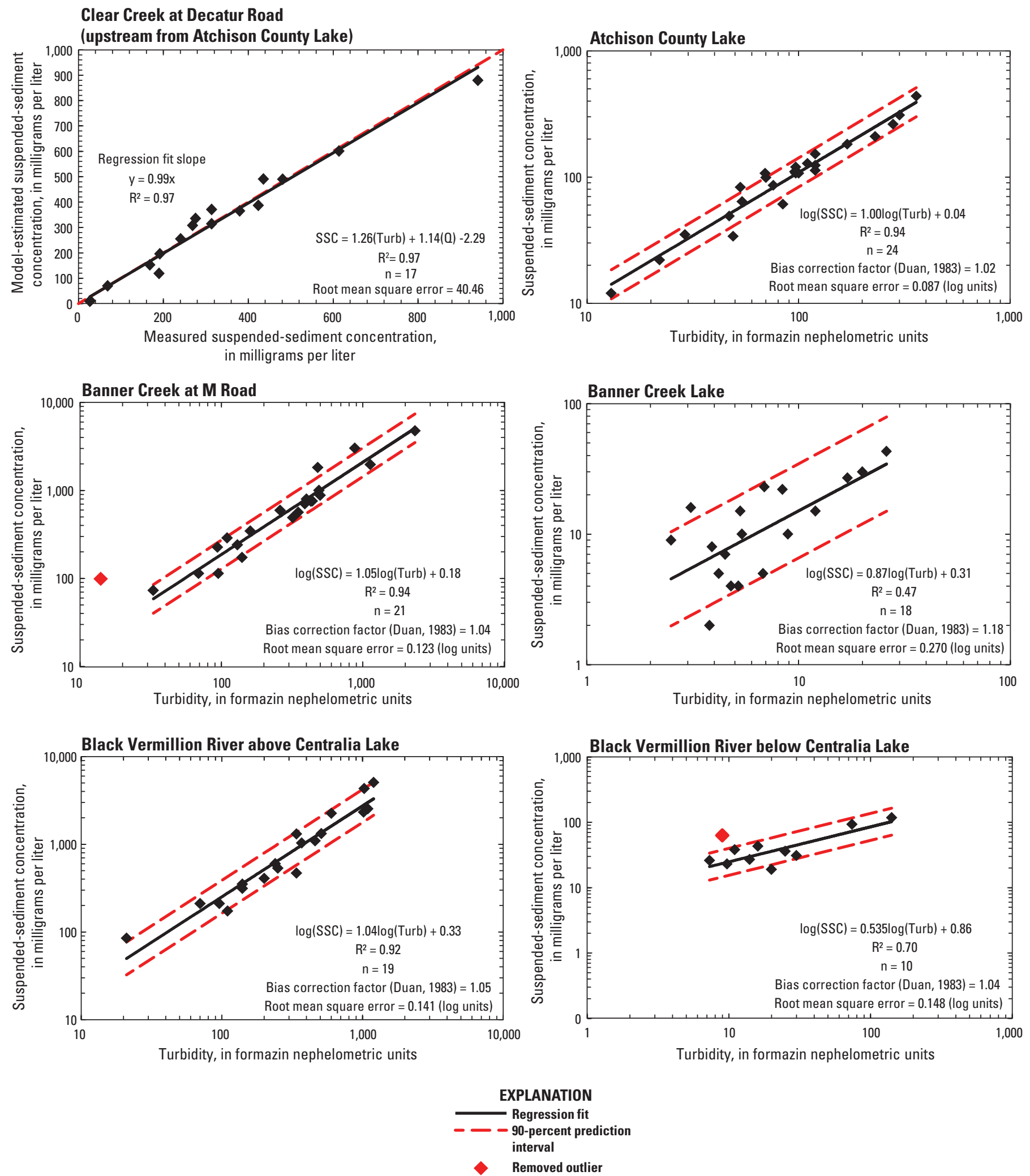

Figure 5. Comparison of measured and model-estimated suspended-sediment concentrations for the multiple linear regression at Clear Creek at Decatur Rd. (upstream from Atchison County Lake), and single linear regression relations between turbidity and suspended-sediment concentrations with removed outliers in red for other sediment sampling sites during March 2009 through September 2011. 
Clear Creek at Decatur Road (upstream from Atchison County Lake)

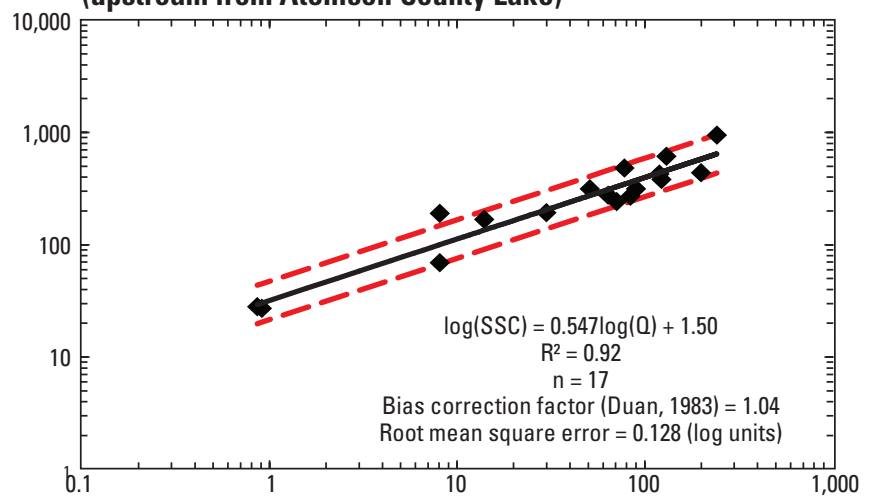

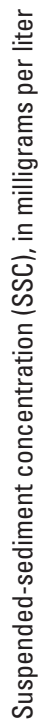
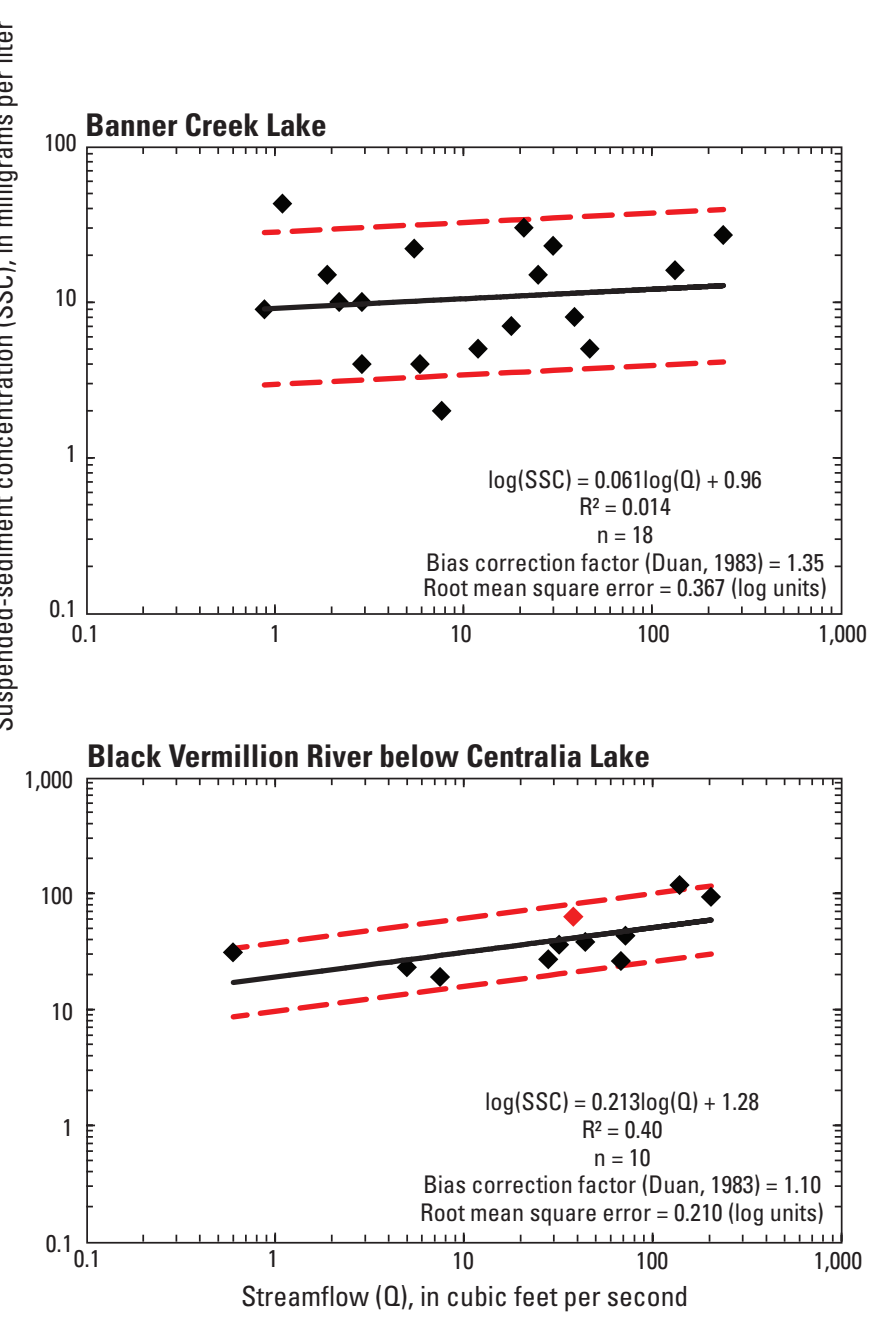

Banner Creek at M Road

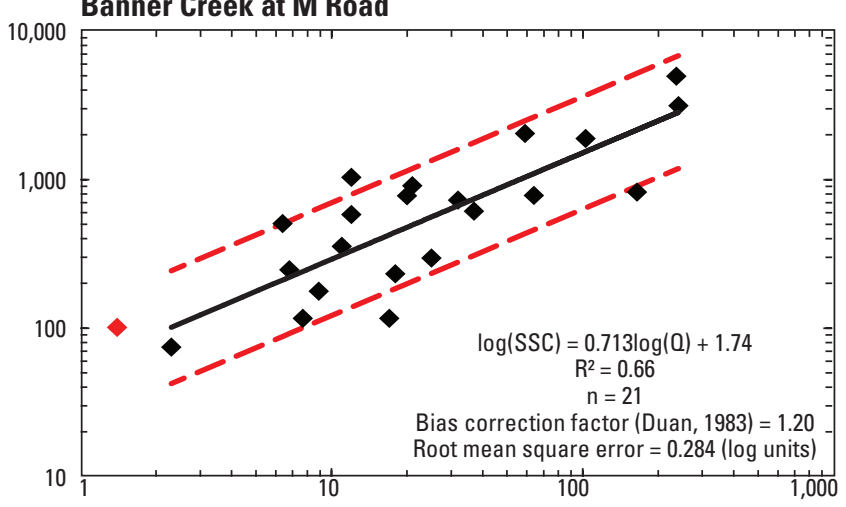

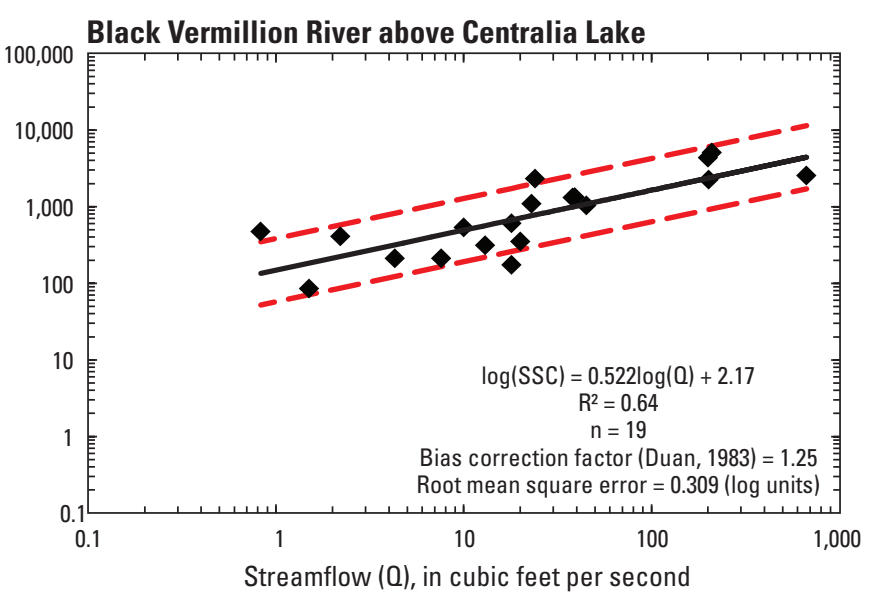

EXPLANATION

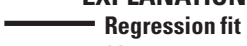

-- - 90-percent prediction

interval

$\checkmark$ Removed outlier

Figure 6. Relations between discharge and suspended-sediment concentration at study sites with removed outliers in red (if removed from turbidity models, also removed from streamflow models) during March 2009 through September 2011. 


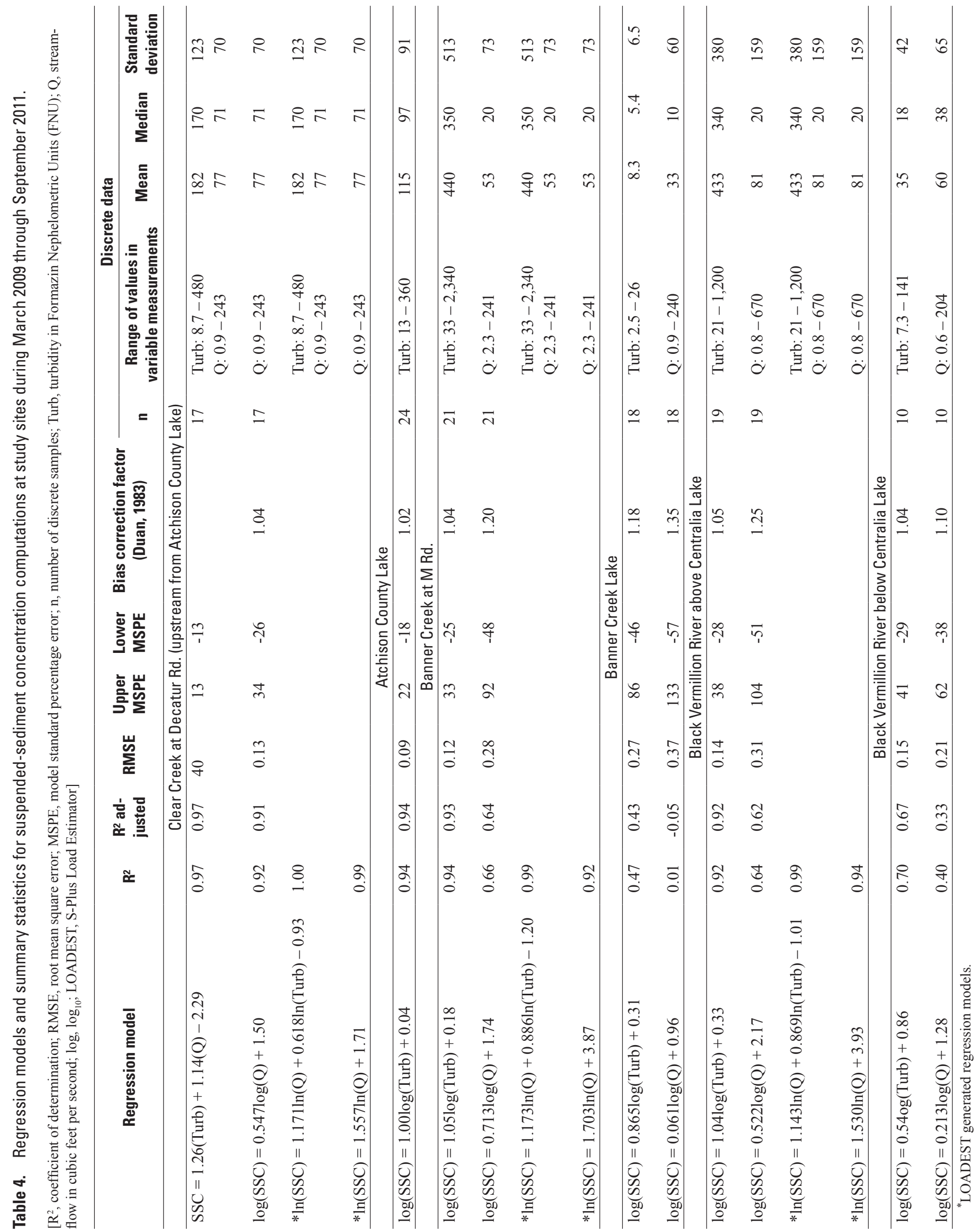


Banner Creek at M Rd. and Black Vermillion River below Centralia Lake because of their large effect on overall slope, indicating an error in collection or analysis, although the specific issue was not readily apparent. After these outliers were removed from the first regression model assessed, no further samples were removed regardless of where on the regression line they plotted.

Turbidity-SSC regressions were the primary method for computing the continuous SSC record; however, streamflowbased regressions also were developed for periods of variable flow in which turbidity sensors were not working. These methods are discussed in detail in the section titled "Estimating Sediment Transport During Periods of Missing Turbidity Data." Regression relations using log-transformed data were retransformed back to a linear scale, which can cause bias when adding load estimates with time. To correct this, a biascorrection factor (Duan's smearing estimator; Duan, 1983) was calculated to correct for potential bias (Helsel and Hirsch, 2002). Uncertainty of regression estimates were determined by calculating 90-percent prediction intervals (Helsel and Hirsch, 2002) (fig. 5). The USGS LOADEST (Runkel and others, 2004) program was also used in order to evaluate the uncertainty of suspended-sediment load estimates, and is discussed in detail in the section titled "Computation of Sediment Concentrations, Trapping Efficiencies, Loads, and Yields." Continuous suspended-sediment concentration and load computations, uncertainty, and duration curves are available on the World Wide Web at URL http://nrtqw.usgs.gov/ks/.

Similarities between regression equations at Atchison County Lake, Banner Creek at M Rd., and Black Vermillion River above Centralia Lake indicate similarities in sediment grain-size and color. Slopes in regression equations at Banner Creek Lake and Black Vermillion River below Centralia Lake were less than 1:1 (0.87 and 0.54 , respectively) because of very low ranges of observed and measured turbidity and corresponding SSC values (table 4). Over the entire period of the study, turbidity ranged from 2.5 to 26 NTU at Banner Creek Lake, and 7.3 to 141 NTU at Black Vermillion River below Centralia Lake (table 4). Long residence times were expected at Banner Creek Lake and Centralia Lake (Centralia Lake outflow being gaged at the Black Vermillion River below Centralia Lake), allowing sediments carried in by the inflow streams to settle out in the impoundment before reaching the outflow structure (residence time is discussed in more detail in the section titled "Trapping Efficiencies"), which explains the limited range of recorded turbidity values. At these low turbidity ranges, sensor accuracy is less because the sensor values are easily affected by random suspended particles (such as small animals or algae) in the sensor's detection zone. This has resulted in the poor coefficient of determination $\left(\mathrm{R}^{2}\right)$ values in the regression models for both Banner Creek Lake and Black Vermillion River below Centralia Lake. In the case of Clear Creek at Decator Rd. (upstream from Atchison County Lake), a MLR was determined to be the most statistically valid model based on model standard percentage error (MSPE) as specified in Rasmussen and others (2009). MSPE is the root-mean-squared-error (RMSE, a measure of the variance between regression-computed and observed values) expressed as a percent, and represents the uncertainty associated with the regression-computed values (Rasmussen and others, 2009). The MLR model of SSC $\approx$ Turb, Q, indicated a MSPE of +13 to -13 percent, whereas the SLR model of $\log (\mathrm{SSC}) \approx \log$ (Turb) (like that used in all other models) indicated a MSPE of +23.09 to -18.76 percent. Sediment loads computed using MLR and SLR models were similar, with the SLR model computing about 12 percent less sediment load during the study period than the MLR model. Because the MSPE of the MLR was the lowest, sediment loads from that model were used in the final computations.

\section{Computation of Sediment Concentrations, Trapping Efficiencies, Loads, and Yields}

The regression models were used to calculate continuous (15-minute) estimates of SSC at each sampling site. Timeseries (15-minute) discharge values (in $\mathrm{ft}^{3} / \mathrm{s}$ ) were multiplied by 15 -minute computations of SSC and by a unit-conversion factor $[\times 1 / 1,000 \mathrm{mg} / \mathrm{g}($ milligram per gram), $\times 1 / 453.6 \mathrm{~g} / \mathrm{lb}$ (gram per pound), and $\times 28.32 \mathrm{~L} / \mathrm{ft}^{3}$ (liter per cubic foot)] to compute time-series suspended-sediment discharge in pounds per second (lbs/s). Fifteen-minute sediment discharge computations were summed and multiplied by a unit conversion factor [ $\times 900$ seconds $\times 1$ ton/2,000 lbs (pounds)] to compute sediment loads (in tons) for periods of interest.

Sediment and streamflow yields were computed by dividing the total load (in tons) or total flow (in acre-ft) by drainage area $\left(\right.$ in $^{2}{ }^{2}$ ). Streamflow yield was converted to depth of runoff (in inches) by a unit conversion factor $[\times 1$ acre-ft/ $\mathrm{mi}^{2} \times 43,560 \mathrm{ft}^{3} /$ acre $\times 1$ mile $/ 5,280 \mathrm{ft}^{2} \times 12$ inches $\left./ 1 \mathrm{ft}\right]$, and represents the volume of water covering the entire watershed as depth. The trapping efficiency of each impoundment was calculated by subtracting the total sediment load transported from the impoundment from the estimated load transported into the impoundment and dividing by the estimated total sediment load transported into the impoundment, and then multiplying by 100 .

Suspended-sediment loads and yields were approximated for the ungaged drainage area upstream from each impoundment using data from existing monitoring sites. Sediment yields from upstream monitoring sites were multiplied by the entire impoundment drainage area to estimate total sediment transport to the impoundment for each time period of interest. These methods do not take into account heterogeneity in natural features, precipitation, and land practices across upstream watersheds, but provide an approximation of total streamflow and sediment transport to each impoundment.

To better assess the uncertainty of computed sediment loads, sample data also were run through S-plus Load Estimator (LOADEST) software (Runkel and others, 2004). LOADEST primarily is designed for large watersheds (Runkel and Hippe, 2011), and does not allow user manipulations 
of software selected regression models. Each LOADEST model uses streamflow only, or a MLR with streamflow and turbidity (table 4). LOADEST also is limited in its ability to compute large amounts of unit value data, so a one hour timestep was used, which also was less than optimal considering the small size of the upstream watersheds. Watersheds, of the size in this study, typically have orders of magnitude differences in measured constituents over short periods and hysteretic responses of constituents to changing streamflows, and concentration peaks do not necessarily match peak streamflows (Runkel and Hippe, 2011), all of which make greater time resolutions inaccurate. Furthermore, flowonly models do not account for the hysteresis effect that is otherwise measured by turbidity sensors. Finally, there is no method to account for missing turbidity data in the LOADEST program. This makes LOADEST less optimal than methods described in this report based on Rasmussen and others (2009). Considering these factors, LOADEST-computed loads and associated confidence intervals should be considered less accurate than the primary method used, and only as another method to give a sense of the uncertainty inherent to sediment load computations.

\section{Turbidity Truncation}

Occasionally turbidity data were recorded above a sensor specific, maximum reporting limit, typically between 1,000 to 1,500 FNUs, herein described as "turbidity truncation." Turbidity truncation was observed at Banner Creek at M Rd. and Black Vermillion River above Centralia Lake. The actual peak sediment concentration was not estimated in final load computations, because truncation only occurred during small periods (table 5) and at two sites, Banner Creek at M Rd. and Black Vermillion River above Centralia Lake. Sediment loads were computed by interpolating slopes prior to and after truncated periods; this method increased annual sediment loads at Banner Creek at M Rd. from 5 to 7 percent, and Black Vermillion River above Centralia Lake from 0 to 2 percent; however because of the method of estimation, a large amount of uncertainty exists in these estimations, which led to their exclusion from final sediment load totals.

\section{Estimating Sediment Transport During Periods of Missing Turbidity Data}

Two methods were used to estimate loads during periods of missing turbidity data (because of equipment malfunction or excessive fouling during storms caused by sediment build-up in the housing pipe). During periods of steady flow, turbidity data was estimated based on simple linear interpolation of turbidity between known values. When flow changed during periods of missing turbidity, streamflow models were used to compute SSC (table 4; fig. 6) using methods described in "Regression Models." Normal and log-transformed regressions were evaluated, and picked based on statistical
Table 5. Turbidity truncation at study sites during March 2009 through September 2011.

\begin{tabular}{lc}
\hline Storm date & Total time truncated \\
\hline $3 / 9 / 2010$ & Banner Creek at M Rd. \\
$3 / 24 / 2010$ & 3 hours \\
$4 / 23 / 2010$ & 4 hours \\
$5 / 25 / 2011$ & 2 hours 45 minutes \\
$6 / 2 / 2011$ & 1 hour 45 minutes \\
\hline Black Vermillion River above Centralia Lake \\
\hline $6 / 1 / 2009$ & 4 hours \\
$6 / 15 / 2009$ & 1 hour \\
$5 / 7 / 2010$ & 3 hours \\
$5 / 10 / 2010$ & 1 hour \\
\hline
\end{tabular}

comparison. The same samples excluded from the turbiditybased regression models were excluded from the flow-based models.

Differences in computed SSC between turbidity-computed and discharge-computed methods sometimes produced different values of SSC because of differences in model equations (fig. 7). To "smooth" the transition of computed SSC values between methods, the discharge-based SSC was shifted to turbidity-computed SSC based on methods in Porterfield (1972) (fig. 7).

Turbidity was used to compute from 57 percent of the total loads (Black Vermillion River above Centralia Lake, 2011) to 100 percent of total loads (Atchison County Lake, entire study) (fig. 8). A water year starts on October 1 and ends September 30, to roughly match the annual hydrologic cycle. From this point forward, water years will be designated as only the year, for example 'water year 2009' will be hereafter denoted as '2009.' Turbidity sensors were operational from 100 percent of the time at Atchison Lake throughout the study to 89 percent of the time at Black Vermillion River below Centralia Lake during 2010 (fig. 8). Because turbidity sensor fouling occurred during some high flow periods, large percentages of flow-only load totals were calculated at sites upstream from Banner and Centralia Lakes.

SSC, computed by the two models covering the ranges of flows to which they were applied, indicate that at Clear Creek at Decatur Rd. (upstream from Atchison County Lake), discharge-computed SSC's typically were less than turbiditycomputed SSC's. At Banner Creek at M Rd., discharge-based SSC's typically were less at discharges below $150 \mathrm{ft}^{3} / \mathrm{s}$ and above $450 \mathrm{ft}^{3} / \mathrm{s}$. In-between these two ranges the variability is likely because of the lack of discharge-computed SSC's being utilized, and therefore few periods with similar discharges 


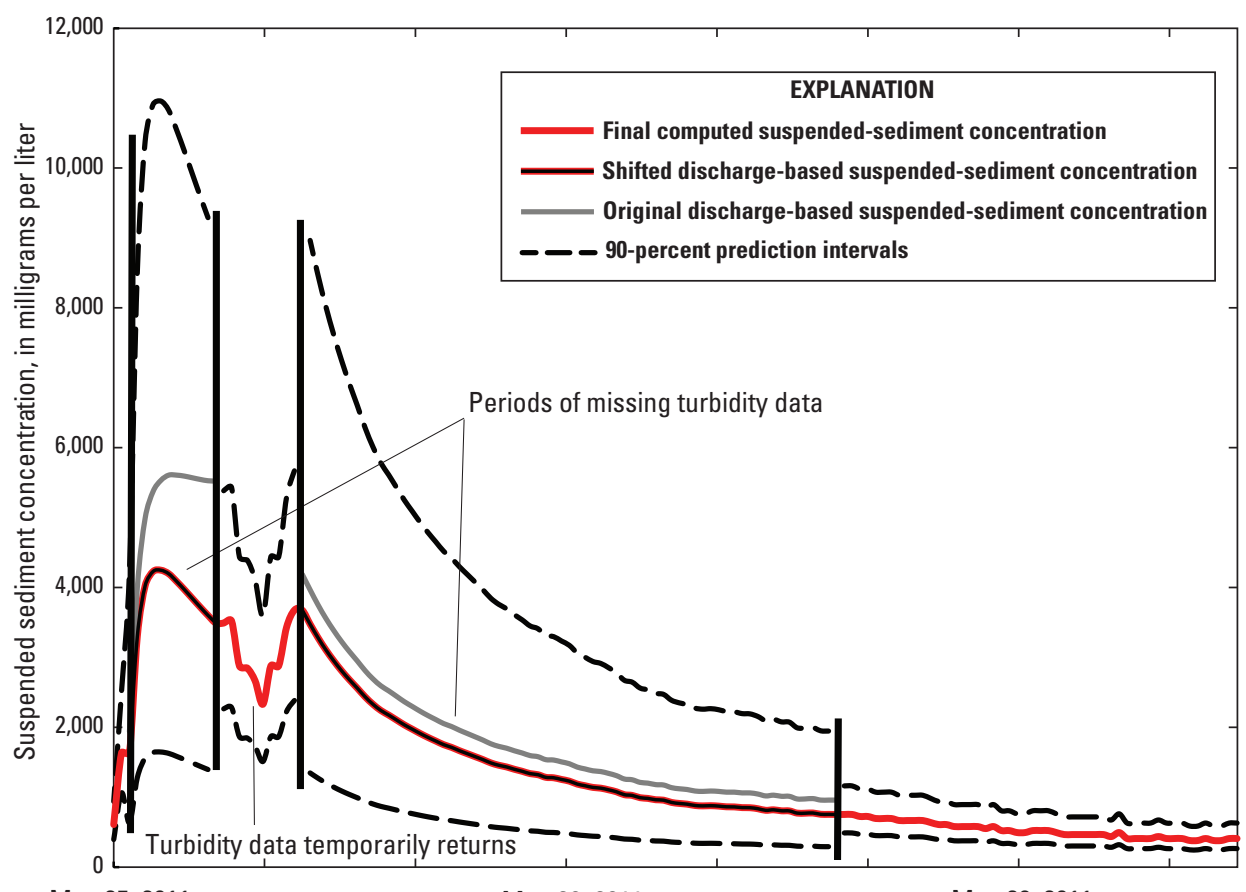

May 25, $2011 \quad$ May 26, 2011

May 26, 2011

Figure 7. Example hydrograph from Black Vermillion River above Centralia Lake showing differences between discharge- and turbidity-computed models, shifting results (Porterfield, 1972), and difference in prediction intervals between models during May 25-26, 2011.

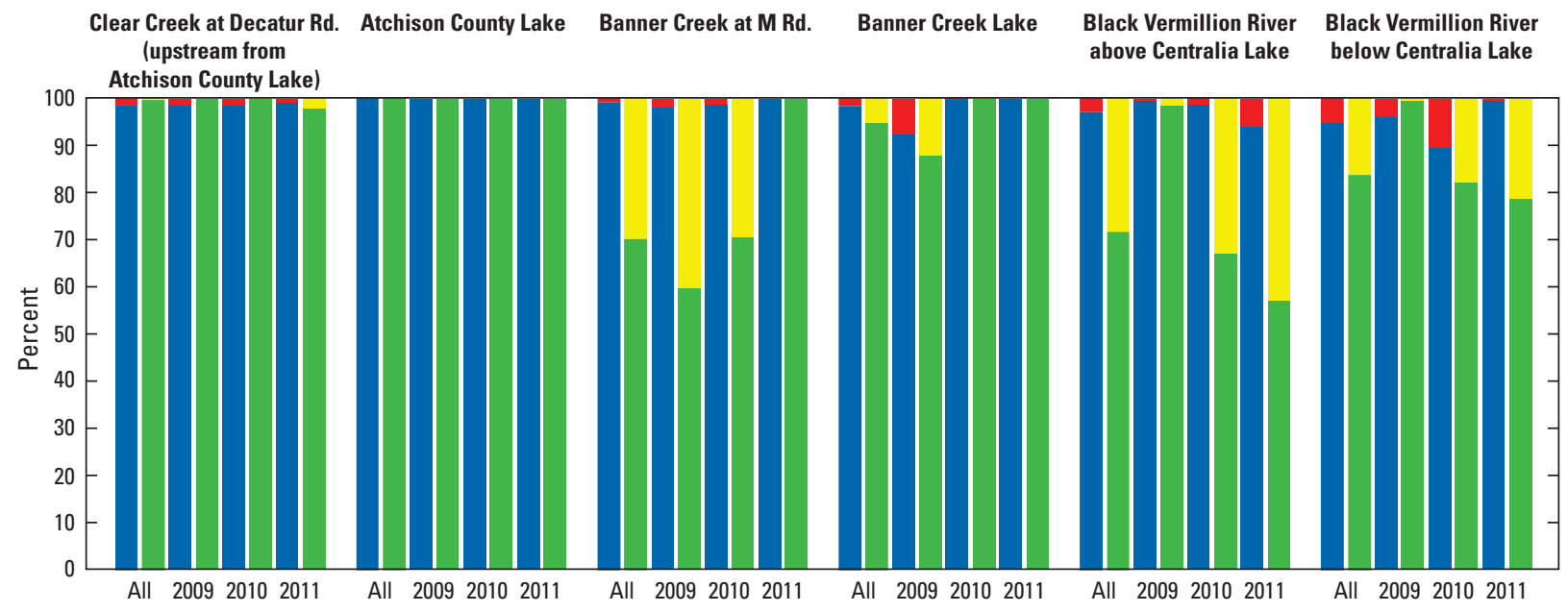

EXPLANATION

Percent of time flow-only regression model used

Percent of load computed by flow-only regression model

Percent of time turbidity-based regression model used

Percent of load computed by turbidity-based regression model

Figure 8. Percent of time each regression model was used and percent of total load computed by each model for each site during March 2009 through September 2011. 
in those ranges were available for comparison. At Black Vermillion River above Centralia Lake, discharge-based SSC's generally were less than turbidity-computed SSC's from 50 to $550 \mathrm{ft}^{3} / \mathrm{s}$. Above $550 \mathrm{ft}^{3} / \mathrm{s}$, discharge-computed SSC's had larger variability, but median values were somewhat higher than turbidity-computed SSC's. Because of this, loads computed using the shifted discharge-based models are likely less than those that would have been computed if turbidity data were available, especially at higher flows when most sediment load is transported.

\section{Collection, Analysis, and Computation of Sediment Loads at Selected Upstream Small Ponds}

\section{Pond Locations and Descriptions}

Sediment transport to and from two small (surface areas of approximately $0.013 \mathrm{mi}^{2}$ ) watershed ponds were studied to evaluate how these ponds affect sediment yields at upstream sediment sampling sites. Two small watershed ponds were selected upstream from Atchison County Lake watershed based on drainage area and land owner permission (fig. 2). The two sites selected (fig. 2; table 6) were Little Delaware Mission Dam 5 (LDMD 5) and Little Delaware Mission Dam 17 (LDMD 17). LDMD 5 drains $0.78 \mathrm{mi}^{2}$ and LDMD 17 drains $0.77 \mathrm{mi}^{2}$. These two Atchison ponds drain 22 percent of the drainage area upstream from the USGS Clear Creek at Decator
Rd. (upstream from Atchison Lake) site, which is 17 percent of the total watershed.

LDMD 5 was constructed in 1967 and drains land used for pasture and row crops (fig. 2). During April through August 2011, soybeans and corn were planted in the surrounding fields, and livestock were frequently present. A grass buffer of at least $60 \mathrm{ft}$ surrounded the pond. The outflow structure was a vertical corrugated steel pipe of $2.5 \mathrm{ft}$ diameter with a top elevation of $1,109.80 \mathrm{ft}$ above North American Vertical Datum of 1988 (NAVD 88).

LDMD 17 was constructed in 1967 and drains land used for row crops (fig. 2). During the period of study, the surrounding fields were planted (soybeans), and no livestock were observed near the pond. A grass buffer of $50 \mathrm{ft}$ was planted at the beginning of the data collection period; no buffer existed before this. The grass buffer did not become fully established during the period studied. The outflow structure was a vertical corrugated steel pipe of $2.5 \mathrm{ft}$ diameter with a top elevation of $1,110.39 \mathrm{ft}$ above NAVD 88 .

\section{Spatial Analysis of Selected Ponds}

The two pond sites were surveyed using a Trimble R8 Global Navigation Satellite System (GNSS) survey-grade Global Positioning System (GPS) to obtain estimates of pond volume. A total of 370 points were surveyed for the LDMD 5 site, whereas 294 points were surveyed for LDMD 17. Elevations were surveyed above the water level on the survey date; no bathymetric data were collected.

Table 6. Location and contributing drainage area of small pond gaging sites in the Atchison watershed, northeast Kansas during March 2009 through September 2011.

[mi², square miles; LDMD, Little Delaware Mission Dam]

\begin{tabular}{|c|c|c|c|c|}
\hline $\begin{array}{l}\text { U.S. Geological } \\
\text { Survey identifica- } \\
\text { tion number }\end{array}$ & Station name & $\begin{array}{l}\text { Contributing } \\
\text { drainage } \\
\text { area } \\
\left(\mathrm{mi}^{2}\right)\end{array}$ & $\begin{array}{l}\text { Latitude } \\
\text { (degrees, } \\
\text { minutes, } \\
\text { seconds) }\end{array}$ & $\begin{array}{c}\text { Longitude } \\
\text { degrees, } \\
\text { minutes, } \\
\text { seconds) }\end{array}$ \\
\hline 393851095244300 & LDMD 5 Lake Outflow above Atchison Lake near Horton, Kansas ${ }^{1}$ & 0.78 & $39^{\circ} 38^{\prime} 51^{\prime \prime}$ & $95^{\circ} 27^{\prime} 43^{\prime \prime}$ \\
\hline 393851095244100 & LDMD 5 Lake above Atchison Lake near Horton, Kansas² & 0.78 & $39^{\circ} 38^{\prime} 51^{\prime \prime}$ & $95^{\circ} 27^{\prime} 41^{\prime \prime}$ \\
\hline 393813095243300 & LDMD 17 Lake North Inflow above Atchison Lake near Horton, Kansas ${ }^{1}$ & 0.32 & $39^{\circ} 38^{\prime} 13^{\prime \prime}$ & $95^{\circ} 24^{\prime} 33^{\prime \prime}$ \\
\hline 393809095244200 & LDMD 17 Lake Outflow above Atchison Lake near Horton, Kansas ${ }^{1}$ & 0.77 & $39^{\circ} 38^{\prime} 09^{\prime \prime}$ & $95^{\circ} 24^{\prime} 42^{\prime \prime}$ \\
\hline 393809095244000 & LDMD 17 Lake above Atchison Lake near Horton, Kansas² & 0.77 & $39^{\circ} 38^{\prime} 09^{\prime \prime}$ & $95^{\circ} 24^{\prime} 40^{\prime \prime}$ \\
\hline
\end{tabular}

${ }^{1}$ Site number used for lake water-quality monitor.

${ }^{2}$ Site number used for continuous lake elevation. 
Survey data (in feet) were imported into ArcGIS Geographic Information System (GIS) software (ESRI, 2011). These data were then converted to Triangulated Irregular Networks (TINs), which connect all survey points with triangular planes. Grids were then created at multiple specific elevations, and overlaid on the TIN to simulate various water surface elevations. The differences between the ground elevation and water level were then calculated using a "cut/ fill" operation, which yielded tables for elevation-area, raw elevation-volume, and elevation-volume above the outflow pipe opening. Raw volumes are defined by how ArcGIS interpolated the impoundment elevation during TIN creation, and can be inaccurate because of interpolations below the water surface, which was not surveyed. The raw volume data was subtracted from the outflow elevation-volume to produce volume above the outflow pipe.

LDMD 5 survey data were not sufficient to cover the full range of expected impoundment elevations. Recent Light, Detection, and Ranging (lidar) data were available through the Kansas GIS website (www.kansasgis.org) and were used to fill in missing areas. The horizontal grid spacing of the lidar data was $1.4 \mathrm{~m}$ and vertical bare earth resolution of $1 \mathrm{~m}$ (Kansas Data Access and Support Center, 2011). The lidar data were converted to a TIN, then to an appropriately sized raster containing elevation data. Several ArcGIS tools (Spatial Analyst, 3D Analyst; ESRI, 2011) were then employed to convert these into $x-y-z$ point data. The new spatial-elevation data were appended to the original survey file.

\section{Data Collection for Selected Small Ponds}

To calculate pond trapping efficiency, it was necessary to compute a continuous record of incoming and outgoing streamflow and SSC. Impoundment elevation and turbidity were used to compute these parameters. Each pond was gaged for elevation near the outflow structure using Solinst "LevelLogger Gold" submersible pressure transducers. Fluctuations in elevation data caused by changes in atmospheric pressure were corrected by using a recording barometer Solinst "Barologger Gold" installed near the impoundments. The correction for atmospheric pressure was applied using Solinst software (Solinst, 2007). Elevation data were verified during each site visit using standard USGS stage measurement techniques (Sauer and Turnipseed, 2010). Turbidity data were collected using YSI 6136 turbidity sensors deployed near the outflow structure and near the impoundment inflow (in the case of LDMD 17, both inflows).

To ensure the best resolution of data relative to the small watershed size, 5-minute recording intervals were used on all sensors. Site visits to clean sensors, verify impoundment elevations, and download data were made approximately every 2 weeks. Measurements of flow or SSC were not verified because of the rapid, high variability of the stormflow and driving distance to the sites. All computed discharges at the two ponds should be considered estimates.

\section{Pond Data Analysis Techniques}

Because each impoundment had a static outflow structure, only impoundment elevation and a corresponding stagestorage relation were needed to calculate flow into and out of each pond. Outflow was computed based on the hydraulic characteristics of the outflow structure and inflow was computed using a continuity routing equation (equation 1):

$$
\begin{aligned}
\text { Inflow }_{2} & =\left(\frac{2 \text { Storage }_{2}}{\Delta \text { time }}+\text { Outflow }_{2}\right)-\left(\frac{2 \text { Storage }_{1}}{\Delta \text { time }}+\text { Outflow }_{1}\right) \\
& - \text { Inflow }_{1}+2 \text { Outflow }_{1}
\end{aligned}
$$

Where inflow ${ }_{2}$ is the discharge in cubic feet per second $\left(\mathrm{ft}^{3} / \mathrm{s}\right)$ at time 2 , storage ${ }_{2}$ is the volume in acre-feet (acre-ft) at time 2 as determined by stage-volume tables, $\Delta$ time is the time difference between recording intervals in seconds (s), outflow ${ }_{2}$ is the outflow discharge in cubic feet per second at time 2 based on outflow hydraulics, storage ${ }_{1}$ is the pond volume in acre- $\mathrm{ft}$ at time 1 , outflow ${ }_{1}$ is the outflow discharge in cubic feet per second at time 1, and inflow ${ }_{1}$ is the inflow discharge in cubic feet per second as computed from the previous time-step.

Flow equations based on weir flow $\left(Q_{\text {weir }}\right)$ and orifice flow $\left(Q_{\text {orifce }}\right)$ were applied, depending on water elevation above the riser, to compute outflow discharge (equations 2, 3; U.S. Bureau of Reclamation, 1987).

$$
\begin{gathered}
Q_{\text {weir }}=C_{w} \pi d h^{\frac{3}{2}} \\
Q_{\text {orifice }}=C_{c} \frac{\pi d^{2}}{4} \sqrt{2 g h}
\end{gathered}
$$

Where $C_{w}$ is the graphically determined circular crest coefficient (U.S. Bureau of Reclamation, 1987), $C_{c}$ is the coefficient of contraction ( 0.5 for a sharp crest), $d$ is the pipe diameter in decimal-feet, $h$ is the water elevation above the inlet in decimal-feet, $g$ is gravity in feet per second squared $\left(\mathrm{ft} / \mathrm{s}^{2}\right)$, and both $Q$ terms are in cubic feet per second.

Anomalies caused by wave action are visible in the elevation record as large oscillations in stage that did not follow the general trend of the hydrograph. These anomalies in the stage data were deleted, and the missing data during periods without precipitation were estimated by simple linear interpolation. Also, pressure transducers are prone to a slight drift in time. To compensate for this, the pond elevation data were corrected based on field visit verification of elevation by applying an increasing or decreasing correction between known, fieldverified elevations. 
Initial computed inflows exhibited large, instantaneous increases and decreases in discharge because of the $0.02-\mathrm{ft}$ resolution of impoundment elevation data, which was recorded at 0.01 -ft intervals $( \pm 0.02 \mathrm{ft})$, and storage, and was estimated based on elevation-storage tables that ranged from 0.08 to 0.21 acre-ft difference for $0.01-\mathrm{ft}$ change in elevation. This oscillation was amplified during windy days that caused wave action, resulting in erratic impoundment elevation. A movingaverage smoothing function was applied to the elevation record to address these oscillations.

SSC was computed using YSI 6136 turbidity sensor data and regression procedures outlined in Rasmussen and others (2009). The regression developed for Clear Creek at Decatur Rd. (upstream from Atchison County Lake) (table 4) was used for SSC calculations in the Atchison watershed, because Lee and Ziegler (2010b) indicated that turbiditySSC relations within the same watershed remain constant because of similarities in soil type in northeast Kansas. A possible source of error in this study is turbidity truncation. Turbidity truncation was observed at the LDMD 17 south inflow during several recorded storm events. The actual peak suspended-sediment concentration was not estimated in final load totals, because truncation only occurred during a small period (a total of 1 hour and 55 minutes during one 5-hour storm, 40 minutes during two other storm events, both which lasted approximately 1 hour and 15 minutes, both based on inflow hydrograph), and estimations based on interpolating slopes prior to and after truncated periods are prone to large uncertainty. These estimations increased loads roughly 3 to 22 percent when truncated peaks were visual by hydrographic fitting. Because these estimates are qualitative, they are not included in final load computations; however, it is possible that incoming loads were approximately 10 percent higher than computed loads.

LDMD 17 had two inflow streams, hereinafter referred to as north fork (NF) and south fork (SF). Delineation of each inlet in GIS indicated NF drained 46.5 percent of the LDMD 17 watershed, and the SF the other 53.5 percent. For inflow calculations, total inflow was split according to each inlet's percentage of the total drainage area. During one storm, which affected LDMD 17 from May 31 to June 6, 2011, both inlets experienced long periods of missing turbidity data because of sensor malfunction or fouling at different times during the event. To account for the missing data, the missing data from one inflow tributary was set to be equal to the existing data from the other inflow tributary, and the subsequent computed loads were adjusted by percent drainage area. Because recorded turbidity values were not always equal during storms, if both sensors were operational, a large but unknown amount of error was inherent to this method of estimation during periods of missing turbidity data at LDMD 17.

\section{Characterization of Sediment Transport to and from Small Impoundments in Northeast Kansas}

\section{Hydrologic Conditions}

\section{Precipitation}

Annual precipitation data during 2009 at Atchison Lake and Banner Creek Lake watersheds and at all three watersheds in 2010 were larger than the mean annual precipitation as recorded by nearby meteorological stations (National Oceanic and Atmospheric Administration, 2012) over the stations' period of record. The meteorological station operated by the National Weather Service (NWS) at Horton, Kansas (near the Atchison Lake watershed) recorded 43.2 in. during 2009 and 47.7 in. during 2010, as compared to a long-term mean annual precipitation total of 35.6 in. (fig. 9). The meteorological station run by the NWS at Holton, Kansas (near the Banner Lake watershed) recorded 38.9 in. during 2009 and $41.6 \mathrm{in}$. during 2010 , as compared to a long-term mean annual precipitation total of 35.2 in. (fig. 9). The meteorological station run by the NWS at Baileyville, Kansas (near the Centralia Lake watershed, NWS site number 00140482 , there was no precipitation gage at the Centralia 00141408 NWS station) did not record a complete record during 2009, but did record 35.8 in. during 2010, as compared to a long-term mean annual precipitation total of 33.8 in. (fig. 9). Lower than average precipitation was recorded at Banner and Centralia watersheds by the NWS during 2011 with 27.4 in. at Holton (mean annual 35.2 in.) and 21.6 in. at Baileyville (mean annual 33.8 in.) (fig. 9). Only Atchison had slightly above average precipitation during 2011 with 36.2 in. at Horton (mean annual 35.6 in.).

\section{Streamflow}

No historical data exist for the study sites to determine long term mean streamflows to compare to those observed during the study. Because data collection began in March 2009,2009 is based on only one-half of that year's length, but it is still referred to as "2009" in this report. Because of this, calculated flow totals for 2009 are lower than when taken in comparison to the following complete years of data (fig. 10). Duration curves, which graphically represent the relation between the magnitude and frequency of streamflow during a period of time, were computed for March 2009 through September 22, 2011 (fig. 11). The lack of streamflow data during the lower flow, winter months in beginning of 2009 


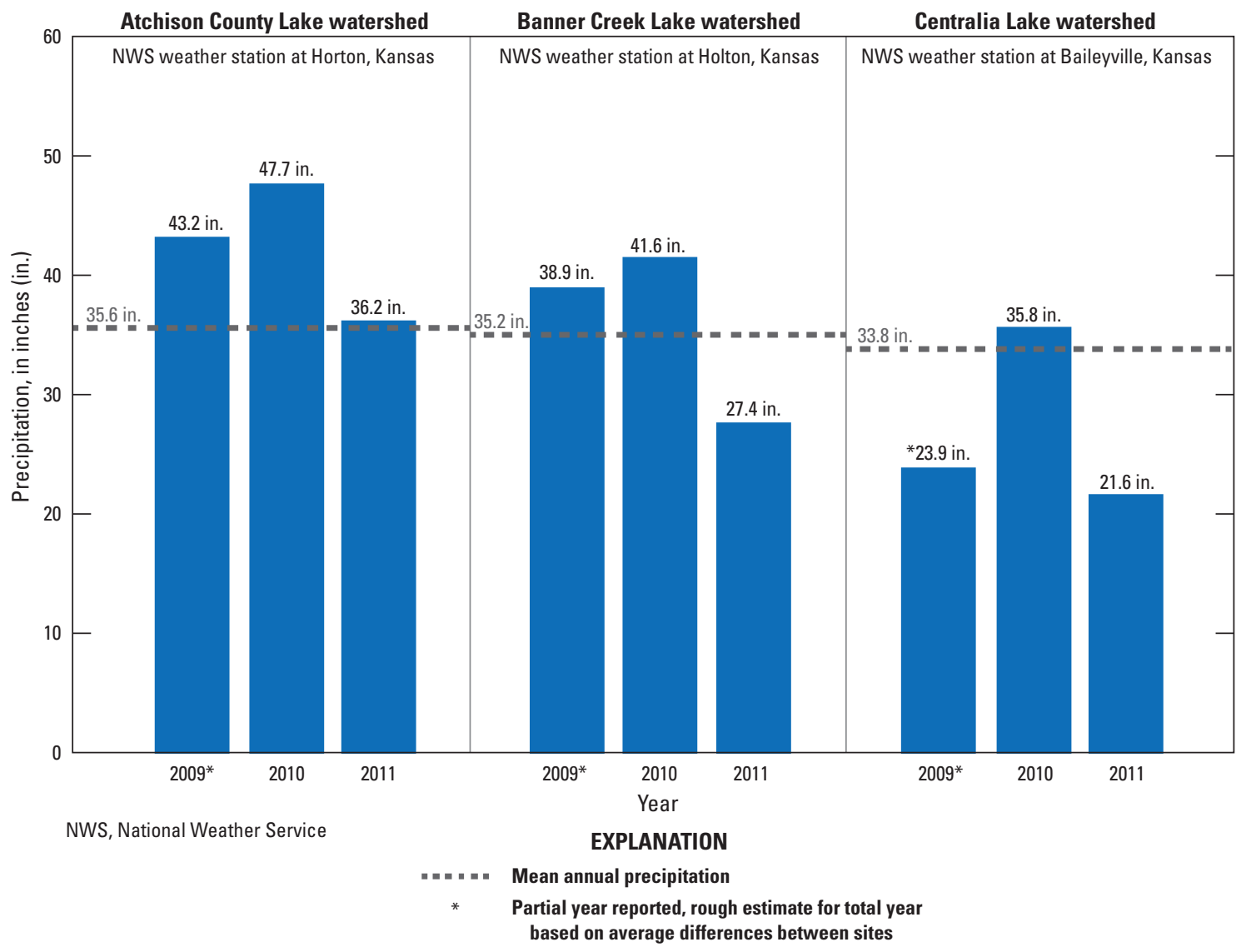

Figure 9. Annual precipitation totals recorded by National Weather Service meteorological monitoring stations.

likely bias these durations toward high flows compared to normal conditions. The greatest streamflows were generally in 2010 and the lowest in 2011, which corresponds with observed rainfall totals. The Centralia watershed was the exception because of several large storms in late May and early June 2011 that produced 62 percent of that year's flow.

Total flow into the lakes from March 2009 to September 2011, including the estimated flow for the ungaged part of the watershed, was 15,000, 20,500, and 18,000 ac-ft for Atchison, Banner, and Centralia Lake watersheds, respectively (fig. 10). During that time 17,000, 18,000, 13,000 ac-ft of water was released from Atchison, Banner, and Centralia Lake, respectively. Lower outflow totals at Banner and Centralia compared to total inflows can be explained by evaporation, or seepage to groundwater. Evaporation and seepage losses from Banner Lake and Centralia Lake are likely a larger percentage of water loss than Atchison County Lake because Banner Lake and Centralia Lake are larger relative to upstream drainage area, and thus have longer residence times (residence time is the amount a given unit of water will remain in the lake). However, larger outflows than inflows from Atchison County
Lake could be explained by a combination of increased rainfall and runoff from the ungaged part of the upstream watershed, and tile drains draining subsurface water into the lake downstream from the Clear Creek at Decator Rd. streamgage (fig. 10).

Duration curves (fig. 11) for each upstream sample site indicate that the greatest streamflow at 99-percent exceedance was at Banner with $0.08 \mathrm{ft}^{3} / \mathrm{s}$, as compared to Atchison and Centralia, which had 99-percent exceedance of $0.01 \mathrm{ft}^{3} / \mathrm{s}$. This indicates that Banner, which was the largest watershed, had higher baseflow volumes during the period of the study, likely because of more contributions from groundwater. During the entire study period, frequencies of exceedance greater than 1 percent (approximately 9.3 days), accounted for 40 , 34 , and 50 percent of the total flows during the period of the study for Atchison Lake, Banner Lake, and Centralia Lake watersheds, respectively. Distributions of 1-percent frequency of exceedance during each individual year (approximately 2 days for partial 2009, approximately 3.6 days for 2010 and 2011) for each watershed are 44,32 , and 44 percent for each year, respectively, at Atchison; 31, 27, and 41 percent for each year, respectively, at Banner; and 40, 41, and 66 percent for 


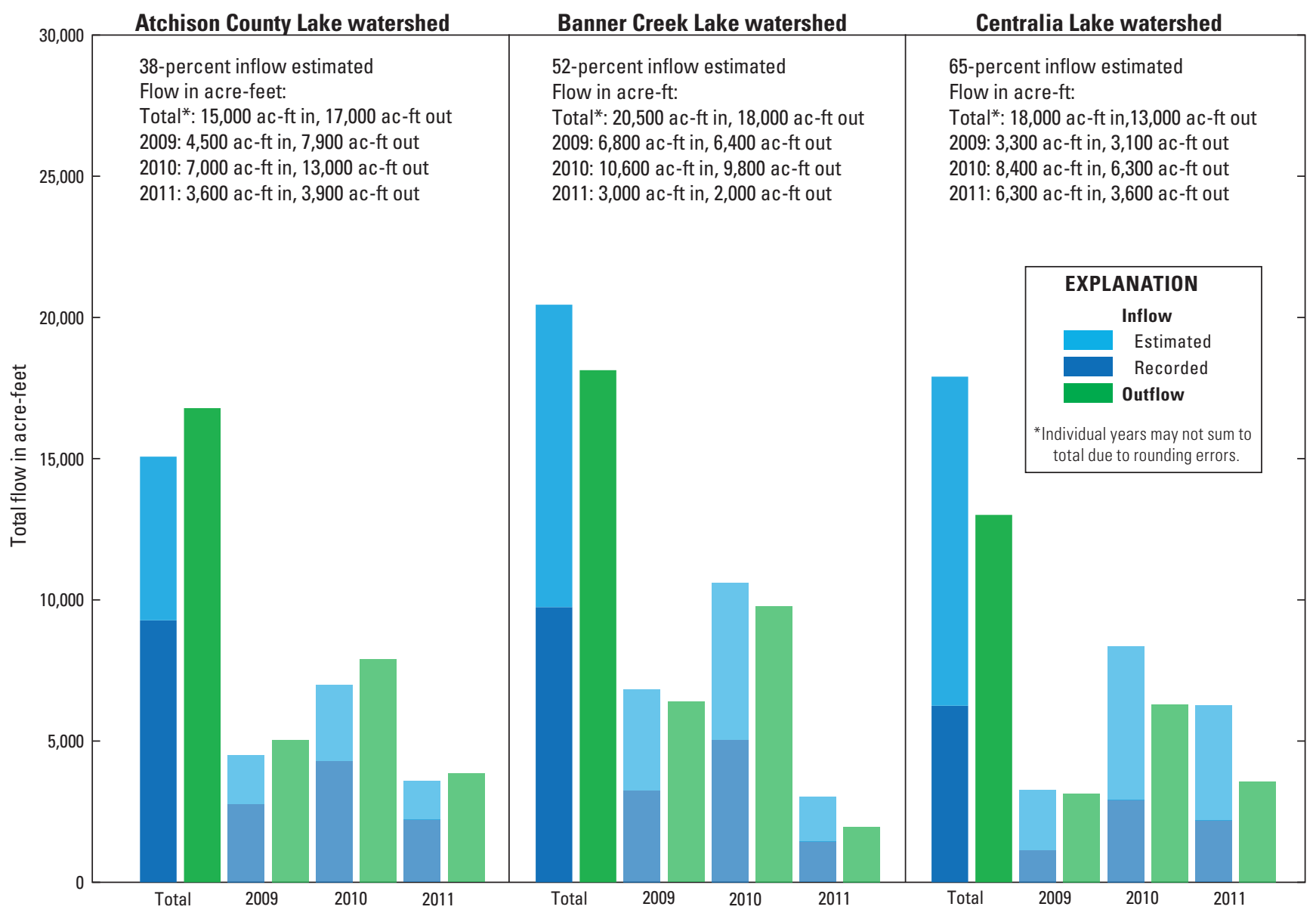

Figure 10. Computed and estimated streamflow into and from each lake for study period during March 2009 through September 2011.

each year, respectively, at Centralia. The more gradual rise of the duration curve between 10- to 1-percent exceedances at Clear Creek (upstream from Atchison County Lake) compared with the other two sites could be because of upstream impoundments and tile retaining storm-flows and releasing them at more steady rates than if the watershed was without the impoundments.

\section{Sediment Transport}

Sediment samples collected at study sites indicated most of the suspended-sediments were comprised of silts and clays (table 7). Sediment transport into each of the three study watersheds during the study period, including the estimated ungaged parts, was 9,700; 23,000; and 35,700 tons at Atchison, Banner, and Centralia, respectively (fig. 12). Transport from study impoundments was 3,000 tons from Atchison, 360 tons from Banner, and 780 tons from Centralia during the duration of the study. LOADEST-computed transport and 95-percent confidence intervals for upstream gaging sites also are plotted on figure 12, and indicate greater sediment transport at Centralia compared with the other two watersheds.
To evaluate how sediment was transported, suspendedsediment duration curves were plotted for each upstream gaging site during the entire period of the study (fig. 13). Upstream from Atchison County, Banner Creek, and Centralia Lakes 73,85 , and 84 percent of the total load was transported during less than 1 percent (approximately 9 days) of the time (fig. 13). Upstream from Atchison County, Banner Creek, and Centralia Lakes 24, 38, and 32 percent of the total load was transported during less than 0.1 percent (approximately 0.9 days) of the time (fig. 13). Ninety-three percent of total transport at less than 1-percent exceedance occurred at Centralia during 2011, which was the year with the least annual precipitation. This large load was because of strong storms from May 24 to June 19, 2011 (field personnel noted the fields recently were planted throughout the watershed), which transported 11,200 tons, or 71 percent, of the 15,700 tons of sediment total for the year (31 percent of the sediment transport computed during the entire study). The same storm system at Banner transported 3,060 tons of the 3,140 tons of sediment total for 2011, or 97 percent (13 percent of the sediment transport computed during the entire study). 


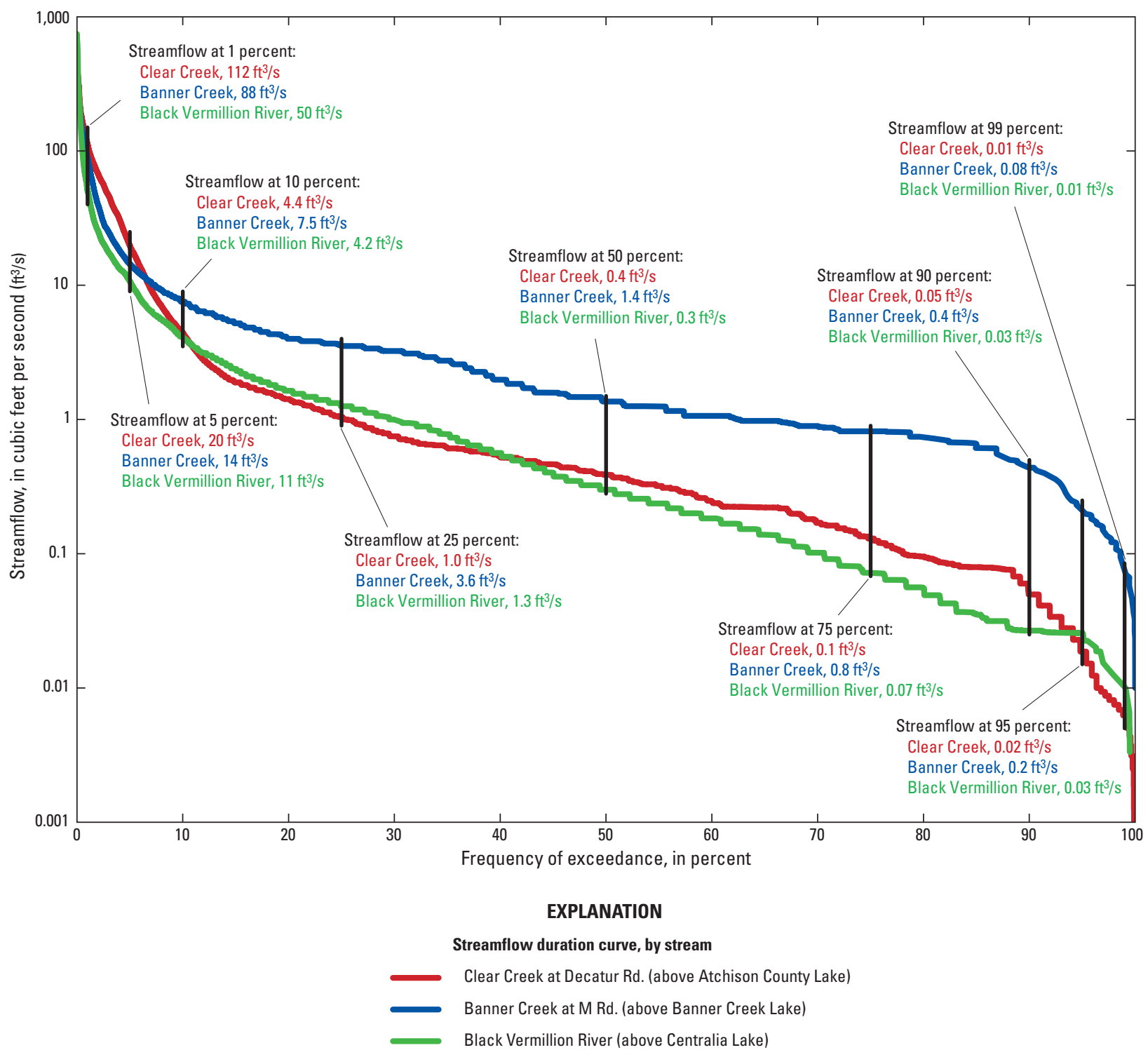

Figure 11. Streamflow duration curves for study sites upstream from lakes during March 2009 through September 2011.

\section{Trapping Efficiencies}

Trapping efficiencies for each of the three study lakes range from 72 percent at Atchison County Lake and 98 percent for Banner Creek and Centralia Lakes during the entire study (fig. 14). Trapping efficiencies remained at 98 percent or greater for Banner Creek and Centralia Lakes each year recorded. These lakes are large relative to watershed drainage area and because outlet discharge is small, sediment remains in the lake longer (longer residence time) and settles to the lake bottom. Flow through Banner Creek and Centralia Lakes was constrained by the outlet structure over the duration of the study. Flow at Atchison County Lake was primarily through a small outlet structure, but during high flow events flow was diverted over an emergency spillway, which greatly increased the outflow discharge. At the maximum observed lake volumes (Kansas Biological Survey, 2010a, b, c) with corresponding maximum computed outlet discharges, residence times were approximately 6 hours at Atchison, 14 days at Banner, and 11 days at Centralia. Atchison County Lake, built in 1935, besides having been built with a smaller volume than Banner Creek and Centralia Lakes, has mostly silted in, resulting in a smaller volume and lower residence times as discussed in "Streamflow." Trapping efficiencies at Atchison County Lake ranged from 64 to 84 percent for each year during the study period (fig. 14), with the greatest trapping efficiency during 2011, which corresponds to the year with the lowest annual flow volume, and fewer high flow events that topped the emergency spillway. 
Table 7. Suspended-sediment concentration and percent silt/clay (<63 micrometers diameter) from discrete samples collected from study sites during March 2009 through September 2011.

[mg/L, milligrams per liter; FNU, Formazin Nepholemetric Units; $\mathrm{ft}^{3} / \mathrm{s}$, cubic foot per second; <, less than; $\mu \mathrm{m}$, micrometer]

\begin{tabular}{|c|c|c|c|c|c|c|c|c|c|}
\hline $\begin{array}{l}\text { Sample } \\
\text { date }\end{array}$ & $\begin{array}{c}\text { Suspended- } \\
\text { sediment } \\
\text { concentration } \\
\text { (mg/L) }\end{array}$ & $\begin{array}{c}\text { In-situ } \\
\text { turbidity } \\
\text { (FNU) }\end{array}$ & $\begin{array}{c}\text { Streamflow } \\
\left(\mathrm{ft}^{3} / \mathrm{s}\right)\end{array}$ & $\begin{array}{c}\text { Percent } \\
\text { silt/clay } \\
<63 \mu \mathrm{m}\end{array}$ & $\begin{array}{l}\text { Sample } \\
\text { date }\end{array}$ & $\begin{array}{c}\text { Suspended- } \\
\text { sediment } \\
\text { concentration } \\
\text { (mg/L) }\end{array}$ & $\begin{array}{c}\text { In-situ } \\
\text { turbidity } \\
\text { (FNU) }\end{array}$ & $\begin{array}{c}\text { Streamflow } \\
\left(\mathrm{ft}^{3} / \mathrm{s}\right)\end{array}$ & $\begin{array}{c}\text { Percent } \\
\text { silt/clay } \\
<63 \mu \mathrm{m}\end{array}$ \\
\hline $3 / 24 / 2009$ & 481 & 320 & 78 & 99 & $7 / 21 / 2010$ & 86 & 76 & 4.3 & 98 \\
\hline 4/9/2009 & 28 & 10 & 0.86 & 78 & $9 / 1 / 2010$ & 110 & 96 & 0.04 & 99 \\
\hline $4 / 28 / 2009$ & 314 & 250 & 51 & 99 & $11 / 3 / 2010$ & 113 & 120 & 0.19 & 100 \\
\hline $6 / 11 / 2009$ & 614 & 360 & 131 & 99 & $11 / 30 / 2010$ & 83 & 53 & 2.2 & 99 \\
\hline $6 / 29 / 2009$ & 50 & 37 & 0.13 & 98 & $3 / 25 / 2011$ & 35 & 29 & 1.9 & 99 \\
\hline $8 / 10 / 2009$ & 113 & 84 & 0.46 & 98 & $5 / 26 / 2011$ & 99 & 70 & 20 & 99 \\
\hline $8 / 17 / 2009$ & 941 & 480 & 243 & 99 & $6 / 2 / 2011$ & 107 & 97 & 222 & 99 \\
\hline $8 / 17 / 2009$ & 314 & 170 & 90 & 89 & $3 / 24 / 2009$ & 705 & 390 & 32 & 97 \\
\hline $10 / 15 / 2009$ & 50 & 9.5 & 0.1 & 63 & $4 / 10 / 2009$ & 1,000 & 490 & 12 & 99 \\
\hline $10 / 22 / 2009$ & 69 & 50 & 8.1 & 99 & $4 / 27 / 2009$ & 798 & 400 & 165 & 99 \\
\hline $3 / 25 / 2010$ & 168 & 110 & 14 & 98 & 4/30/2009 & 758 & 440 & 64 & 98 \\
\hline $4 / 23 / 2010$ & 241 & 140 & 71 & 99 & 6/9/2009 & 490 & 320 & 6.4 & 99 \\
\hline $6 / 14 / 2010$ & 192 & 130 & 30 & 97 & $6 / 15 / 2009$ & 755 & 430 & 20 & 95 \\
\hline $9 / 1 / 2010$ & 154 & 120 & 0.18 & 97 & 8/10/2009 & 99 & 14 & 1.4 & 79 \\
\hline $9 / 22 / 2010$ & 269 & 170 & 84 & 99 & $8 / 17 / 2009$ & 565 & 350 & 12 & 96 \\
\hline $11 / 3 / 2010$ & 8 & 6.8 & 0.39 & 93 & $9 / 21 / 2009$ & 73 & 33 & 2.3 & 55 \\
\hline $4 / 10 / 2009$ & 152 & 120 & 122 & 98 & $4 / 22 / 2010$ & 346 & 160 & 11 & 97 \\
\hline $4 / 28 / 2009$ & 309 & 300 & 72 & 99 & $4 / 22 / 2010$ & 595 & 260 & 37 & 95 \\
\hline $5 / 18 / 2009$ & 210 & 230 & 7.3 & 100 & $4 / 23 / 2010$ & 1,820 & 480 & 103 & 93 \\
\hline $6 / 11 / 2009$ & 438 & 360 & 320 & 100 & $6 / 14 / 2010$ & 226 & 94 & 18 & 94 \\
\hline $7 / 17 / 2009$ & 120 & 97 & 4.6 & 99 & $9 / 1 / 2010$ & 881 & 500 & 21 & 97 \\
\hline $8 / 10 / 2009$ & 34 & 49 & 2.9 & 93 & $11 / 3 / 2010$ & 4 & 0.4 & 1.2 & 68 \\
\hline $8 / 21 / 2009$ & 124 & 120 & 7.4 & 99 & $3 / 24 / 2011$ & 16 & 0.4 & 1.4 & 40 \\
\hline $10 / 15 / 2009$ & 12 & 13 & 0.01 & 93 & $5 / 24 / 2011$ & 241 & 130 & 6.8 & 99 \\
\hline $10 / 22 / 2009$ & 22 & 22 & 0.01 & 97 & $5 / 25 / 2011$ & 1,970 & 1,130 & 59 & 93 \\
\hline $3 / 25 / 2010$ & 128 & 110 & 54 & 99 & $6 / 2 / 2011$ & 3,020 & 880 & 241 & 74 \\
\hline $4 / 22 / 2010$ & 107 & 69.5 & 0.75 & 99 & \multicolumn{5}{|c|}{ Banner Creek Lake } \\
\hline $4 / 23 / 2010$ & 61 & 84.2 & 287 & 99 & $3 / 17 / 2009$ & 9 & 2.5 & 0.88 & 76 \\
\hline $5 / 25 / 2010$ & 64 & 54 & 3.4 & 98 & $3 / 24 / 2009$ & 30 & 20 & 21 & 96 \\
\hline $6 / 14 / 2010$ & 49 & 47 & 5.3 & 97 & $4 / 10 / 2009$ & 23 & 6.9 & 30 & 74 \\
\hline
\end{tabular}


Table 7. Suspended-sediment concentration and percent silt/clay (<63 micrometers diameter) from discrete samples collected from study sites during March 2009 through September 2011.-Continued

[mg/L, milligrams per liter; FNU, Formazin Nepholemetric Units; $\mathrm{ft}^{3} / \mathrm{s}$, cubic foot per second; <, less than; $\mu \mathrm{m}$, micrometer]

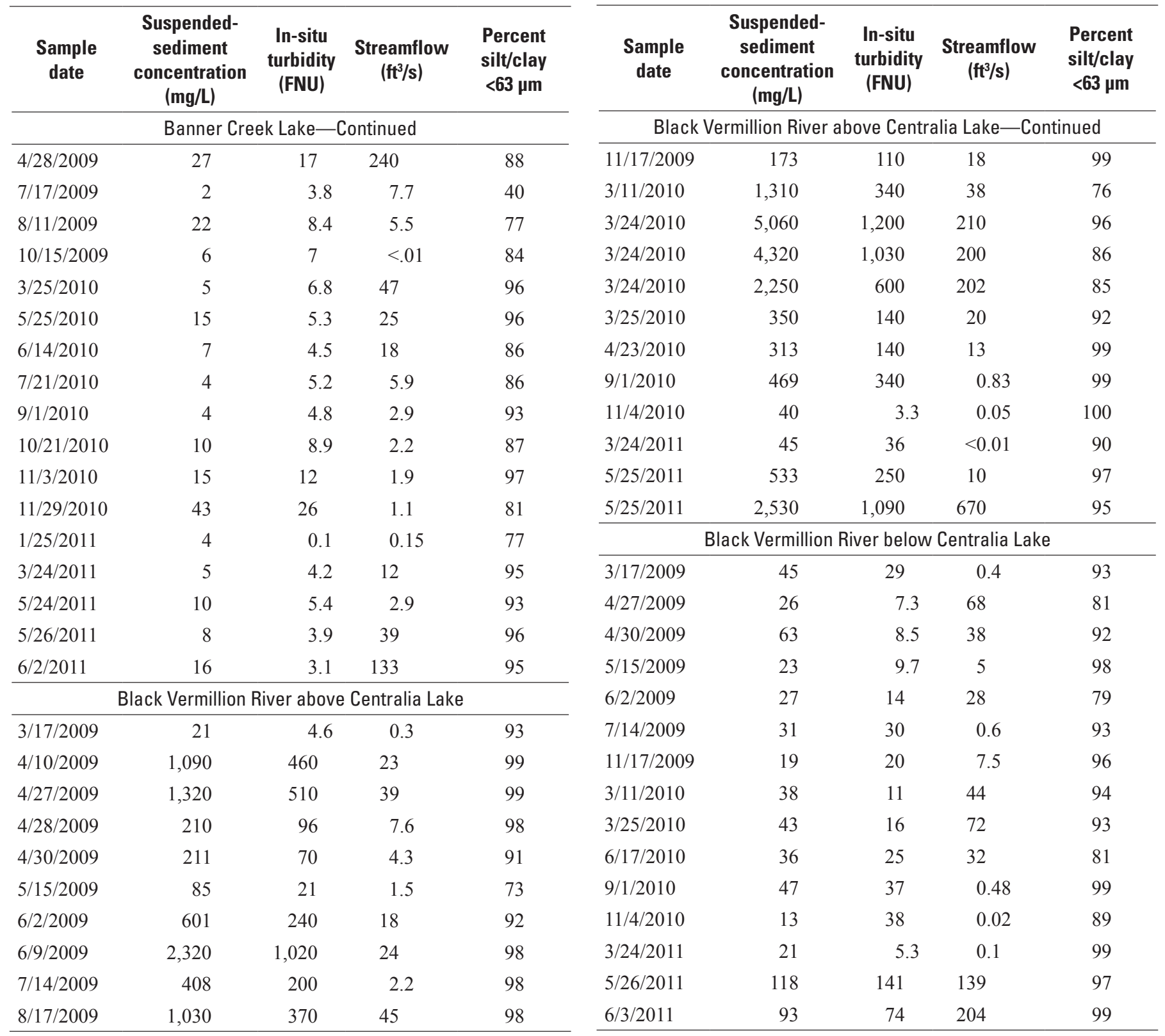




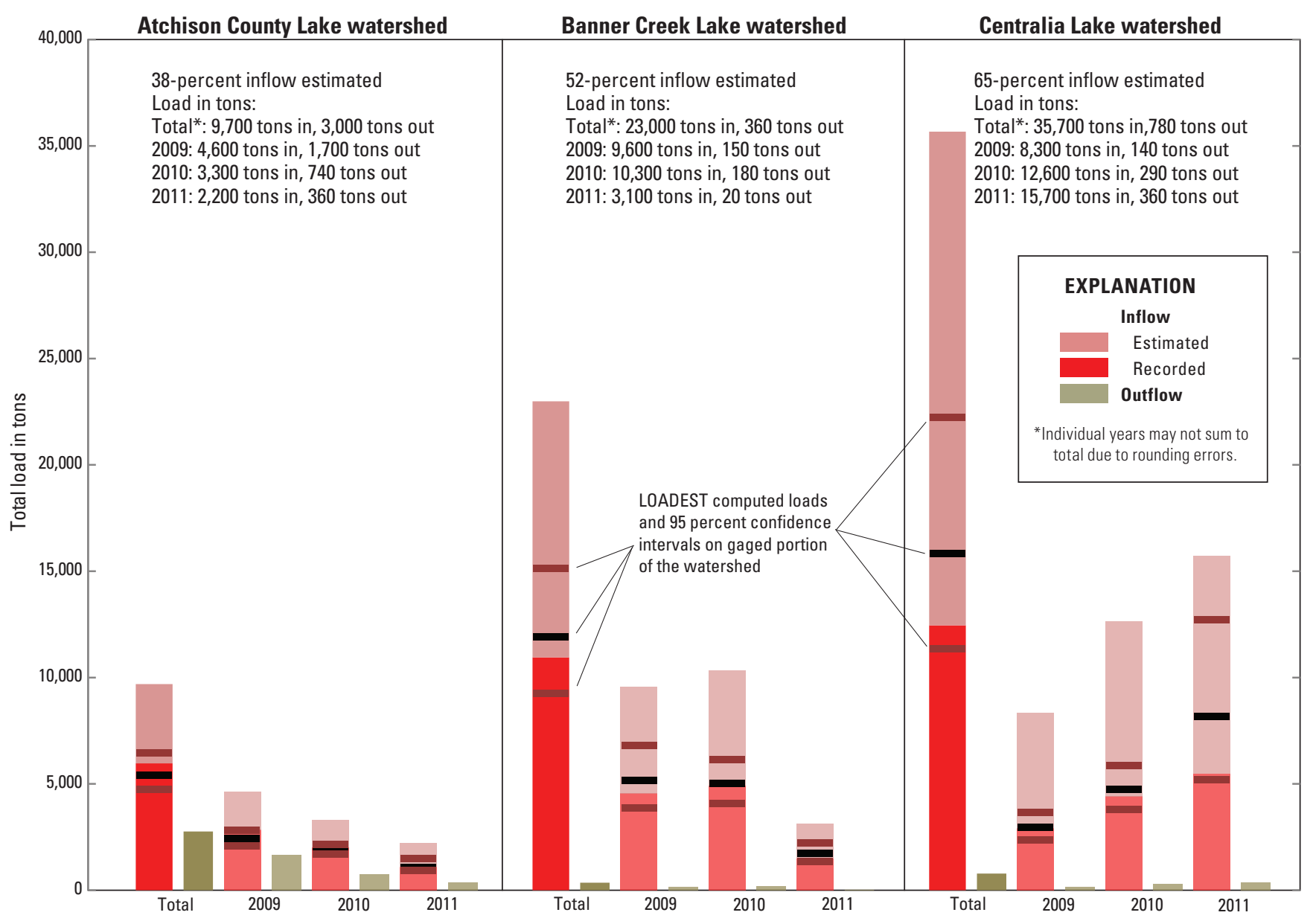

Figure 12. Computed and estimated sediment transport into and from each lake for study period during March 2009 through September 2011.

\section{Sediment Yields}

Total sediment yield at the upstream gage at Centralia $\left(2,800\right.$ tons per square mile (tons $\left.\left./ \mathrm{mi}^{2}\right)\right)$ was about 2.7 times that computed at the Atchison $\left(1,100\right.$ tons $\left./ \mathrm{mi}^{2}\right)$ and Banner upstream gages $\left(1,200\right.$ tons $\left./ \mathrm{mi}^{2}\right)$ during the study period (fig. 15). Computed mean annual sediment yields (360 tons $/ \mathrm{mi}^{2} / \mathrm{yr}$ at Atchison, 400 tons $/ \mathrm{mi}^{2} / \mathrm{yr}$ at Banner, and 970 tons $/ \mathrm{mi}^{2} / \mathrm{yr}$ at Centralia) were less at all three watersheds than those estimated by Collins (1965), who estimated between 2,000 and 5,000 tons $/ \mathrm{mi}^{2} / \mathrm{yr}$ for this area of Kansas. The difference between the results in this study and those of Collins are likely a combination of the use of more accurate techniques in this study and the difference in scale between the studies, Collins examined and averaged much larger regions while this study examined small headwater watersheds. Streamflow yield did not vary substantially between the three watersheds during the same period (fig. 15), with the largest total streamflow yield computed at Atchison, 1,700 acre feet per square mile (acre-ft/mi ${ }^{2}$ ), which equals a depth of runoff of $31.1 \mathrm{in.}$ Although more water was transported per unit area at Atchison, which has similar land use to Centralia, less sediment was transported (per unit area) from Atchison than Centralia. Atchison yields were similar to Banner, which represented the reference grassland condition for the purposes of this study (Kansas Water Office, 2009). LOADEST was used to compute sediment transport and 95-percent confidence intervals, which are included on figure 15. The LOADEST sediment transport estimates indicate that suspended-sediment yields at Centralia are significantly larger (at 95 percent confidence) than the other two watersheds. Despite an incomplete understanding of all the factors affecting sediment yields in Atchison (no complete survey of tile drains, riparian areas, and channelization), these results indicated that a cultivated watershed can carry yields similar to those observed under the assumed reference (or natural) condition.

Sediment transport at Banner may not represent a true reference condition if the streams were still adjusting to best management practices implemented from 1997 through 2007. These practices included 36 acres of agricultural land restored 


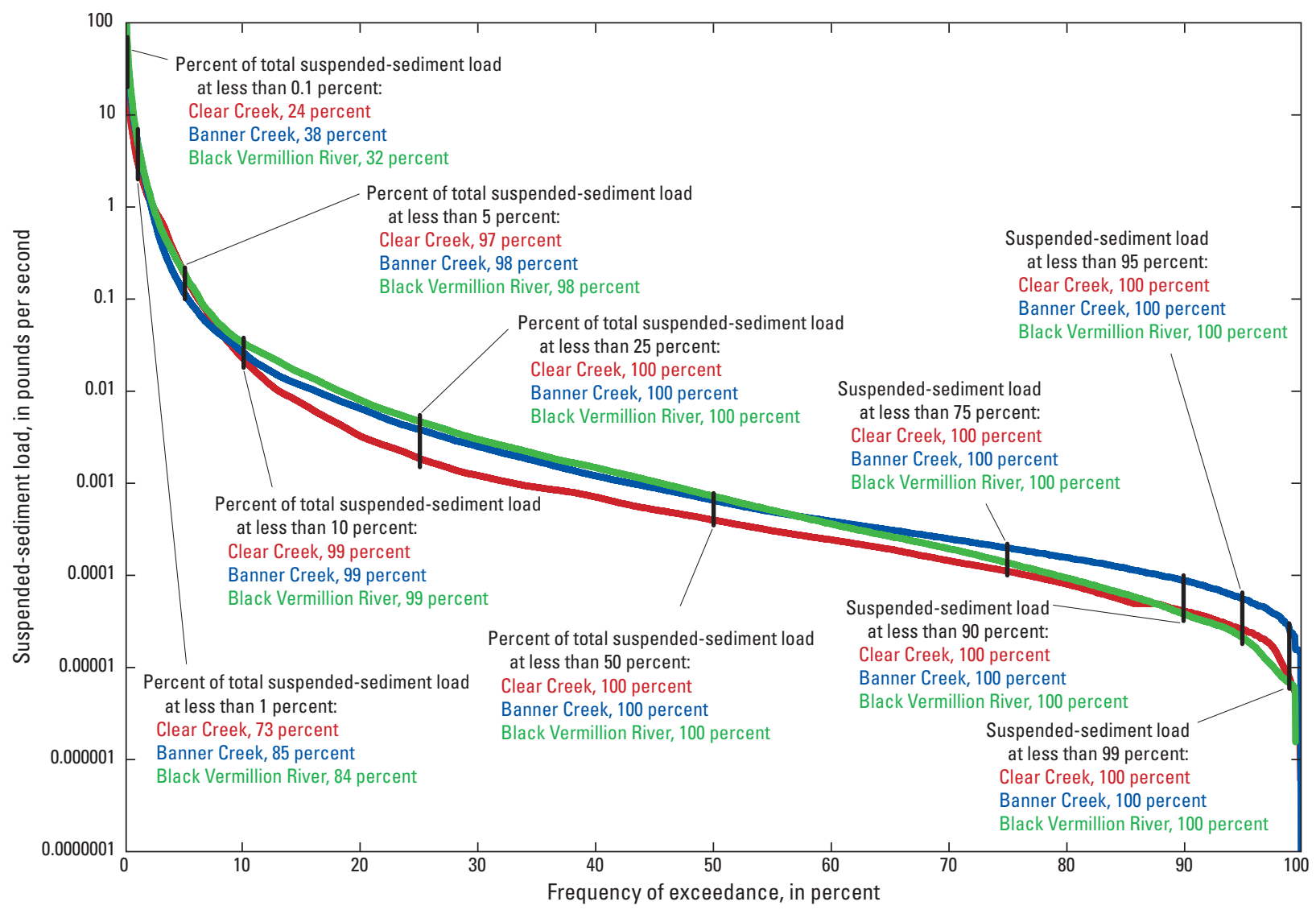

\section{EXPLANATION}

Suspended-sediment load duration curve, by stream

Clear Creek at Decatur Rd. (above Atchison County Lake)

Banner Creek at M Rd. (above Banner Creek Lake)

Black Vermillion River (above Centralia Lake)

Figure 13. Suspended-sediment load duration curves for study sites upstream from lakes during March 2009 through September 2011.

to native grass, an unspecified number of acres of brome grassland reseeded, and a reduction in the number of cattle crossings (U.S. Environmental Protection Agency, 2009). All of these practices may decrease sediment yields; however, not enough data were collected during this or previous studies to confirm this. Streambank sediment erosion was determined to be the highest at Banner ( 0.45 tons/foot/year) by a 2010 survey led by The Watershed Institute (TWI) as compared to Atchison (0.26 tons/foot/year) and Centralia (0.05 tons/foot/year) (The Watershed Institute and Gulf South Research Corporation, 2010). This streambank sediment erosion could be a factor in each watershed, under base-flow conditions, with Banner Creek having higher erosion and greater baseflow, resulting in greater low streamflow transport and causing an increase in subsequent estimated yields. Additionally, Juracek and Ziegler (2007) determined that channel-bank sources were the largest source of sediment to Banner Lake based on analysis of cesium-137 determined in sediment cores taken in the lake. Based on the high rates of erosion observed by TWI, and the corresponding information from Juracek, sediments in Banner Creek likely have a substantial streambank source.

Sediment loads extrapolated from streambank surveys varied widely in comparison to sediment loads computed at downstream USGS monitoring sites. Average streambank sediment erosion estimates computed by TWI (2010) were multiplied by the length of the main stem above the three upstream sampling sites, and then multiplied by the 3 years of the study. Because precipitation conditions during the period of study represent average conditions (fig. 9) mean annual estimates of streambank erosion should approximate conditions observed during the study period. Streambank contributions from the main stem of Banner Creek are three 

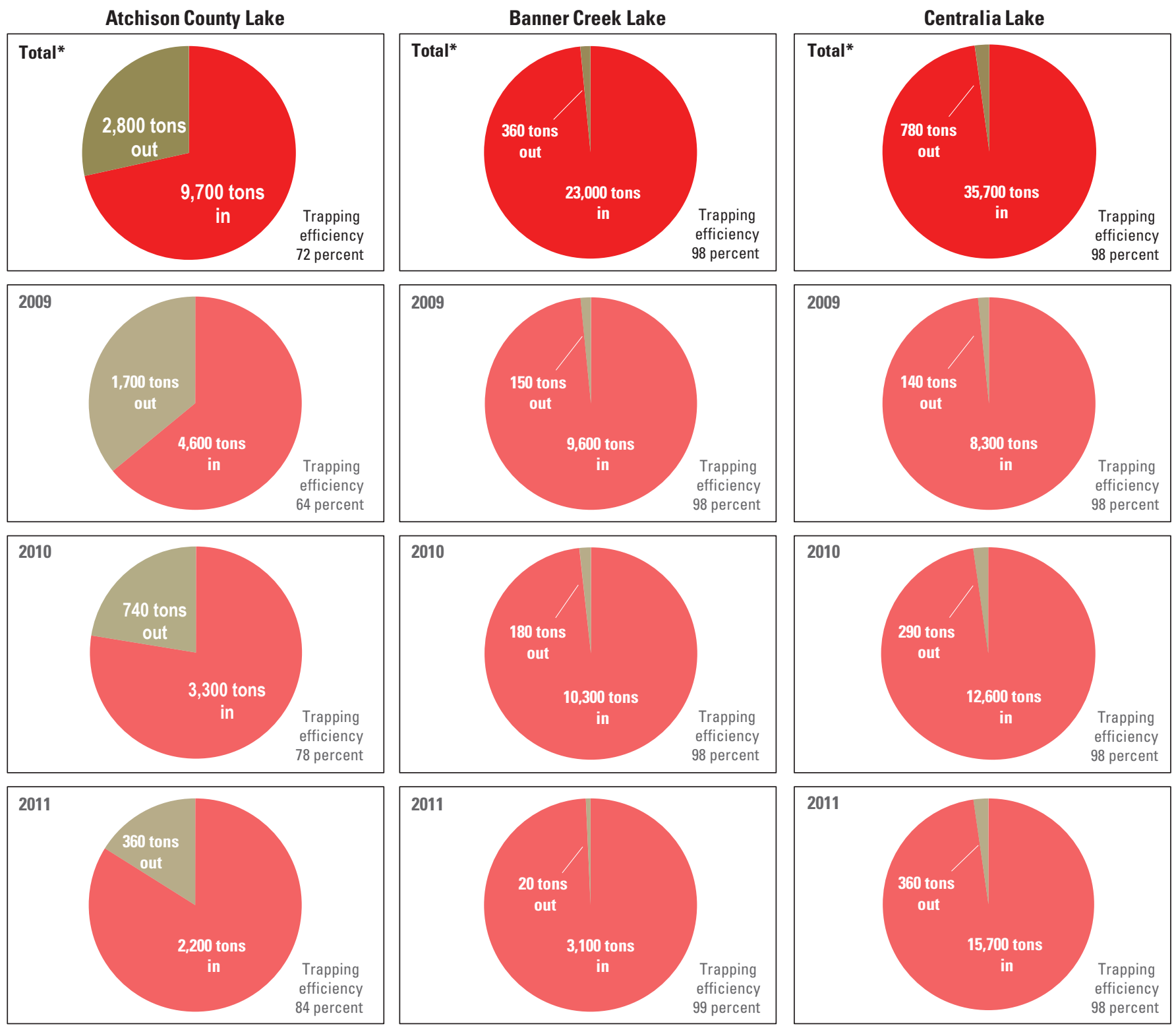

* Individual years may not sum to total due to rounding errors

Figure 14. Total and mean annual trapping efficiencies and loads into and from each study lake during March 2009 through September 2011.

times more than the sediment load observed at Banner Creek at M. Rd., 2.6 times more than the sediment load observed at Clear Creek at Decator Rd. (upstream from Atchison County Lake), and are 22 percent of the load computed at the Black Vermillion River above Centralia Lake. Substantially larger estimates of sediment contributions from only a portion of the streams in the Banner and Atchison County watersheds indicate that the extrapolation of average streambank-erosion rates from discrete, nonrandomized surveys can misrepresent the relative importance of streambanks when compiling sediment budgets. These survey-based estimations directly contradict the results found by the continuous monitoring and regression model methods used for this study, and indicate the best quantification methods are needed to determine the effectiveness of best management practices.

The larger sediment yield in 2011 at the Centralia Lake watershed, a year with lower precipitation, can be explained by a large storm that transported 890 tons $/ \mathrm{mi}^{2}$ during a 27 -day period. This large storm occurred while fields were observed to be recently plowed throughout the watershed, which would have exposed and loosened field topsoils. Despite less streamflow in 2011, greater sediment loads indicate that not all storm events transport the same amount of sediment; larger, extreme storms during the spring may transport much larger sediment loads in small Kansas watersheds. Seasonal comparisons between fall and spring are problematic because 


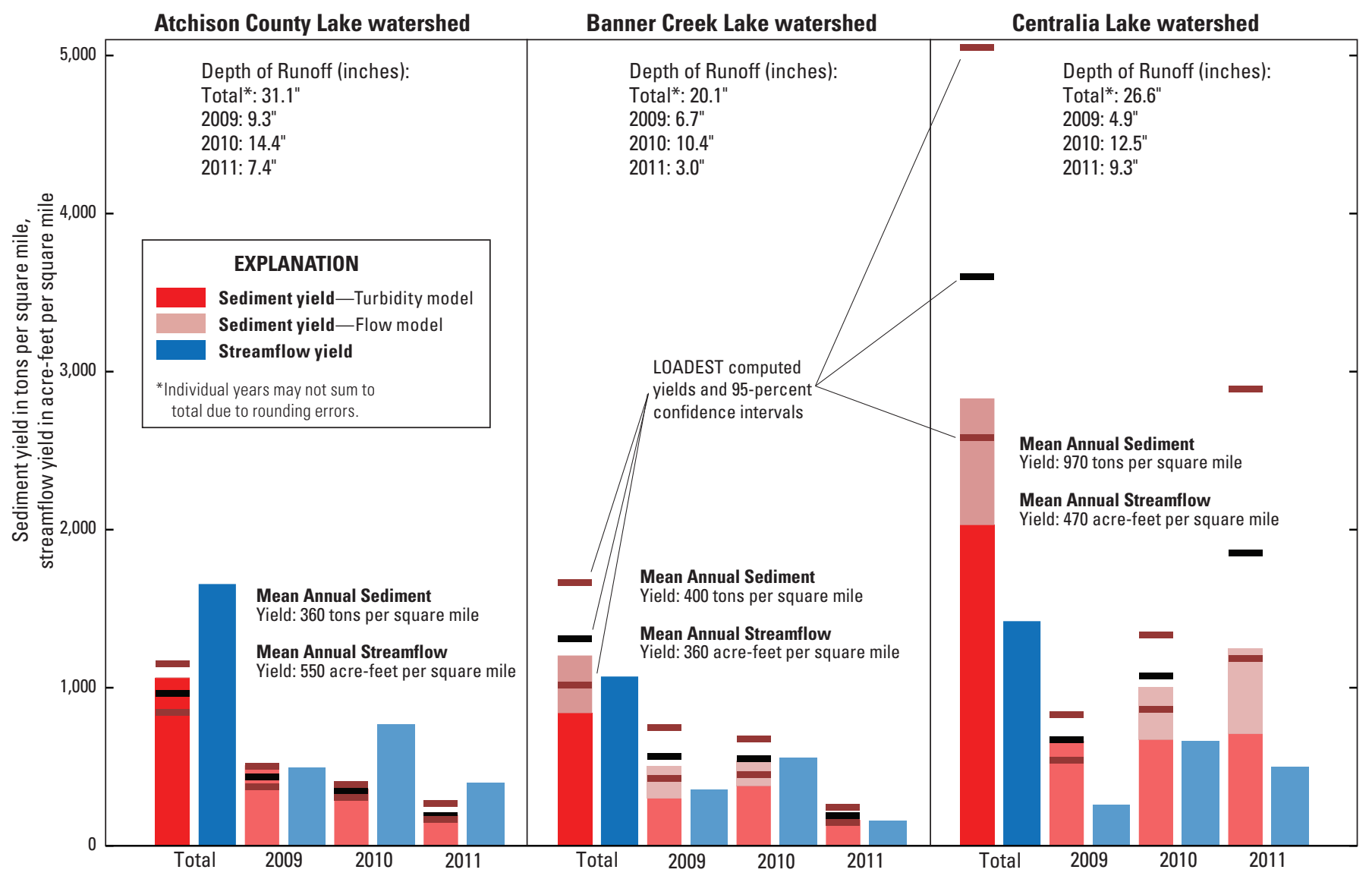

Figure 15. Total and mean annual sediment yield and streamflow and corresponding depth of runoff for study period during March 2009 through September 2011.

of the dry fall seasons observed during the study period; however, mean sediment yields and mean runoff depths during spring were 200 tons $/ \mathrm{mi}^{2}$ (4.8 in. runoff depth) at Atchison, 260 tons $/ \mathrm{mi}^{2}$ (3.7 in. runoff depth) at Banner, and 560 tons $/ \mathrm{mi}^{2}$ (5.4 in. runoff depth) at Centralia, whereas mean fall sediment yields were 46 tons $/ \mathrm{mi}^{2}$ (1.7 in. runoff depth) at Atchison, 2 tons $/ \mathrm{mi}^{2}$ (0.5 in. runoff depth) at Banner, and 10 tons $/ \mathrm{mi}^{2}$ (0.5 in. runoff depth) at Centralia. These estimates do indicate greater yields during spring, which typically has greater precipitation and cultivation, as opposed to the post-harvest fall season, which has less rainfall and field topsoil that could be protected by leaf litter or are more compacted and less easily transported.

Stream channels in Centralia have been straightened (The Watershed Institute and Gulf South Research Corporation, 2010), which causes incision and increased transport because of channel adjustment resulting from increased stream velocities. Atchison County Lake and Banner Creek Lake watersheds had some vegetated riparian buffer along upstream banks (The Watershed Institute and Gulf South Research Corporation, 2010) which may increase the stability of streambanks, potentially decreasing downstream sediment transport (Sheridan and others, 1999, Zaimes and others, 2004). The presence of more tile drains in Atchison as compared to Centralia, 41 and 22 percent, respectively (table 2), may decrease sediment yields, because tile drains have been indicated to decrease sediment erosion from fields (Istok \& Kling, 1983; Food and Agricultural Policy Research Institute, 2008). The difference in sediment yield between the Centralia Lake watershed and the other two study watersheds could also be related to increased channel adjustment, fewer riparian buffers, increased agricultural land use, and fewer upstream sub-impoundments relative to Banner Creek Lake watershed, and the potential for increased channel adjustment, fewer small upstream sub-impoundments, less tile drains, and less vegetated riparian buffers on upstream tributaries relative to Atchison County lake watershed (fig. 2; table 2). To quantify the effects of ponds on watershed sediment yields, streamflow and sediment transport were computed at two small NID listed ponds in the Atchison watershed during April through August 2011. 


\section{Effect of Ponds on Total Watershed Sediment} Yield

\section{Storms}

Five storms occurred during the study period, which resulted in flow through the Atchison ponds. Rainfall depths for each storm were recorded at the NWS weather station at Horton, Kansas (table 8). For both ponds, outflow volumes were less than inflow volumes for all of these storms because some of the inflow remained stored in the ponds.

\section{Little Delaware Mission Dam 5}

Stormflow, sediment transport, yields, and trapping efficiency for LDMD 5 are indicated in table 8. Graphs of estimated discharge and SSC are indicated in figures 16A-E. Computed inflow discharges ranged from 18 to $99 \mathrm{ft}^{3} / \mathrm{s}$, and storm loads ("load in" on table 8) ranged from 0.5 to 9.7 tons.
Trapping efficiencies, by storm, ranged from 68 percent during storm 1 to -0.1 percent (the negative implying resuspension of previously deposited sediment, as a result of the age of the ponds indicating they are mostly silted in) estimated during storm 3. Average trapping efficiency during the five observed storms was 23 percent.

\section{Little Delaware Mission Dam 17}

Stormflow, loads, yields, and trapping efficiency for LDMD 17 are indicated in table 8. Graphs of estimated discharge and SSC are indicated in figures $16 \mathrm{~F}-\mathrm{J}$. Computed inflow discharges ranged from 33 to $148 \mathrm{ft}^{3} / \mathrm{s}$, and storm loads ("load in" on table 8) ranged from 6.5 to 43 tons. Trapping efficiencies, by storm, ranged from 69 percent during storm 1 to -24 percent (the negative implying resuspension of previously deposited sediment, as a result of the age of the ponds indicating they are mostly silted in) estimated during storm 5. Average trapping efficiency during the five observed storms was 30 percent.

Table 8. Stormflows, sediment transport, trapping efficiencies, and sediment yields for study ponds Little Delaware Mission Dam (LDMD) 5 and LDMD 17 (rainfall totals recorded by National Weather Service Weather Station at Horton, Kansas) from April through August 2011.

[LDMD, Little Delaware Mission Dam; $\mathrm{ft}^{3} / \mathrm{s}$, cubic foot per second; $\mathrm{AF}$, acre-feet; \%, percentage; tons $/ \mathrm{mi}^{2}$, ton per square mile]

\begin{tabular}{|c|c|c|c|c|c|c|c|c|c|}
\hline \multirow[b]{2}{*}{ Storm } & \multirow[b]{2}{*}{ Dates } & \multirow[b]{2}{*}{$\begin{array}{l}\text { Precipitation } \\
\text { (inches) }\end{array}$} & \multicolumn{7}{|c|}{ LDMD 5} \\
\hline & & & $\begin{array}{l}\text { Peak inflow } \\
\left(\mathrm{ft}^{3} / \mathrm{s}\right)\end{array}$ & $\begin{array}{c}\text { Flow IN } \\
\text { (AF) }\end{array}$ & $\begin{array}{l}\text { Flow OUT } \\
\text { (AF) }\end{array}$ & $\begin{array}{c}\text { Load IN } \\
\text { (tons) }\end{array}$ & $\begin{array}{l}\text { Load OUT } \\
\text { (tons) }\end{array}$ & $\begin{array}{c}\text { Trapping } \\
\text { efficiency } \\
(\%)\end{array}$ & $\begin{array}{c}\text { Sediment } \\
\text { yield } \\
\text { (tons/mi) }\end{array}$ \\
\hline 1 & May 25 to May 26 & 2.3 & 38 & 13 & 7.8 & 3.8 & 1.2 & 68 & 4.8 \\
\hline 2 & May 31 to June 6 & 2.5 & 59 & 37 & 27 & 9.7 & 6.1 & 37 & 12 \\
\hline 3 & June 25 to June 29 & 2.5 & 84 & 42 & 32 & 8.5 & 8.6 & -0.1 & 11 \\
\hline \multirow[t]{2}{*}{5} & July 7 to July 9 & 2.0 & 99 & 39 & 32 & 7.8 & 7.2 & 8 & 10 \\
\hline & & & Totals & $139^{*}$ & $101^{*}$ & $30^{*}$ & $23^{*}$ & $\begin{array}{c}23^{*} \\
\text { Average }\end{array}$ & $39^{*}$ \\
\hline
\end{tabular}

\begin{tabular}{|c|c|c|c|c|c|c|c|c|}
\hline \multirow[b]{2}{*}{ Storm } & \multirow[b]{2}{*}{ Dates } & \multicolumn{7}{|c|}{ LDMD 17} \\
\hline & & $\begin{array}{c}\text { Peak inflow } \\
\left(\mathrm{ft}^{3} / \mathrm{s}\right)\end{array}$ & $\begin{array}{c}\text { Flow IN } \\
\text { (AF) }\end{array}$ & $\begin{array}{l}\text { Flow OUT } \\
\text { (AF) }\end{array}$ & $\begin{array}{c}\text { Load IN } \\
\text { (tons) }\end{array}$ & $\begin{array}{l}\text { Load OUT } \\
\text { (tons) }\end{array}$ & $\begin{array}{c}\text { Trapping } \\
\text { efficiency } \\
(\%)\end{array}$ & $\begin{array}{c}\text { Sediment } \\
\text { yield } \\
\left(\text { tons } / \mathrm{mi}^{2}\right)\end{array}$ \\
\hline 1 & May 25 to May 26 & 39 & 28 & 16 & 12 & 3.6 & 69 & 15 \\
\hline 2 & May 31 to June 6 & 53 & 36 & 34 & 18 & 9.2 & 49 & 23 \\
\hline 3 & June 25 to June 29 & 85 & 51 & 47 & 43 & 25 & 42 & 56 \\
\hline \multirow[t]{3}{*}{5} & July 7 to July 9 & 148 & 57 & 56 & 24 & 30 & -24 & 31 \\
\hline & & Totals & $182^{*}$ & $161^{*}$ & $103^{*}$ & $72^{*}$ & $30^{*}$ & $134^{*}$ \\
\hline & & & & & & & Average & \\
\hline
\end{tabular}

\footnotetext{
*Sum of individual columns might not match total due to rounding errors.
} 
A. LDMD 5 storm 1

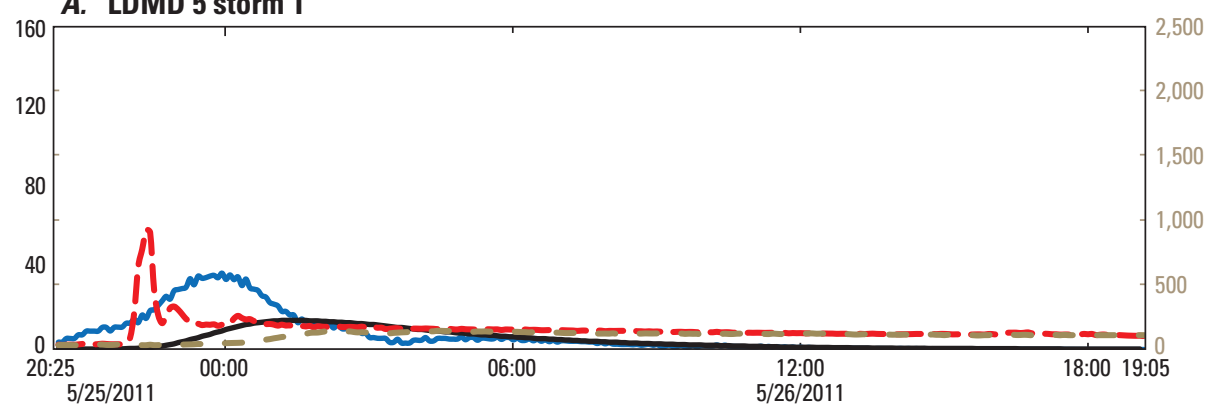

B. LDMD 5 storm 2

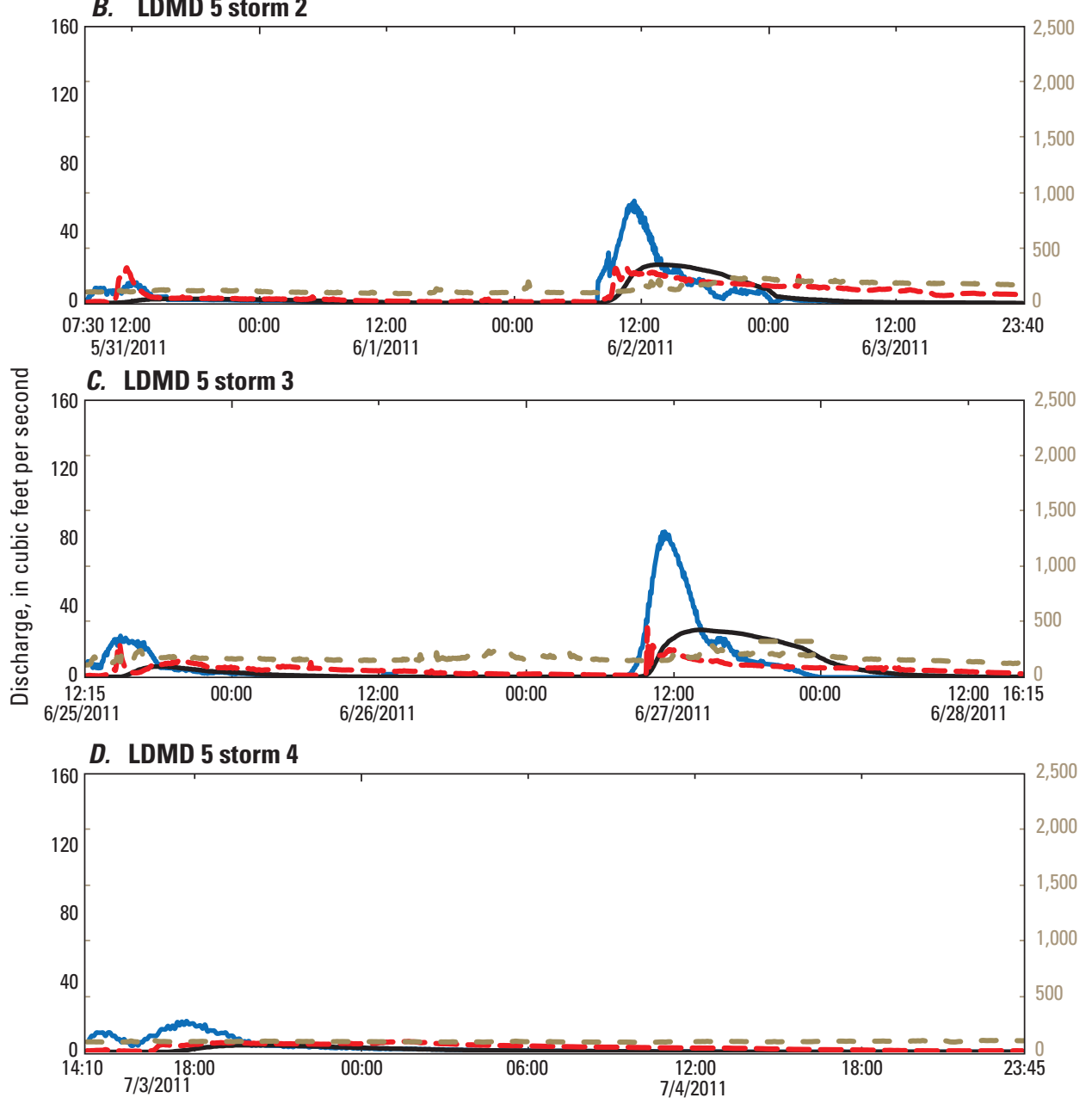

E. LDMD 5 storm 5

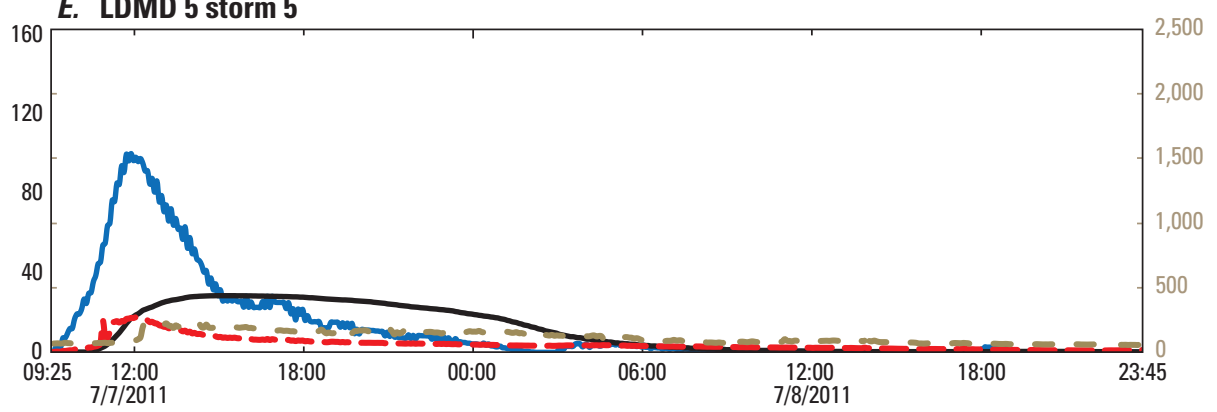

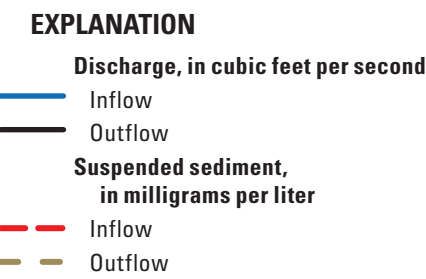

LDMD, Little Delaware Mission Dam

Figure 16. Stormflow and suspended-sediment concentration hydrographs for Little Delaware Mission Dam (LDMD) 5 (A-E) and LDMD 17 (F-J) for each storm (rainfall totals recorded by National Weather Service (NWS) Weather Station at Horton, Kansas), April through August 2011. 
F. LDMD 17 storm 1

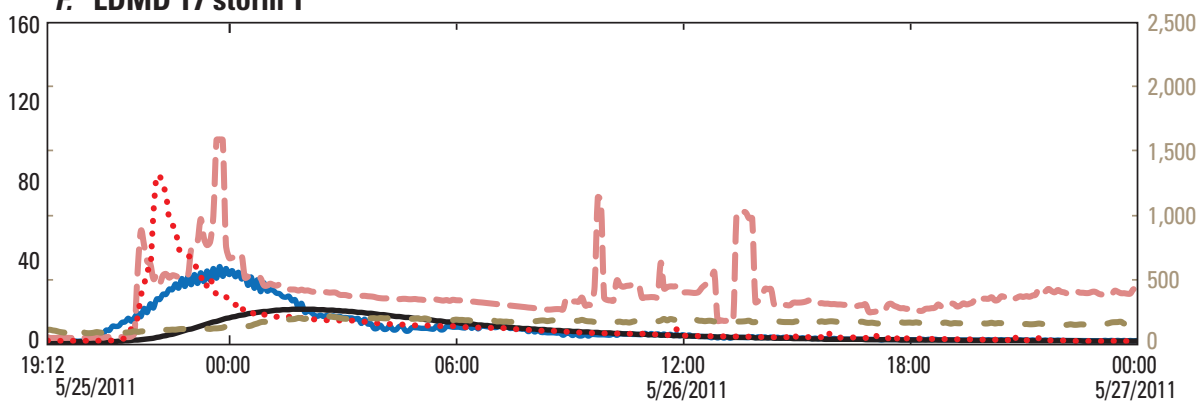

G. LDMD 17 storm 2

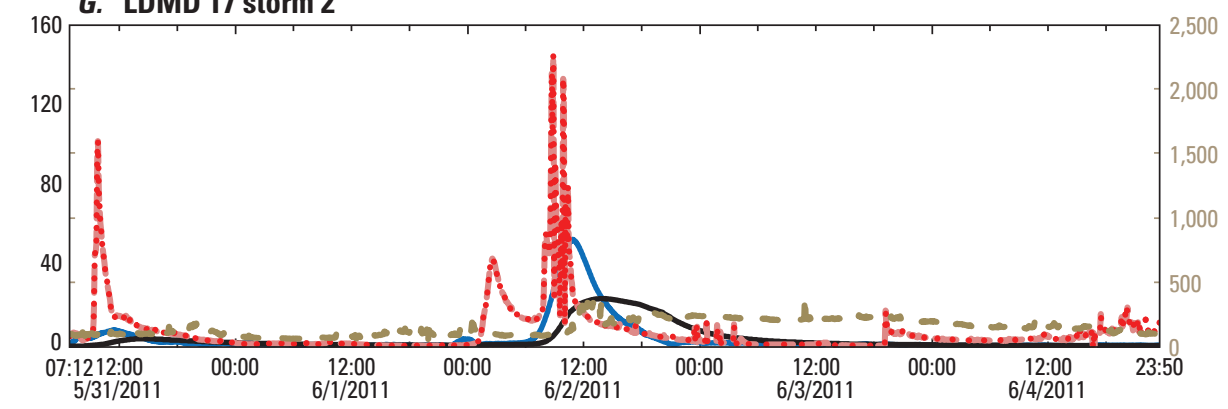

든 H. LDMD 17 storm 3

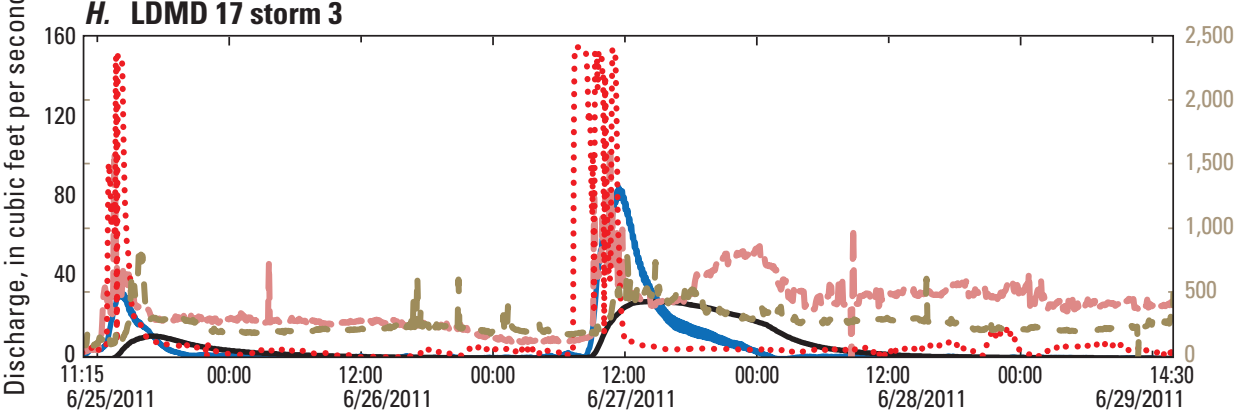

1. LDMD 17 storm 4
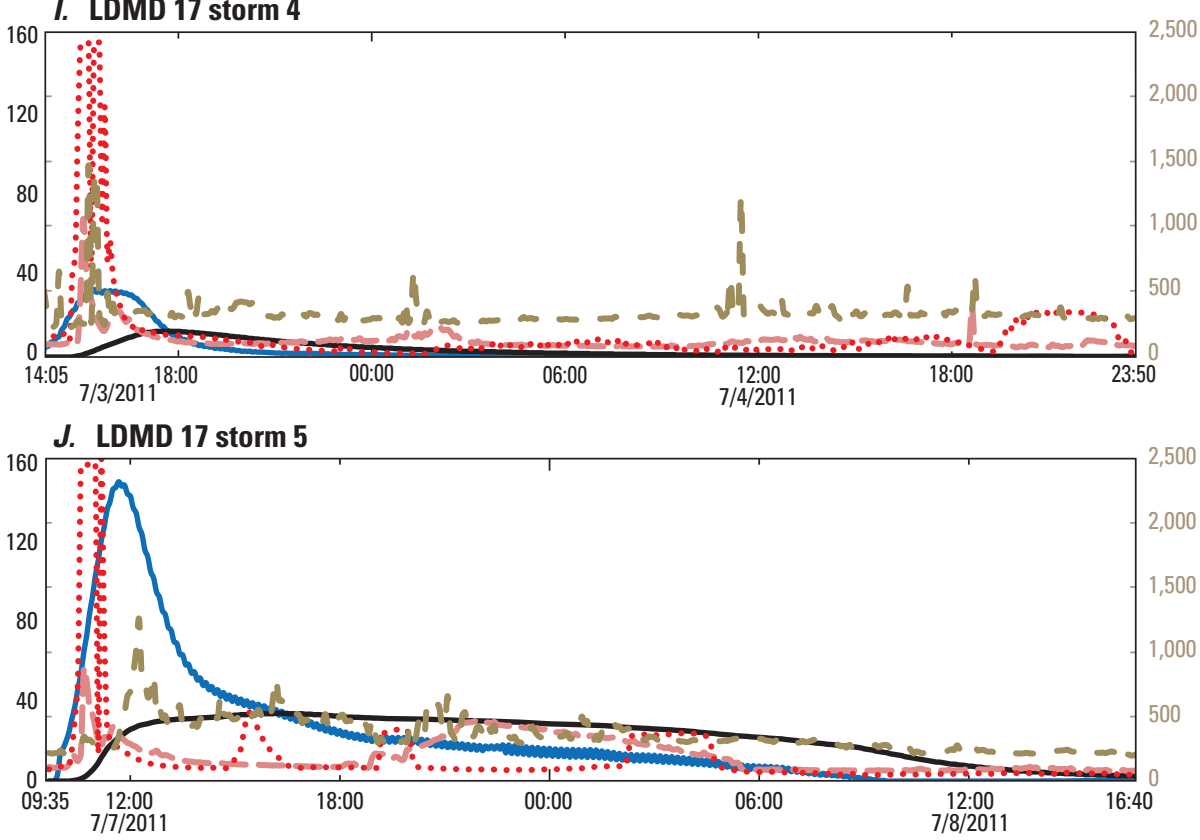

\section{EXPLANATION}

Discharge, in cubic feet per second

Inflow

- Outflow

Suspended sediment, in milligrams per liter

- North inflow

..... South inflow

- Outflow

LDMD, Little Delaware Mission Dam

Figure 16. Stormflow and suspended-sediment concentration hydrographs for Little Delaware Mission Dam (LDMD) 5 (A-E) and LDMD 17 (F-J) for each storm (rainfall totals recorded by National Weather Service (NWS) Weather Station at Horton, Kansas), April through August 2011.-Continued 


\section{Comparison of Results Between Ponds}

Inflow SSC was larger at LDMD 17 than those at LDMD 5 (fig. 16). Initial storm sediment loads were typically high, and were followed by a more gradual increase in sediment outflows (fig. 16). Sediment inflows at LDMD 5 were much less than at LDMD 17 and subsequent sediment outflows were steady during the period of the storm (fig. 16). Sediment transport at LDMD 17 experienced more fluctuation (table 8) leaving the pond, and similar to much higher sediment loading into that site. Given similar channel slopes, land use, and management practices in both ponds, the presence of an established grass buffer at LDMD 5 may be the most important factor contributing to smaller sediment loads entering the pond.

Two factors may influence variation in sediment trapping among the 5 storms observed at LDMD 5 and 17. First, sediment trapping generally decreased through time at both sites, possibly indicating that sediments stayed suspended after storms only to be flushed out by subsequent storms. Second, sediment trapping efficiencies are smallest during the highest flow events, implying that sediments are transported through, or resuspended from these ponds. This second factor implies that during the largest storms (which previously were shown to transport the majority of sediments at primary study sites) small farm ponds may not serve as sinks for sediments transported from upstream fields.

Trapping efficiency decreased to a net loss of sediment at LDMD 17 over each individual storm event, the average trapping efficiency over all five storm events was 30 percent. Loss of trapping efficiency is expected as pond volume decreases due to sediment deposition; however, causes for this decrease were not readily apparent in the streamflow or turbidity data. Steady SSC at the outflow during storms (fig. 16), after the initial sediment inflow passed through, can be explained by resuspended sediment or algae growth, data errors, or some combination of these factors. One possible cause of the trapping efficiency decrease is that sediment flushed into the ponds from earlier storms stayed suspended, allowing it to be flushed with the initial inflow of the next storms flow. Short intervals occurred between storms 1 and 2, and storms 4 and 5 , and trapping efficiency decreases between these two events dropped considerably (table 8).

Because this study only spanned 4 months and five storms, these results could indicate that during periods with low flows, such as winter, sediments may fall out or become compacted, and are thus less likely to stay suspended or be resuspended by subsequent flows. During periods when storm events are more closely spaced, trapping efficiency becomes less changed to almost unchanged. Because most of the suspended load was composed of silts and clays (94 percent average less than 63 micrometers, table 7), long suspension times can be expected. By Stokes law (Daugherty and Ingersoll, 1954), a computation of the settling rates of silts and clays range from $9.02 \times 10^{-3}$ to $2.62 \times 10^{-4}$ feet per second. Days of moderate to high winds would assist in maintaining suspension, and may cause resuspension of previously deposited sediments. The relatively short interval between the final two storms was likely a factor in the flushing of previously suspended sediments. In addition, negative and small sediment trapping efficiencies were estimated in each pond during storm 5, the largest storm in terms of peak and total flow at both sites. High flows may resuspend previously deposited sediments, and thus trapping efficiency of ponds of this age may remain unchanged (or even contribute sediments to downstream loads) during large storms.

\section{Comparison of Pond Results to Flow and Loads at Clear Creek at Decatur Rd. (upstream from Atchison County Lake)}

Although the studied farm ponds comprised 22 percent of the drainage upstream from the Clear Creek (upstream from Atchison County Lake) site, flow from these ponds during

Table 9. Comparison of sediment loads between small study ponds Little Delaware Mission Dam (LDMD) 5 and LDMD 17, and Clear Creek at Decator Rd. (upstream from Atchison County Lake) during April through August 2011.

\begin{tabular}{ccccc}
\hline & $\begin{array}{c}\text { Load observed entering } \\
\text { ponds } \\
\text { (tons) }\end{array}$ & $\begin{array}{c}\text { Load trapped in study } \\
\text { ponds } \\
\text { (tons) }\end{array}$ & $\begin{array}{c}\text { Load passing Clear Creek } \\
\text { gage } \\
\text { (tons) }\end{array}$ & $\begin{array}{c}\text { Percent of total load trapped } \\
\text { (tons) }\end{array}$ \\
\hline Storm 1 & 16 & 11 & 73 & 12 \\
Storm 2 & 28 & 13 & 104 & 10 \\
Storm 3 & 51 & 18 & 125 & 10 \\
Storm 4 & 7.0 & 2.5 & 8.9 & 16 \\
Storm 5 & 32 & -5.3 & 105 & -4 \\
\hline \multicolumn{1}{c}{ Totals } & $134^{*}$ & $38^{*}$ & $416^{*}$ & $8^{*}$ \\
& & & & Percent of total load (trapped/ \\
& & & & (load entered+load passed) \\
\hline
\end{tabular}

*Sum of individual columns might not match total due to rounding errors. 


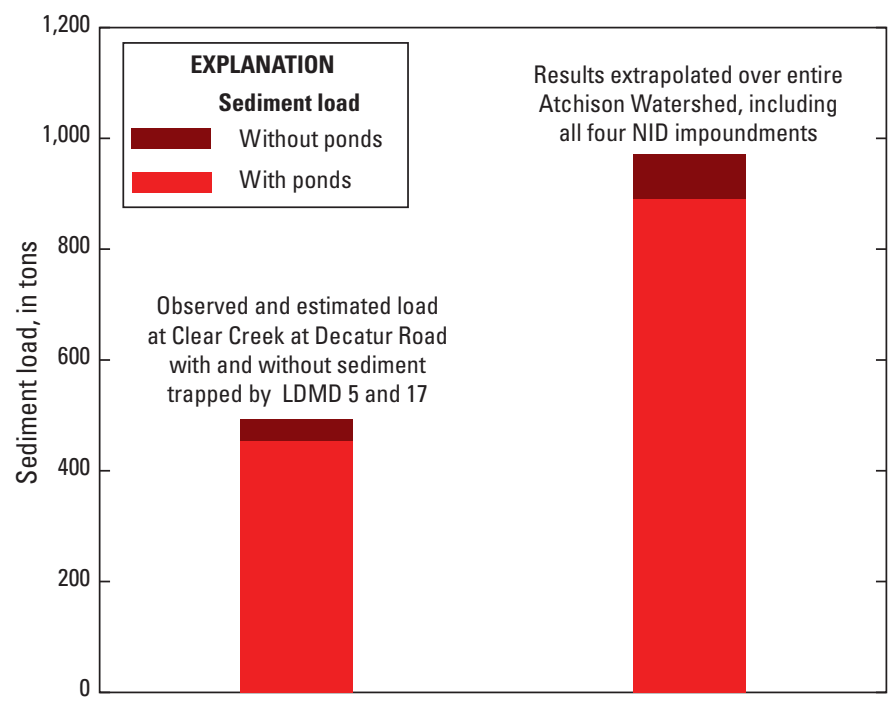

Figure 17. Difference in sediment loads with and without the two small study ponds on total watershed sediment transport (during the five observed storms), and extrapolated during entire watershed and all four National Inventory of Dams listed ponds during April through August 2011.

the 5 storms comprised 28 percent of the flow observed at the Clear Creek (upstream from Atchison County Lake) site. Increased downstream flows may be because of uneven distribution of rainfall, agricultural diversions, tile drains draining groundwater, or stream losses to groundwater.

For these five storm events, a total of 416 tons of sediment passed by the Clear Creek streamgage at Decatur Rd. (upstream from Atchison County Lake) (table 9). It is estimated that 38 tons of sediment were trapped in the two study ponds during the study period, amounting to 8 percent of the load upstream from the Clear Creek at Decatur Rd. (upstream from Atchison County Lake) gage during the five observed storm events. Sediment inflow during periods when the pond elevation was below the outflow structure was not estimated, and would increase the amount of sediment trapped (assuming all inflows carry some sediment). There are two more NID listed ponds in the Atchison watershed, and numerous non-listed smaller ponds likely trap sediment in the same manner as LDMD 5 and LDMD 17. By extrapolating these results to the other two NID listed impoundments in the Atchison watershed, which drain 26 percent of the watershed, about 9 percent of total watershed sediment loads (including the ungaged drainage area) could be retained by these impoundments (fig. 17). These results do not explain the large difference in yields between Atchison County Lake watershed and Centralia Lake watershed, implying that differences in factors, such as riparian buffers, stream channelization, or the extent of tile drains, may better explain differences in sediment loading.

\section{Comparison of Sediment Loads and Yields to other Watersheds in Northeast Kansas}

\section{Comparison to Mill Creek Watershed, Johnson County, Kansas}

Lee and Ziegler (2010a) characterized sediment transport from basins in the urban and urbanizing Mill Creek watershed in Johnson County, Kansas, from February 2006 through November 2008. Monitoring sites drained basins of similar size to headwater basins in this report, and streamflow and turbidity data were collected using similar methods. Land use in the watersheds in the Lee and Ziegler (2010a) study included urban watersheds with large percentages of impervious surface as well as or urbanizing watersheds with extensive construction and therefore, was much different than the watersheds described in this report. Urbanizing watersheds can have one hundred times the sediment loads of agricultural or undeveloped watersheds (Walling and Gregory, 1970). Although the Mill Creek sites were different in terms of location and precipitation conditions, insights into the relative role of agricultural land use compared with urban land use can be gained through comparison of similarly sized basins with similar silt and clay soils.

Streamflow yields were larger throughout all Mill Creek sub-watersheds as compared with this study's baseline watersheds and are attributed to larger rainfall during the study period and more impervious surfaces resulting in larger volumes of surface and shallow sub-surface flow during storm events (fig. 18). Sediment yields from the urbanizing Clear Creek at Clare Rd. site [390051094522200, not to be confused with the Clear Creek at Decatur Rd. site (upstream from Atchison County Lake)] were only slightly larger than those from the Black Vermillion River above Centralia Lake in the agricultural Centralia watershed, despite increased flow (fig. 18). This comparison indicates that at the small $\left(5-10 \mathrm{mi}^{2}\right)$ watershed scales, small, primarily agricultural basins have the potential to export sediment at levels comparable to small urbanizing watersheds.

Sites downstream from established urban areas (385952094454000 Little Mill Creek at Lackman Rd. and 385404094485800 Mill Creek at Woodland Rd.) had similar sediment yields in comparison to Clear Creek at Decatur Rd. (upstream from Atchison County Lake) and Banner Creek at M Rd. (Banner) (fig. 18) despite increased flow. Given that Banner represents "reference" grassland conditions, results indicate that among small, 5-10 $\mathrm{mi}^{2}$ basins, sediment yields from stable urban areas can be similar to primarily grassland conditions. 


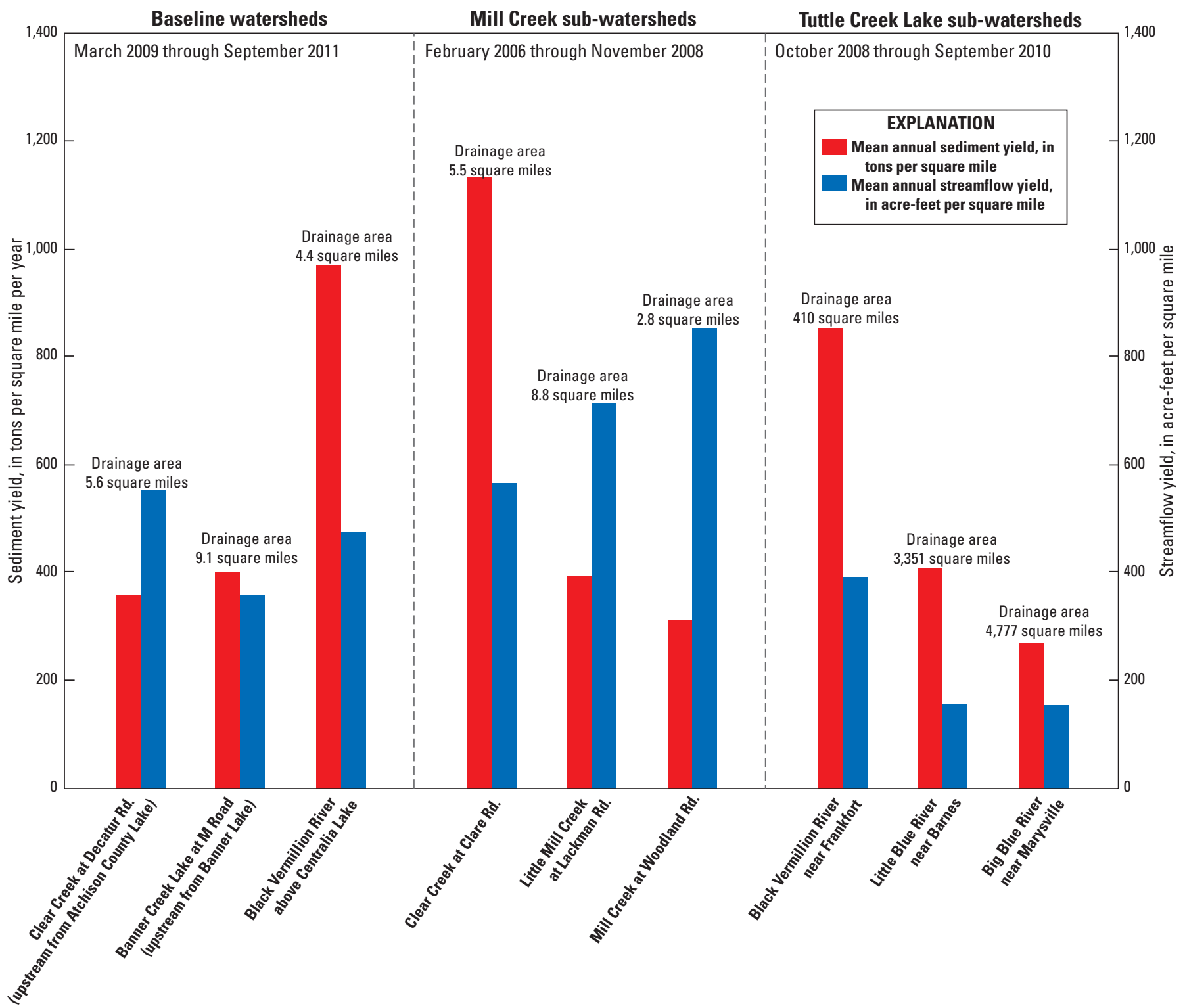

Figure 18. Comparison of mean annual sediment yield and streamflow yield with study watersheds and sub-watersheds in the Mill Creek Watershed, Johnson County, Kansas, and the Tuttle Creek lake watershed (Lee and others, 2010b; Juracek, 2011).

\section{Comparison to Tuttle Creek Impoundment Watershed}

Juracek (2011) monitored three sites within the Tuttle Creek Lake watershed from October 2008 through September 2010 for streamflow and suspended-sediment using similar methods to those described in this report. The Centralia watershed is a headwater watershed that drains into the Tuttle Creek Lake watershed (fig. 1). The Tuttle Creek Lake watershed drains an area of 9,628 $\mathrm{mi}^{2}$ and encompasses parts of southeast Nebraska and northeast Kansas. The three monitored sites were 06882510 Big Blue River at Marysville, Kansas, which drains 4,777 $\mathrm{mi}^{2}$; 06884400 Little Blue River near Barnes, Kansas, which drains 3,351 $\mathrm{mi}^{2}$; and 06885500 Black Vermillion River near Frankfort, Kansas, which drains $410 \mathrm{mi}^{2}$, and is downstream and surrounds the Centralia watershed. The Tuttle Creek Lake watershed is 70 percent agricultural, 24 percent grassland, and the remainder woodland and urban (Juracek, 2011).

Mean annual suspended-sediment yield for the Black Vermillion River near Frankfort watershed was estimated to be $850 \mathrm{tons} / \mathrm{mi}^{2} / \mathrm{yr}$ (Juracek, 2011); smaller than the mean annual sediment yield for the Centralia watershed (970 tons $/ \mathrm{mi}^{2} / \mathrm{yr}$ ), but substantially larger than mean annual sediment yields at Clear Creek at Decatur Rd. (upstream from Atchison County Lake) (350 tons $/ \mathrm{mi}^{2} / \mathrm{yr}$ ) and Banner Creek 
at M Rd. (400 tons $/ \mathrm{mi}^{2} / \mathrm{yr}$; fig. 18). While sediment yields are thought to decrease from headwater to downstream sites because of decreasing channel slope and increased area for temporary storage and deposition of sediments (Schumm, 1977), sediment yields are much larger relative to other headwater sites, especially considering that 98 percent of the Centralia watershed's load is trapped within Centralia Lake. Larger yields in the Black Vermillion River watershed could be related to natural factors, such as soil type, channel slopes, and local geology, but without more information on reference yields, the degree of streambank erosion, or the extent of best management practices, it is difficult to ascertain the extent to which human actions or natural factors are causing increased sediment transport. The gaging sites at Barnes and Marysville had sediment yields of 410 and 270 tons per $\mathrm{mi}^{2}$, respectively, which, despite their vastly larger size, were similar to those yields estimated at Atchison and Banner (fig. 18). As with the Black Vermillion River watershed, more information is needed to determine why sediment yields in much larger basins are similar to those observed in small watersheds.

\section{Summary and Conclusions}

The U.S. Geological Survey, in cooperation with the Kansas Water Office, investigated sediment transport to and from three small impoundments in northeast Kansas from March 2009 through September 2011. Streamgages and turbidity sensors collected continuous 15-minute data upstream and downstream from Atchison County, Banner Creek, and Centralia Lakes in northeast Kansas. These sites were selected for study because they differed with respect to the extent or management of upstream agricultural activities. The Atchison County Lake and Centralia Lake watersheds have extensive agricultural activity, but both are similar with regard to installation of terraces and implementation of reduced and no tillage. However Atchison has more farms ponds, more tile drainage, and has more streams with riparian buffers. The Centralia Lake watershed is less tile drained, and streams are generally more channelized and have less riparian buffer. The Banner Creek Lake watershed is primarily grassland and pasture, has stream channels with riparian buffers, and has many farm ponds. Data from sampling sites were used to estimate sediment transport to and from each reservoir, and to characterize how natural factors and agricultural practices affect sediment transport in small watersheds in northeast Kansas.

The vast majority of sediment was transported to studied reservoirs during high flow conditions. Seventy-three to eighty-five percent of sediment loads were transported past headwater monitoring stations 1 percent of the time. Computed mean annual sediment yields (360 tons $/ \mathrm{mi}^{2} / \mathrm{yr}$ at Atchison, 400 tons $/ \mathrm{mi}^{2} / \mathrm{yr}$ at Banner, and 970 tons $/ \mathrm{mi}^{2} / \mathrm{yr}$ at Centralia) were less at all three watersheds than those estimated by Collins (1965), who estimated between 2,000 and 5,000 tons $/ \mathrm{mi}^{2} / \mathrm{yr}$ for this area of Kansas. Although small yields from Banner Creek were expected because of little agricultural activity, sediment yields at heavily cultivated Atchison County site were less than expected relative to Banner Creek or Centralia sites. These results also indicated that a cultivated watershed can carry yields similar to those observed under the assumed reference (or natural) condition. Data collected at two farm ponds upstream from Atchison County Lake in 2010 indicated average trapping efficiencies of 23 to 30 percent during five storms, but only 8 percent of the total load upstream from the Clear Creek at Decatur Rd. (upstream from Atchison County Lake) streamgage. Extrapolation of these results across the basin indicated that sediment trapping in farm ponds likely explain little of the difference in sediment yields observed among the three monitoring sites. Farm pond data indicate that less sediment is trapped during large storms and when sediments may remain in suspension when multiple storms occur within weeks or months.

Differences in sediment yields among Atchison and Centralia watersheds may be attributed to some combination of increased channelization, lack of riparian buffers, and less tile drainage in the Centralia basin. Equivalent sediment yields among the Atchison County and Banner Creek watersheds indicate that reference-like sediment yields may be observed in heavily agricultural watersheds through a combination of field-scale management activities and stream channel protection. When computing loads using published erosion rates obtained by single-point survey methodology, streambank contributions from the main stem of Banner Creek are three times more than the sediment load observed by this study at the sediment sampling site at Banner Creek, 2.6 times more than the sediment load observed by this study at the sediment sampling site at Clear Creek (upstream from Atchison County Lake), and are 22 percent of the load observed by this study at the sediment sampling site at Black Vermillion River above Centralia Lake. Comparisons of study sites to similarly sized urban and urbanizing watersheds in Johnson County, Kansas, indicated that sediment yields from the Centralia watershed were similar to those in construction-affected watersheds, while much smaller sediment yields in the Atchison County and Banner Creek watersheds were comparable to stable, heavily urbanized watersheds. Comparisons of study sites to larger watersheds upstream from Tuttle Creek Lake indicate the Black Vermillion River watershed continues to have high sediment yields despite 98 percent of sediment from the Centralia watershed (a headwater of the Black Vermillion River) being trapped in Centralia Lake.

In comparison to upstream data, sediment loading data collected downstream from each impoundment indicated sediment trapping efficiencies of 72, 98, and 98 percent in Atchison, Banner, and Centralia Lakes, respectively. This is because storage volume of Atchison County Lake is less than that of Banner and Centralia Lakes relative to the size of upstream drainage area. 


\section{References Cited}

Abel, P., 2005, Soil survey of Nemaha County, Kansas: Natural Resources Conservation Service, U.S. Department of Agriculture, $242 \mathrm{p}$

Alexander, R.B., Smith, R.A., Schwarz, G.E., Boyer, E.W., Nolan, J.V., and Brakebill, J.W., 2008, Differences in phosphorus and nitrogen deli to the Gulf of Mexico from the Mississippi River basin: Environmental Science and Technology, v. 42, no. 3, p. 822-830.

Broussard, W., and Turner, R.E., 2009, A century of changing land-use and water quality relationships in the continental U.S.: Frontiers in Ecology and Environment, v. 7, no. 6, p. 302-307.

Campbell, H.V., Dickey, H.P., and Rowland, H.T., 1979, Soil survey of Jackson County, Kansas: Soil Conservation Service, U.S. Department of Agriculture, 63 p.

Christensen, V.G., Ziegler, A.C., and Jian, Xiaodong, 2001, Continuous turbidity monitoring and regression analysis to estimate total suspended solids and fecal coliform bacteria loads in real time; in Proceedings of the Seventh Federal Interagency Sedimentation Conference, March 25-29, 2001, Reno, Nevada: Subcommittee on Sedimentation, v. 1, p. III-94 to III-101.

Collins, D.L., and Culbertson, D.M., 1965, A general classification of source areas of fluvial sediment in Kansas: Kansas Water Resources Board Bulletin No. 8, 21 p.

Daugherty, A., and Ingersoll, A., 1954, Fluid mechanics with engineering applications, 5th edition, McGraw-Hill, New York, $472 \mathrm{p}$.

deNoyelles, F., and Jakubauskas, M., 2008, June, Current state, trend, and spatial variability of sediment in Kansas impoundments: Sedimentation in our impoundments: Causes and solutions: Kansas State University Agricultural Experiment Station and Cooperative Extension Service, p. 9-23.

Devlin, D., Nelson, N., French, L., Miller, H., Barnes, P., and Frees, L., 2008, Conservation practice implementation history and trends in the Cheney Lake watershed: AES and CES, Kansas State University, Manhattan, Kans., 8 p.

Duan, N., 1983, Smearing estimates - a nonparametric retransformation method: Journal of the American Statistical Association, v. 78, no. 383, p. 605-610.

Environmental Systems Research Institute (ESRI), 2011, ArcGIS version 9.3.
Food and Agricultural Policy Research Institute (FAPRI), 2008, Evaluating economic benefits of soil and water conservation measures applied in Missouri: University of Missouri, FAPRI-MU Report \#31-07, 37 p.

Gilliom, R.J., and Hamilton, P.A., 2006, Pesticides in the nations streams and ground water, 1992-2001-A summary: U.S. Geological Survey Fact Sheet 2006-3028, $6 \mathrm{p}$.

Gray, J.R., Glysson, G.D., and Edwards, T.E., 2008, Suspended-sediment samplers and sampling methods in Garcia, M., ed., Sedimentation Engineering-Processes, Measurements, Modeling, and Practice: American Society of Civil Engineers, Manual 110, chap. 5.3, p. 320-339.

Guy, H.P., 1969, Laboratory theory and methods for sediment analysis: U.S. Geological Survey Techniques of WaterResources Investigations, book 5, chap. C1, 59 p.

Helsel, D.R., and Hirsch, R.M., 2002, Statistical methods in water resources-hydrologic analysis and interpretation: U.S. Geological Survey Techniques of Water-Resources Investigations, book 4, chap. A3, $510 \mathrm{p}$.

Horizon Systems, 2010, National Hydrography Dataset, accessed 2010, at http://www.horizon-systems.com/ nhdplus/.

Istok, J.D., and Kling, G.F., 1983, Effect of subsurface drainage on runoff and sediment yield from an agricultural watershed in Western Oregon, U.S.A.: Journal of Hydrology, v. 65, no. 4, p. 279-291.

Juracek, K.E., 2011, Suspended-sediment loads, impoundment sediment trap efficiency, and upstream and downstream channel stability for Kanopolis and Tuttle Creek lakes, Kansas, 2008-10: U.S. Geological Survey Scientific Investigations Report 2011-5187, 35 p.

Juracek, K.E., and Ziegler, A.C., 2007, Estimation of sediment sources using selected chemical tracers in the Perry Lake and Lake Wabaunsee Basins, northeast Kansas: U.S. Geological Survey Scientific Investigations Report 20075020, $53 \mathrm{p}$.

Kansas Biological Survey, 2010a, Bathymetric and sediment survey of Atchison County Lake, Atchison County, Kansas: Applied Science and Technology for Impoundment Assessment (ASTRA) Program, Report 2010-04, 16 p.

Kansas Biological Survey, 2010b, Bathymetric and sediment survey of Banner Creek Impoundment, Jackson County, Kansas: Applied Science and Technology for Impoundment Assessment (ASTRA) Program, Report 2010-5, 17 p.

Kansas Biological Survey, 2010c, Bathymetric and sediment survey of Centralia City lake, Nemaha County, Kansas: Applied Science and Technology for Impoundment Assessment (ASTRA) Program, Report 2010-06, 17 p. 
Kansas Data Access and Support Center, 2011, State of Kansas GIS Data Access and Support Center, accessed March 2011, at http://www.kansasgis.org/.

Kansas State University, 2009, var. Land use survey data. Online data, GIS shapefiles accessed from, Kansas Center for Agricultural Resources and the Environment (KCARE), accessed March 2009, at http://www.kwo.org/ impoundments/Sediment_Baseline_Group.htm.

Kansas Water Office, 2009, Sediment baseline assessment work plan, accessed March 2009, at http://www.kwo. org/reservoirs/SedimentGroup/Rpt_Sediment_Baseline_ Assessment_Work_Plan_022009_cbg.pdf

Kennedy, E.J., 1983, Computation of continuous records of streamflow: U.S. Geological Survey Techniques of WaterResources Investigations, book 3, chap. A13, 52 p.

Kennedy, E.J., 1984, Discharge ratings at gaging sites: U.S. Geological Survey Techniques of Water-Resources Investigations, book 3, chap. A10, 59 p.

Lee, C.J., Rasmussen, P.P., and Ziegler, A.C., 2008a, Characterization of suspended-sediment loading to and from John Redmond Impoundment, east-central Kansas, 20072008: U.S. Geological Survey Scientific Investigations Report 2008-5123, 25 p.

Lee, C.J., Rasmussen, P.P., Ziegler, A.C., and Fuller, C.C., 2008b, Transport and sources of suspended-sediment in the Mill Creek watershed, Johnson County, northeast Kansas, 2006-2007: U.S. Geological Survey Scientific Investigations Report 2009-5001, 52 p.

Lee, C.J., and Ziegler, A.C., 2010a, Characterization of sediment transport from urban, urbanizing, and rural watersheds in Johnson County, Kansas 2006-08, The 9th Joint Federal Interagency Sedimentation Conference, June 27-July 1, 2010, Las Vegas, Nevada.

Lee, C.J., and Ziegler, A.C., 2010b, Effects of urbanization, construction activity, management practices, and impoundments on suspended-sediment transport in Johnson County, northeast Kansas, February 2006 through November 2008: U.S. Geological Survey Scientific Investigations Report 2010-5128, 54 p.

National Agriculture Imagery Program (NAIP), 2008, United States Department of Agriculture, Farm Service Agency, Aerial Photography Field Office, accessed 2008 at http://seamless.usgs.gov.

National Oceanic and Atmospheric Administration, 2012, NOAA Satellite and Information Service, (N.C. Center, Producer), accessed 2012, at http://www.ncdc.noaa.gov/oa/ climate/stationlocator.html.
Nolan, K.M., Gray, J.R., and Glysson, G.D., 2005, Introduction to suspended-sediment sampling: U.S. Geological Survey Scientific Investigations Report 20055077, CD-ROM.

Oberg, K.A., Morlock, S.E., and Caldwell, W.S., 2005, Quality assurance plan for discharge measurements using acoustic Doppler current profilers: U.S. Geological Survey Scientific Investigations Report 2006-5079, 18 p.

Porterfield, G., 1972, Computation of fluvial-sediment discharge: U.S. Geological Survey Techniques of WaterResources Investigations, book 3, chap. C3, 66 p.

Putnam, J.E., and Pope, L.M., 2003, Trends in suspendedsediment concentration at selected stream sites in Kansas, 1970-2002: U.S. Geological Survey Water-Resources Investigations Report 03-4150, 36 p.

Rantz, S.E., 1982, Measurement and computation of streamflow: U.S. Geological Survey Water-Supply Paper $2175,631 \mathrm{p}$.

Rasmussen, P.P., Gray, J.R., Glysson, G.D., and Ziegler, A.C., 2009, Guidelines and procedures for computing time-series suspended-sediment concentrations and loads from in-stream turbidity-sensor and streamflow data: U.S. Geological Survey Techniques and Methods, book 3, chap. C4, 54 p.

Rasmussen, T.J., Ziegler, A.C., and Rasmussen, P.P., 2005, Estimation of constituent concentrations, densities, loads, and yields in lower Kansas River, northeast Kansas, using regression models and continuous water quality monitoring, January 2000 through December 2003: U.S. Geological Survey Scientific Investigations Report 2005-5165, 117 p.

Runkel, R.L., Crawford, C.G., and Cohn, T.A., 2004, Load Estimator (LOADEST) - A FORTRAN program for estimating constituent loads in streams and rivers: U.S. Geological Survey Techniques and Methods, book 4, chap. A5, 69 p.

Runkel, R.L., and Hippe, D., 2011, LOADEST: Frequently Asked Questions (FAQ), accessed March 7, 2012, at http://water.usgs.gov/software/loadest/faq/.

Sallee, K.H., and Watts, C.E., 1984, Soil Survey of Atchison County, Kansas: Soil Conservation Service, U.S. Department of Agriculture, $105 \mathrm{p}$.

Sauer, V.B., and Turnipseed, D.P., 2010, Stage measurement at gaging stations: U.S. Geological Survey Techniques and Methods, book 3, chap. A7, 28 p.

Schumm, S.A., 1977, The fluvial system: Wiley, New York, 338 p. 
Sheridan, J.M., Lowrance, R., and Bosch, D.D., 1999, Management effects on runoff and sediment transport in riparian forest buffers: Transactions of the American Society of Agricultural Engineers, v. 42, no. 1, p. 55-64.

Simon, A., and Rinaldi, M., 2000, Channel instability in the loess area of the Midwestern United States: Journal of the American Water Resources Association, v. 36, no. 1, p. $133-150$.

Solinst, 2007, Solinst Levelogger PC software version 4.0.3, at http://www.solinst.com/Downloads/index.html

Stene, E.O., 1946, How lakes came to Kansas: Transactions of the Kansas Academy of Science, v. 49, no. 2, p. 117-137.

The Watershed Institute and Gulf South Research Corporation, 2010, Kansas River Basin Regional Sediment Management Section 204 Stream and River Channel Assessment: The Watershed Institute and Gulf South Research Corporation, $210 \mathrm{p}$.

Trimble, S.W., 1999, Decreased rates of alluvial sediment storage in the Coon Creek Basin, Wisconsin, 1975-93: Science, v. 285, no. 5431, p. 1244-1246.

Turnipseed, D.P., and Sauer, V.B., 2010, Discharge measurements at gaging stations: U.S. Geological Survey Techniques and Methods, book 3, chap. A8, 65 p.

U.S. Army Corps of Engineers, [n.d.], National Inventory of Dams: Accessed February 1, 2011, at http://geo.usace.army. $\mathrm{mil} / \mathrm{pgis} / \mathrm{f}$ ?p=397:12:903104061182741

U.S. Bureau of Reclamation, 1987, Design of small dams (3d ed.): U.S. Bureau of Reclamation, 904 p.
U.S. Environmental Protection Agency, 2009, Kansas' Banner Creek Impoundment Section 319 Nonpoint Source Program Success Story Watershed Management Improves Lake Water Quality: U.S. Environmental Protection Agency 841-F-09-001D, accessed January 2012, at http://www.kdheks.gov/nps/downloads/ks_bannercreek.pdf.

U.S. Geological Survey, 2001, Multi-Resolution Land Characteristics Consortium (MRLC): Accessed 2011, at http://www.mrlc.gov/nlcd2001.php.

U.S. Geological Survey, Kansas Water Science Center Web Page, National Real-Time Water Quality, accessed 2009, at http://nrtwq.usgs.gov/ks/.

Wagner, R.J., Boulger, R.W., Oblinger, C.J., and Smith, B.A., 2006, Guidelines and standard procedures for continuous water quality monitors-site operation, record computation, and data reporting: U.S. Geological Survey Techniques and Methods, book 1, chap. D3, $51 \mathrm{p}$.

Walling, D.E., 1977, Assessing the accuracy of suspendedsediment rating curves for a small basin: Water Resources Research, v. 13, no. 3, p. 531-538.

Walling, D.E., and Gregory, K.J., 1970, The measurement of the effects of building construction on drainage watershed dynamics: Journal of Hydrology, v. 11, no. 2, p. 129-144.

YSI Incorporated, 2010, YSI 6136 turbidity sensor documentation, accessed February 26, 2010, at www.ysi.com/media/pdfs/spec-sheets/E56-6136-TurbiditySensor.pdf.

Zaimes, G.N., Schultz, R.C., and Isenhart, T.M., 2004, Stream bank erosion adjacent to riparian forest buffers, row-crop fields, and continuously-grazed pastures along Bear Creek in central Iowa: Journal of Soil and Water Conservation, v. 59, no. 1, p. 19-27. 
Prepared by the Rolla and Pembroke Publishing Service Centers.

For more information concerning this report, contact:

Office Chief

U.S. Geological Survey

Kansas Water Science Center

4821 Quail Crest Place

Lawrence, KS 66049

dc_ks@usgs.gov

or visit our Web site at:

http://ks.water.usgs.gov 
